\title{
الجراحة التجميلية للنساء من منظور إسلامي
}

$$
\text { أ ـ د. د. ادل عبدالله حمد }
$$

رئيس قسم الثريعة ,كلية العلوم الإسلامية ,جامعة صلاح الدين- أربيل

Email :adil.hamad@su.edu.krd; adil.abdulah@yahoo.com

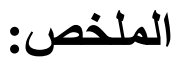

خلق الله تعالى الإنسان في أحسن تقويم، وصوره في أحسن صورة، وفطره على حب الأشياء الجميلة، وحثه على أن يظهر بمظهر لائق وشكل جميل متناسق في المحافل الدينية والأوساط الاجتماعية،

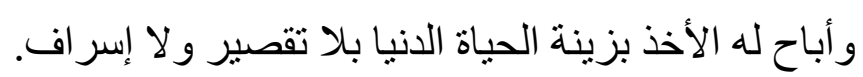

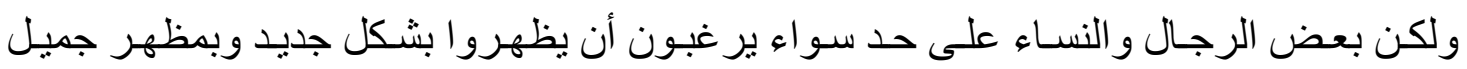

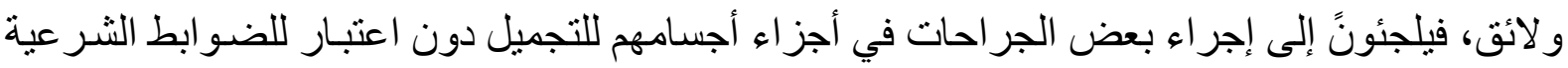
و الأحكام الفقهية، و هذه الجراحات قد تكون ضرورية ونس ونستدعي الحاجة إليها، وقد لا تكون كذلك. و على هذا الأساس فقد اختلف الفقهاء في حكم هذين النوعين من الجراحة التجميلية، فقد ذهب طائفة من العلماء إلى أن الثريعة الإسلامية قامت أحكامها على جلب المصالح، ودرء المفاسد، و المصالح متعلقة بالضرور ات التي ترجع إلى حفظ مقصود من الدقاصد الخمسـة، وهي: (الدين، و النفس، و العقل،

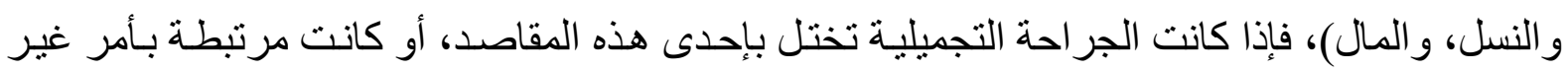

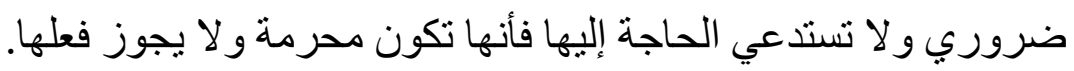

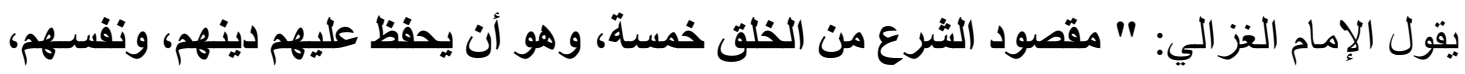

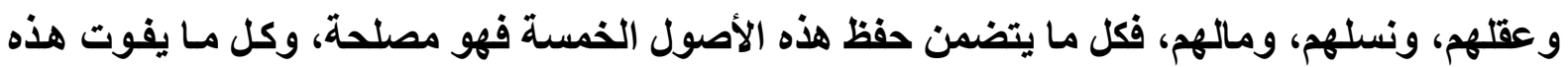
الأصول فهو مفسدة، ودفعها مصلحة" (1). أمسا إذا كانت الجر احة التجميلية لا تختل بمقاصد الثريعة، وكانت ضرورية وتستدعي الحاجة إليها، و لا نولد عنها مضاعفات صحية ونفسية فأنها لا تدخل ضمن نطاق النصوص التي تحردها، وذلك لأن التجميل تحسين، وظهور بمظهر لائق، والإسلام لا ينهى عن ذلك بل يحبذها.

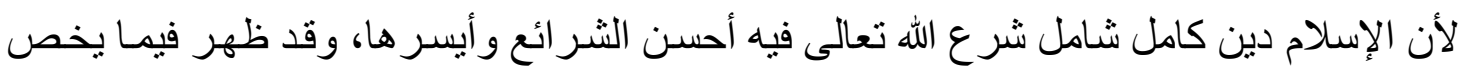
الرجال و النساء في هذا العصر أمور مستحدثة تتعلق بالجر احة التجميلية، وقد تحتم على الفقهاء در استها 
وبيان حكمها، لأنها مسائل شر عية جديدة ومستجدة لم تعرفها سلف هذه الأمة و المجتمعات الإسـلامية من

ولعلَّ مما ينبغي الالتفات إليه أن هذه الظاهرة أصبحت في الآونة الأخيرة منتشرة بين الناس من

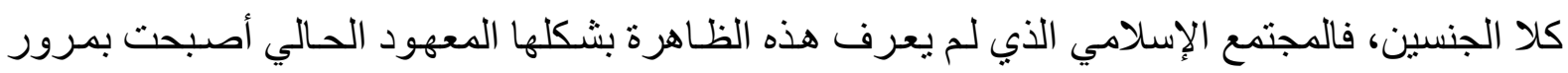

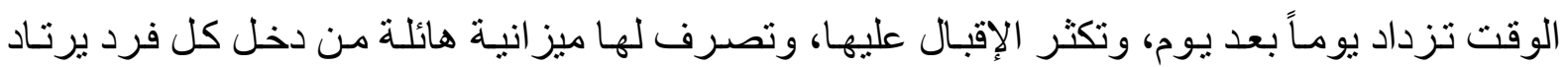

المو اقع التي تقام فيها الجر احة التجميلية.

الكلمات الدالة: الجراحة، التجميلية، النساء، الأحكام الفقهية.

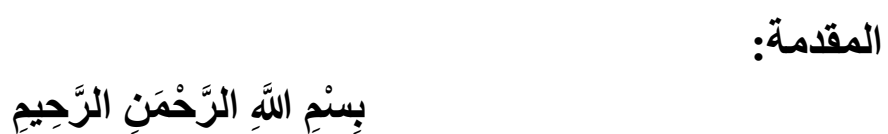

الحمد الله الذي خلق الإنسان من علق، و أنعم عليه بنعمهـ الظـاهرة و الباطنة، و أكرمـه على سائر

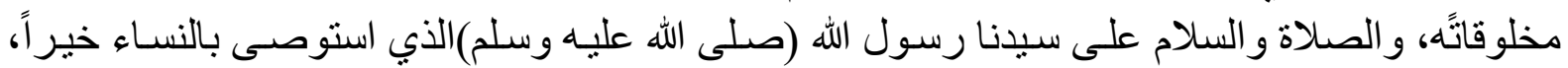
و على آله وصحبه رضوان والهوان الله عليهم أجمعين.

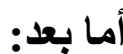

فقد تميزت الثريعة الإسلامية على سائر الأديان لكونها شريعة متكاملة صالحة لكل زمان ومكان،

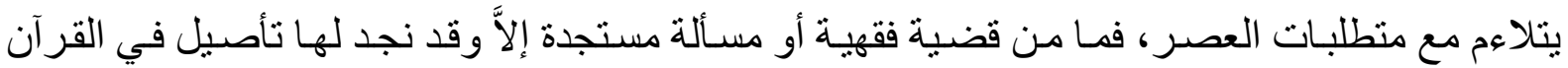

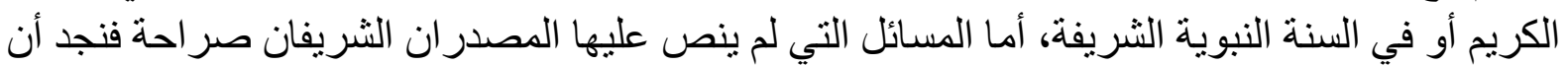
الفقهاء الأجلاء استنبطو ا حكمها الثر عي فئنة النياساً على مثيلاتها.

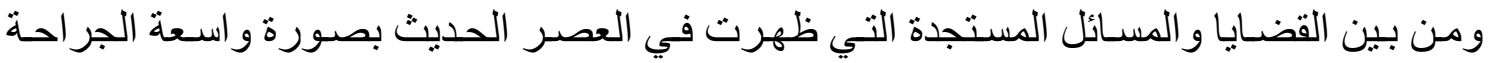

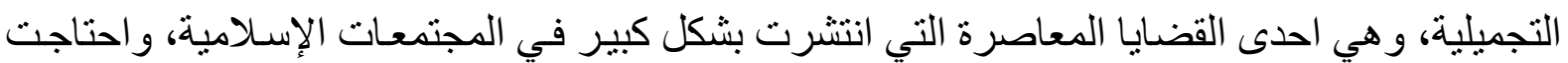

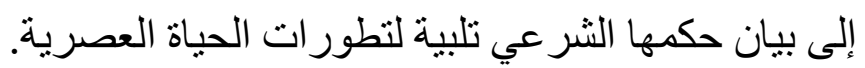

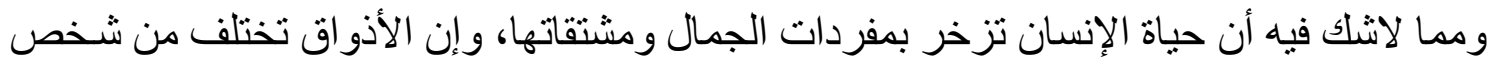

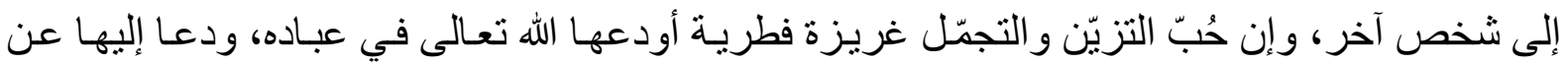

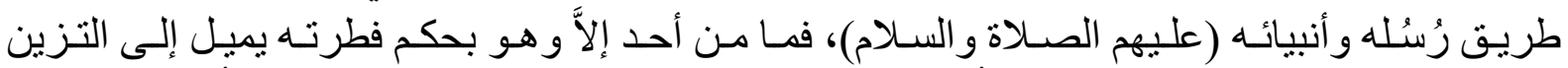

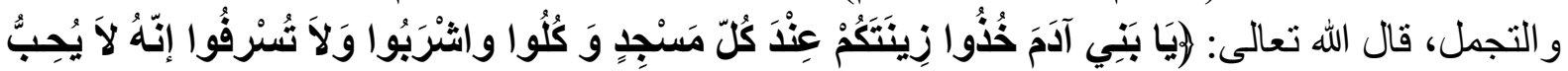

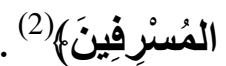

ولكن مما يدعو للأسف ان بعضاً من الناس باسم الدين و الز هد رفضو إ كل مظاهر الجمال وحرموها

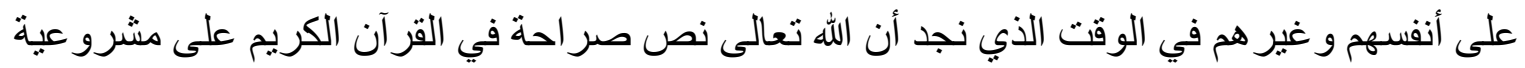




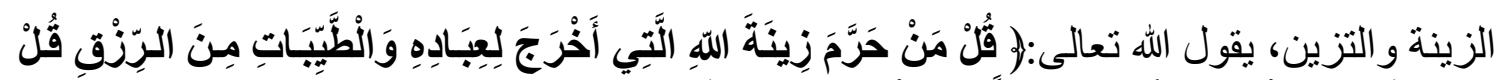

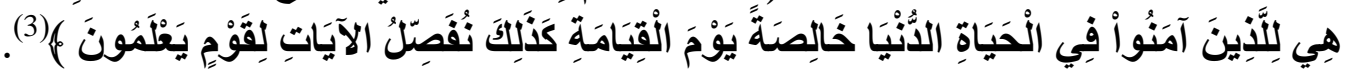

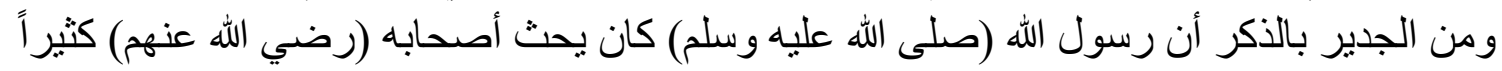

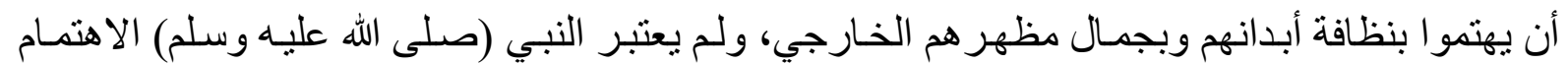

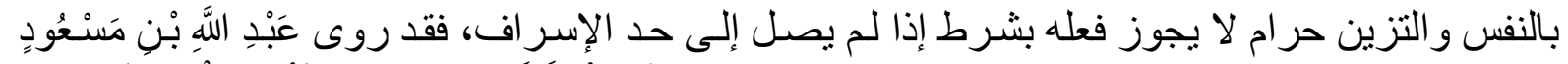

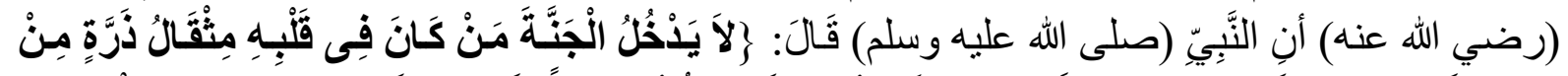

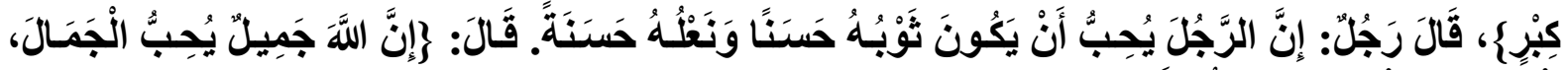

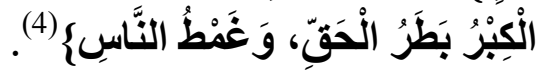

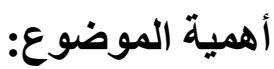

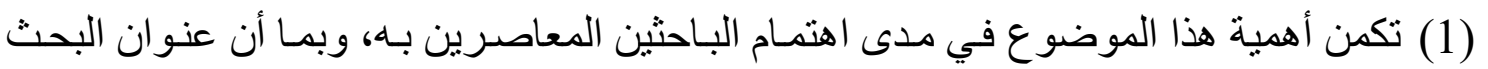

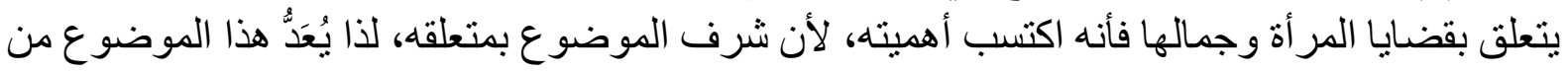

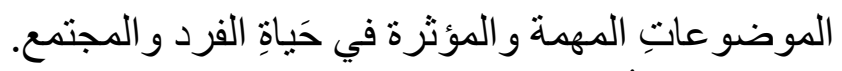

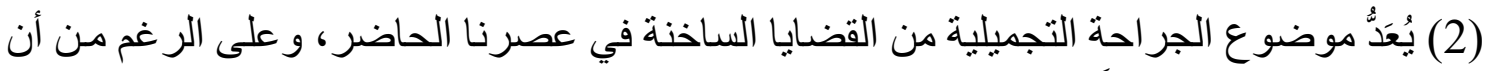

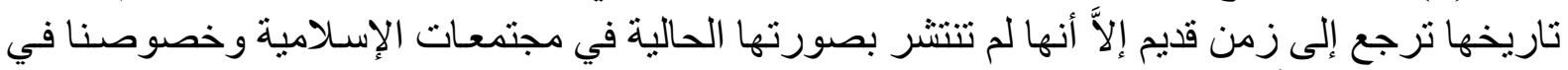

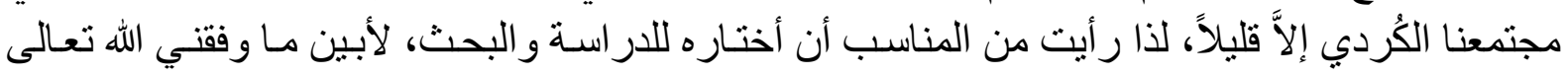

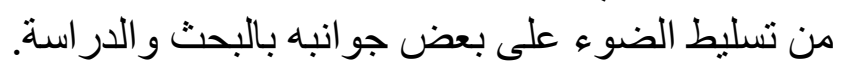

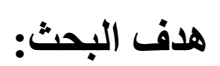

يهدف البحث إلى بيان أقو ال الفقهاء وجهات نظر هم حول الأحكام الفقهية لمسألة الجر احة التجميلية،

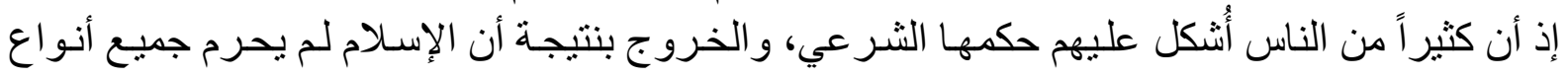
الجر احة التجميلية لذاتها، و إنما حرم بعض منهان النها لآثار المترتبة عليها.

اتبع الباحث في البحث: هذه الدراسة المنهج الاستقر ائي التحليلي وذللك من خلال ما يلي:

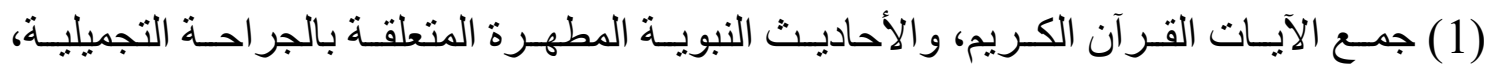

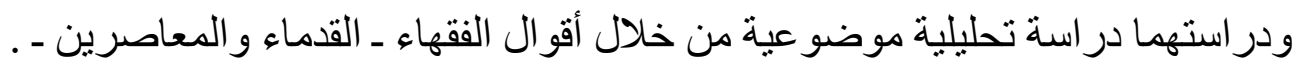

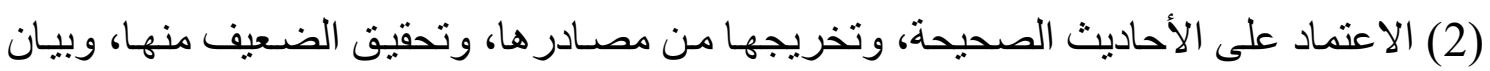
أقو ال أئمة علم الجرح و التعديل فيهاد. شرح المصطلحات و الكلمات الغريبة في الهامش معندماً على المعاجم اللغوية.

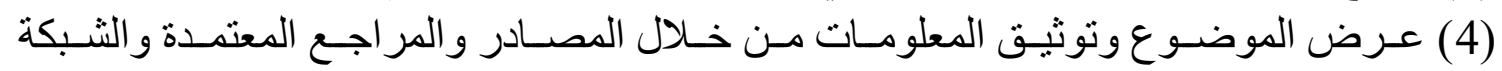

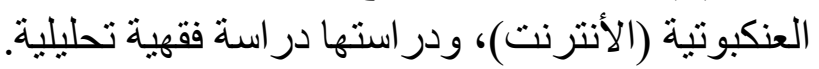
(5) ترجمة الأعلام الواردة في البحث عدا الصحابة الكر ام المشهورين (رضي الله عنهم) بايجاز.

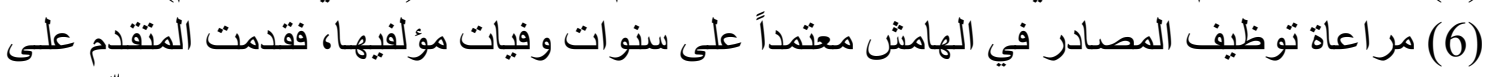

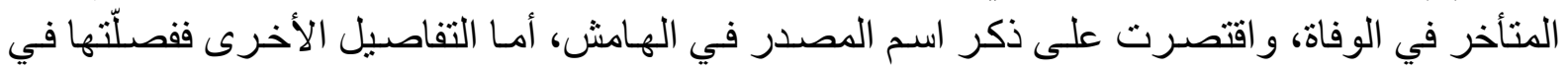


Proceeding of the $2^{\text {nd }}$ Scientific Conference on Women's Health 2-3 September 2020 - Hawler Medical University

الار اسات السابقة:

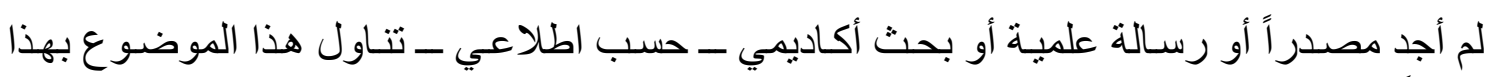
العنو ان، إلآّا أنه هناك در اسات للباحثين المعاصرين تناولو ا فيها الجر احة التجميلية، نذكر منها:

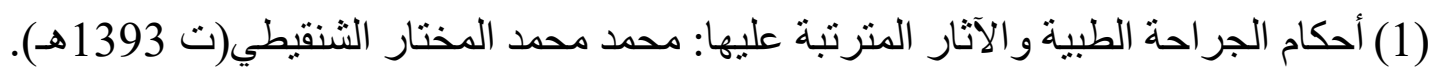

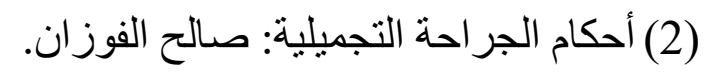
(3) أحكام جر احة التجميل في الفقه الإسلامي: محمد عثمان شبير. (4) الجر احة التجميلية: إيمان بنت محمد عبد التئ الله القنامي. و إلى غير ذلك من المصادر و المر اجع التي اعتمدت عليها في هذا البحث.

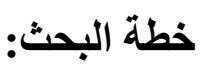

اقتضـت طبيعـة البحث و المـادة العلميـة تقسيمه على مقدمـة وتمهيد ومبحثين، ويمكن ايجـاز خطـة البحث وما يحتويه كالآتي:

ذكرت في التمهيد نبذة تاريخية عن الجر احة التجميلية، وتكلمت من خلاتله أسباب انتشـار الجر احـة

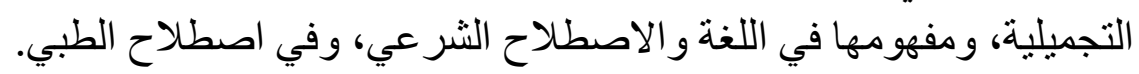

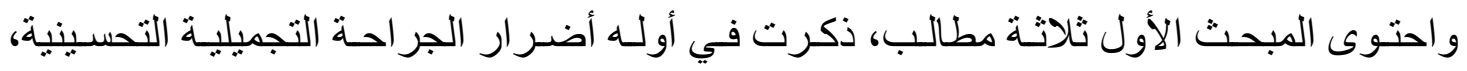

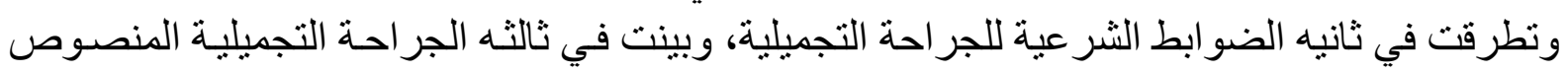

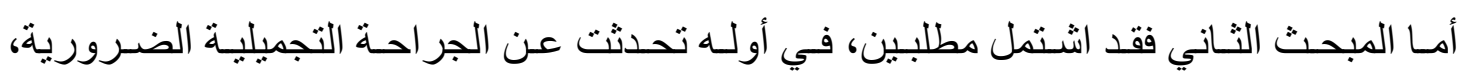
وركزت الدر اسة في ثانيه على الجر احة التجميلية التحسينية وصور ها وحكمها.

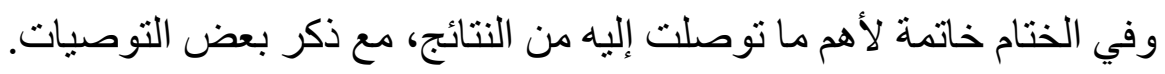

\section{والله ولي التوفيق الباحث \\ تمهيد \\ تاريخ الجراحة التجميلية وأسباب انتشارها}

\section{أولاً: تاريخ الجراحة التجميلية:}

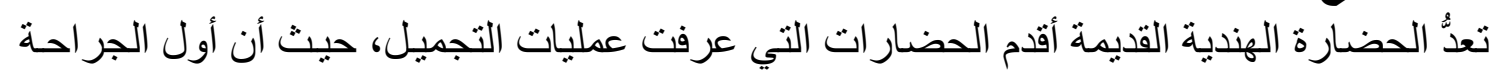

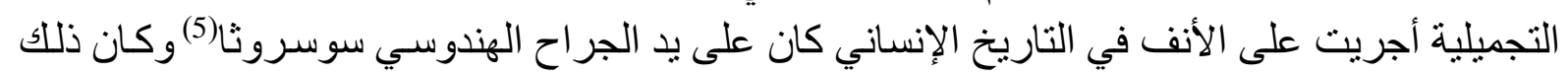

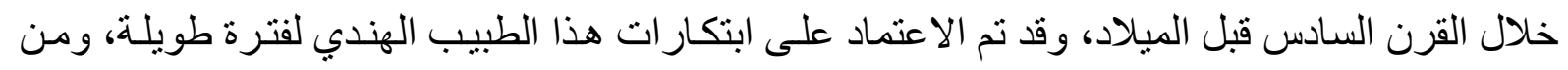

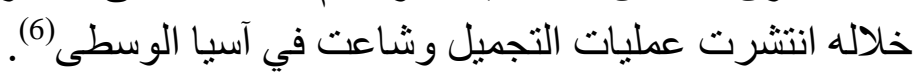

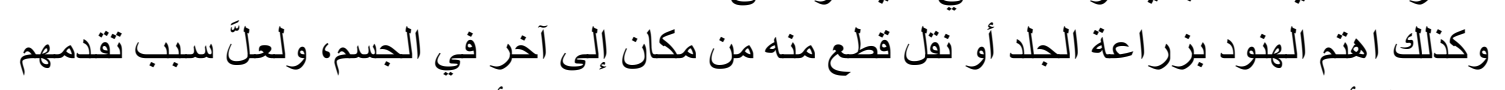

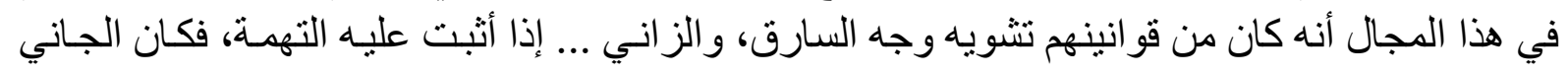

(5) هو: الطبيب و الجر اح الهندوسي سوسروثا، عانش في القرن السادس قبل الميلاد، ويرجع تاريخ أول الجر احسة التجميلية

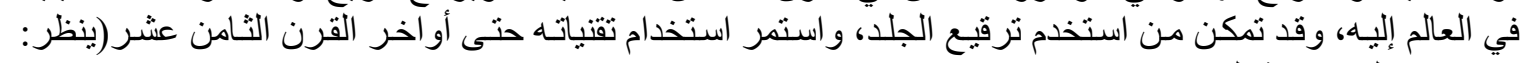

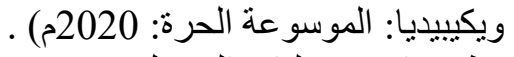
(6) ينظر : تاريخ عمليات التجميل: 2018م. 2020. 
Proceeding of the $2^{\text {nd }}$ Scientific Conference on Women's Health 2-3 September 2020 - Hawler Medical University

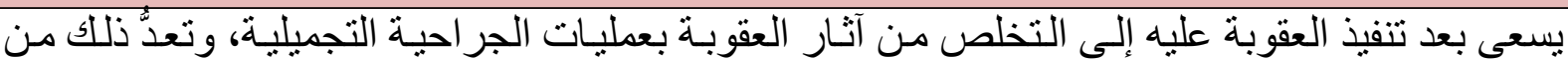

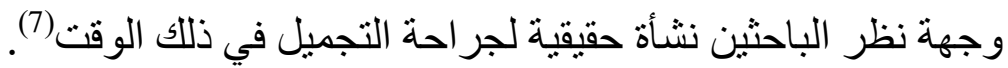

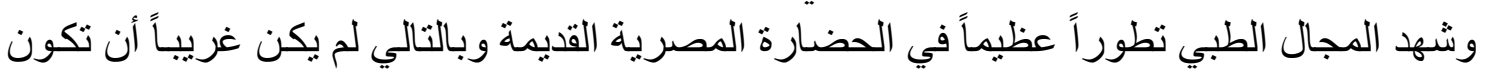

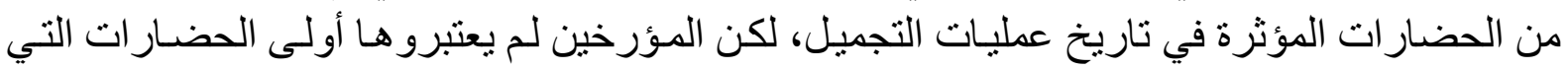
عرفت هذا المجال الطبي على الرغم من أنها سبقت الحضارة الهندية وذلك لعِدة أسباب، من أهمها:

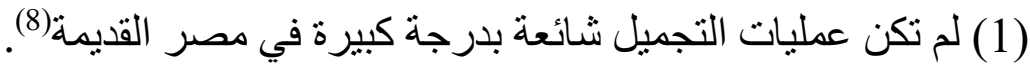

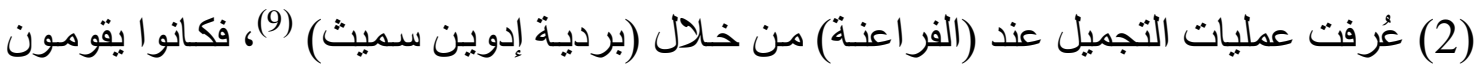
بعمليات شدّ الوجه و إصلاح كسور القك و الأنف (10).

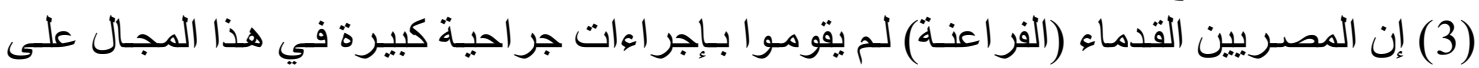

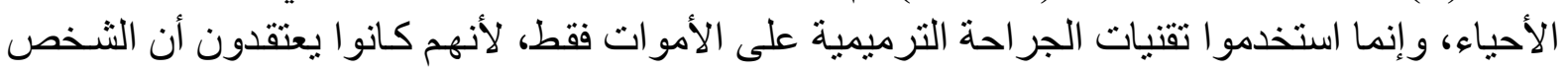
سوف ينظر إلى نفسه في الآخرة كما يفعلوا في هذا العالم، وبالتالي قامو ا ببعض التهاتهات التعديلات لتعزيز سماتهم

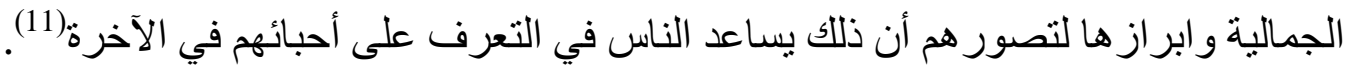

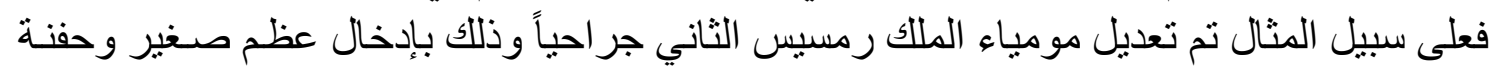
قليلة من البذور داخل الأنف وذلك لضمان عدم تغير أبرز معالم الوجه، ولضمان التعرف وفي عليه في الحيـاة الأخرى حسب معتقداتهم (12). وكذلك وجدت بعض الآثار القديمـة التي ترجع إلى العصر البـابلي، ومن جملتها بعض القوانين

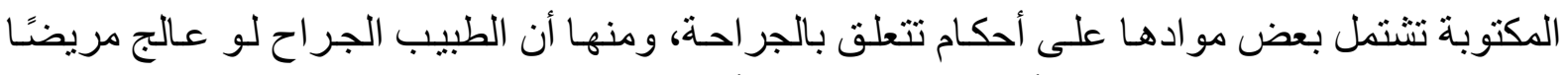

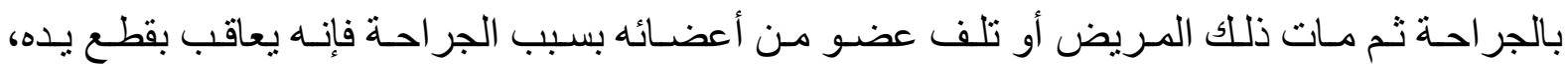

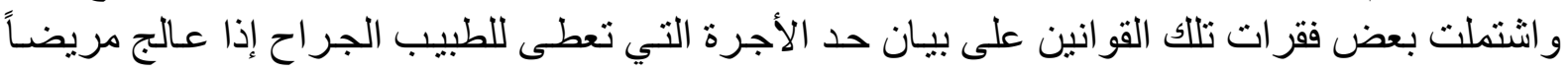

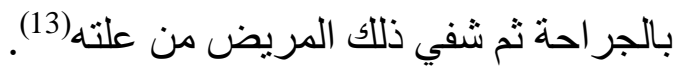
وفي عصر الإغريق نشطت عمليات التجميل بعد أن ازدادت حاجة الناس إليها وبمختلف أنو اعها

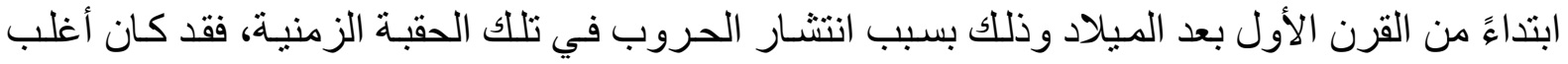

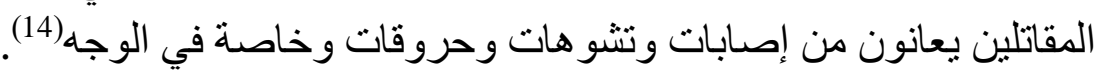

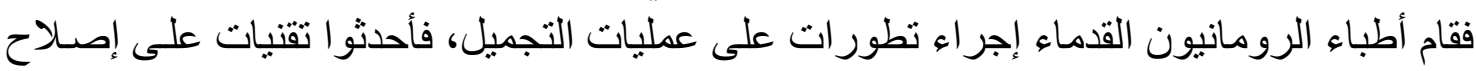

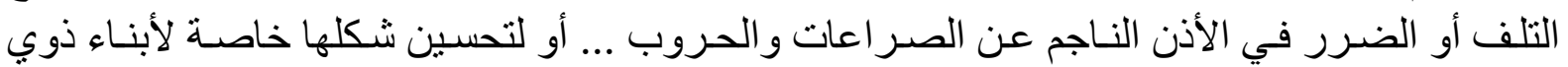

الطبقات العليا(15).

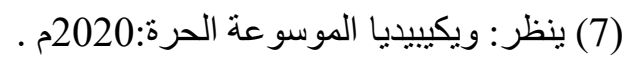
(8) ينظر : تاريخ عمليات التجميل: 2018م. 2018

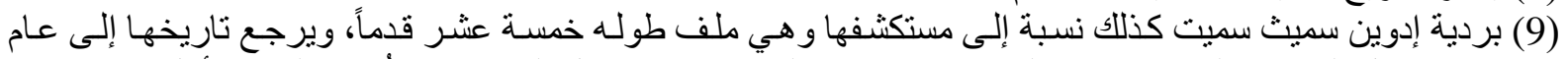

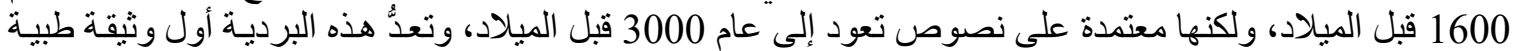

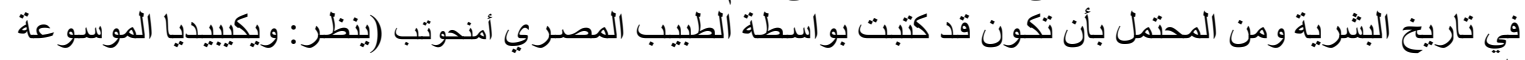

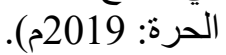

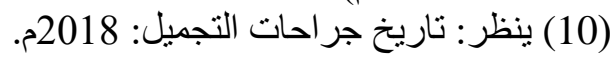

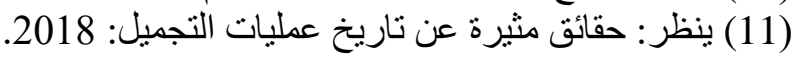
(12) ينظر : ناريخ الجر احة الترميمية و التجميلية: 2014 التئية (13) أحكام الجر احة الطبية و الآثار المترنبة عليها:47.

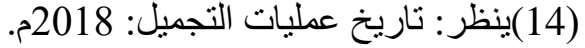
(15) ينظر: تاريخ جر احات التجميل: 2018م. 
Proceeding of the $2^{\text {nd }}$ Scientific Conference on Women's Health 2-3 September 2020 - Hawler Medical University

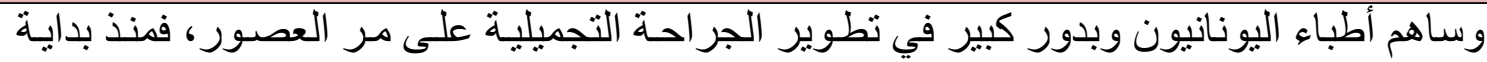
العصر الميلادي عكفوا على البحث عن وسائل إصلاح العيوب الظاهرية وتطوير الآليات المستخدمة فيها

ولما جاء جالينوس(17) اعتنى عناية فائقة بالطب فألف في علم الجر احة الطبية التآليف، وسار عليها الأطباء من بعده، فكان أول من كتب في علم التشريح الذي هو من أهم العلوم التي تعين على فهم الجراحة

وتطبيقها (18).

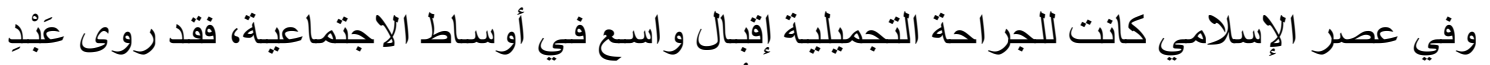

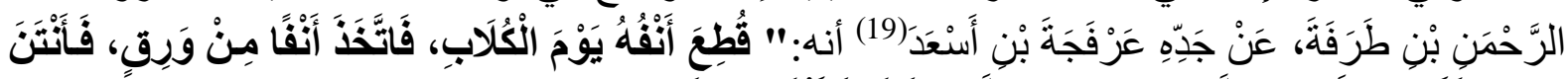

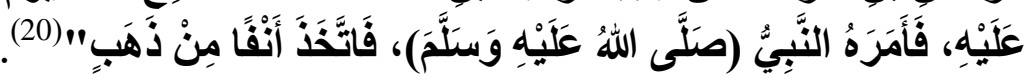

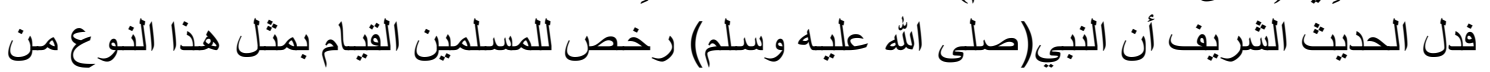

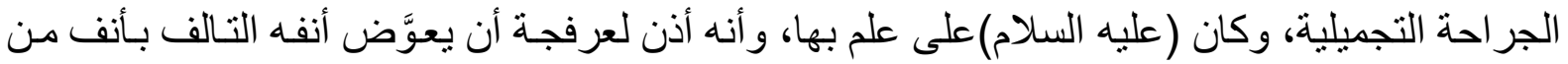

ذهب (21)

و ون الجدير بالذكر أنه برز كثير من الأطباء الجر احين في المجتمع الإسلامي، الذين كان لهم دور

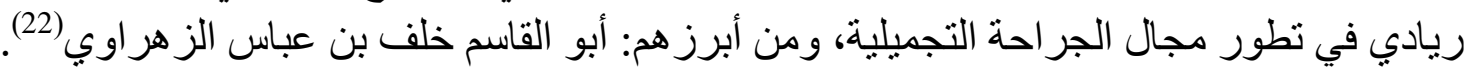

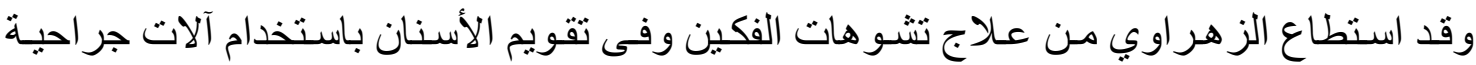

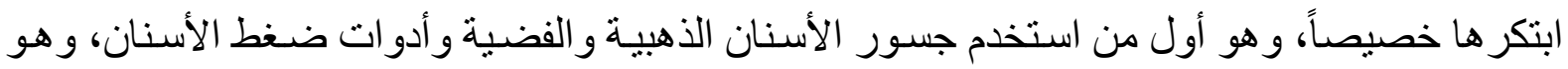

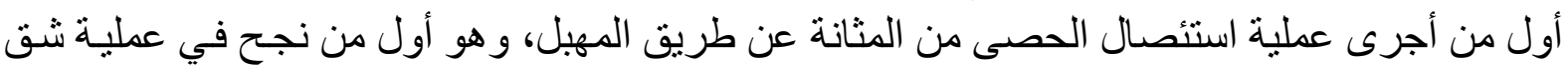
القصبة الهو ائية، كما نجح في إيقاف نزيف الدم بربط الثـر ايين الكبيرة، و علم تلاميذه خياطـة الجروح

خياطة داخلية لا تترك أثر أ مرئياً، وكيفية الخياطة بإبرتين وخيط ونيف احد مثبت بهما (23).

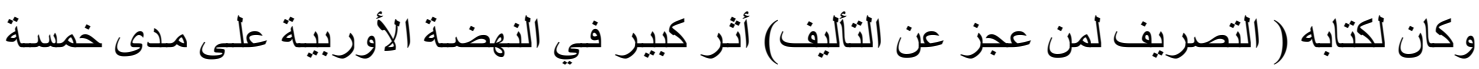
قرون، حيث كان يدرس في جامعات أوروبا، كما كان الجر احون الأوربيون يرجعون إليهر اليه ويقتبسون منـه

وبلغت الجر احة التجميلية في العصر الحديث درجة عالية من الدقة و المهارة و النبوغ الذي لم يسبق له مثيل، وتمكن من تحقيق كثير من الآمال في علم الجر احة، و الذي كانت منذ عهد قريب مئ يعدُّ تحقيقها

(16) (16) هنظر: تاريخ عمليات التجميل: 2018م.

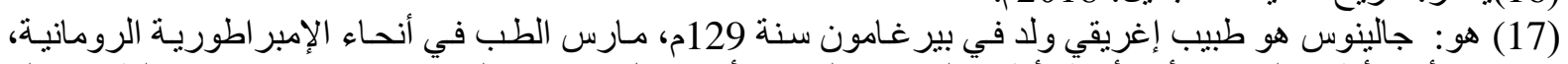

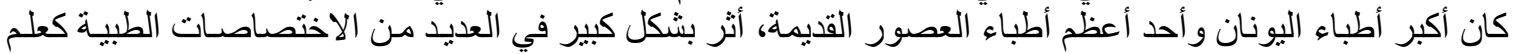

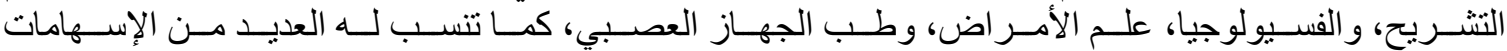

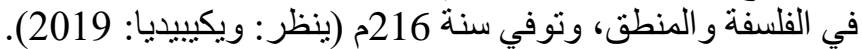

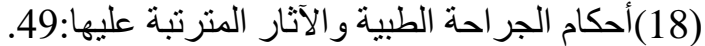

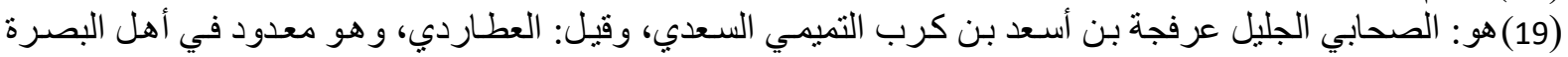

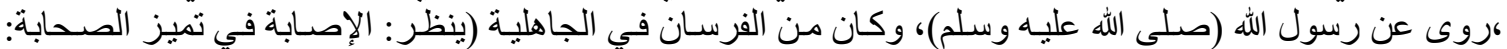

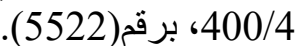

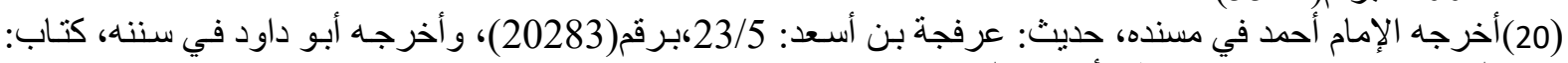

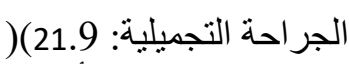

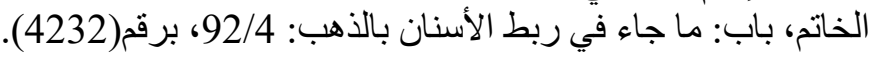

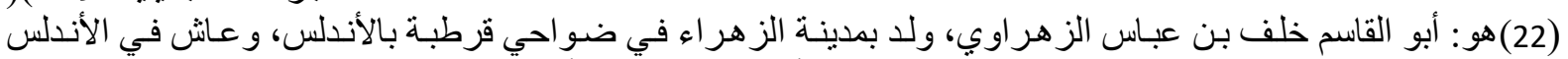
خلال القرن الرابع، نوفي سنة 404هـ (ينظر : عبون الأنباء في طبقات الأطباء:501). 
Proceeding of the $2^{\text {nd }}$ Scientific Conference on Women's Health 2-3 September 2020 - Hawler Medical University

ضرباً من الخيال و المستحيل، ووصل العمل الجر احي إلى أعماق الجسم الإنساني، و إلى أخطر شيء فيهـ وهو القلب و الدماغن(25).

\section{ثنانياً: أسباب انتثار الجراحة التجميلية:}

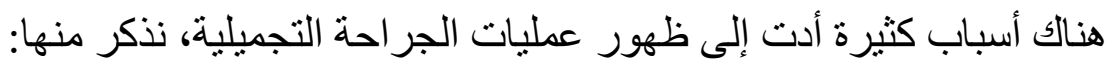

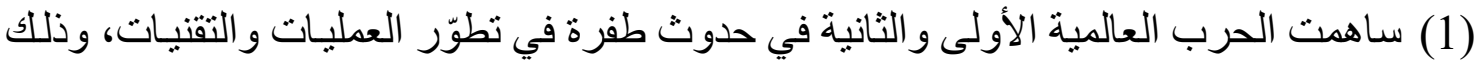

نظر اً لما أصيب به الجنود أثناء الحرب من نشوهات وحروق وتلف في بعض الأعضاء العضاء الخارجية (26)

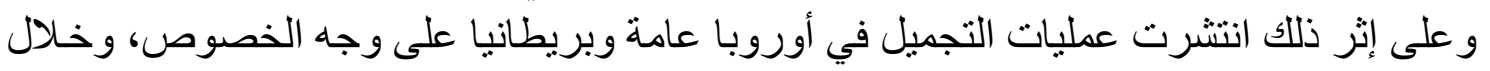

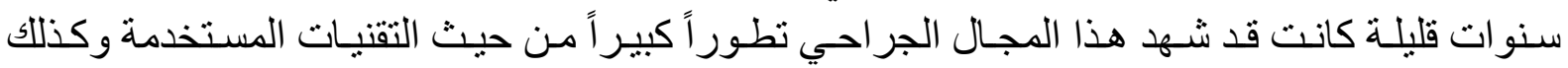

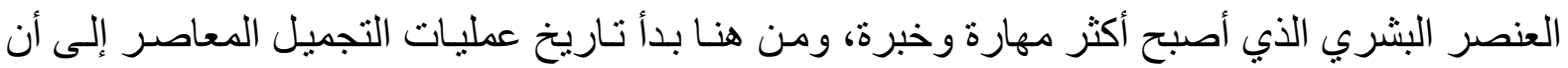
بلغت قمة التطور التقني الذي تشهده حالياً(27).

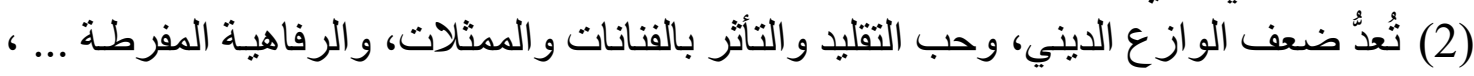

من الأسباب الرئيسية في لجوء كثير من الناس إلى الجر احة التجميلية (28).

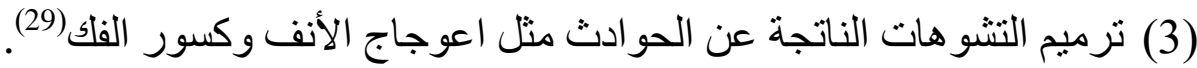

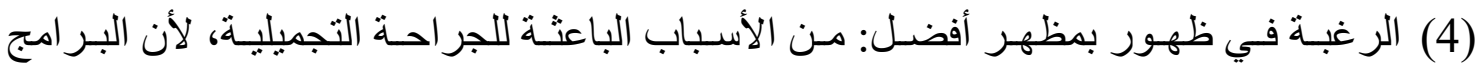

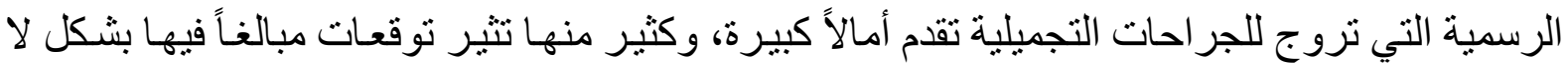
يصدق بالنسبة للإنسان العادي(30). (5) التقة بالنفس: من الأسباب الرئيسية الإقبال على الجراحة التجانية التميلية لزيادة التقة بالنفس وتحسين

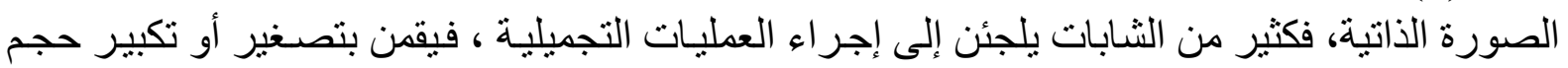
الأنف أو نفخ الثفاه وشدّ الجفون ونفخ الخدين أو بهدف الوصول للقو ام المششوق و المثالي (31).

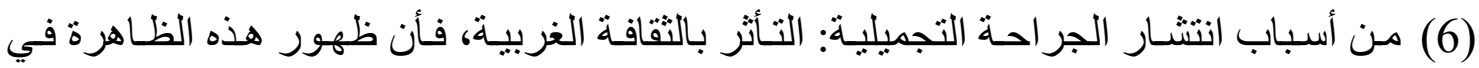

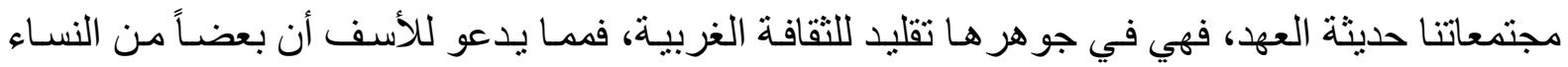

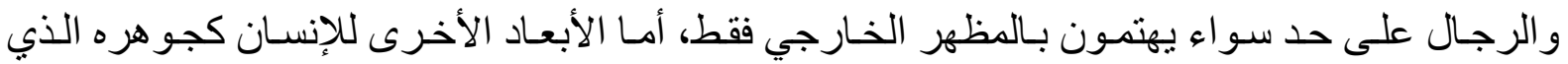

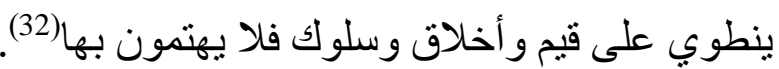
(7) إصلاح الضرر الناجم عن علاج أمر اض كالأور ام السرطانية مثل استنئصال الثذي حيث تلجأ

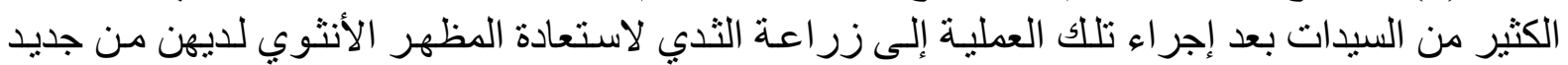

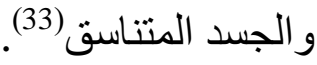

\section{ثالثاً: تعريف الجراحة التجميلية في اللغة والاصطلاح:}

\section{(1) تعريف الجراحة في اللغة والاصطلاح:}

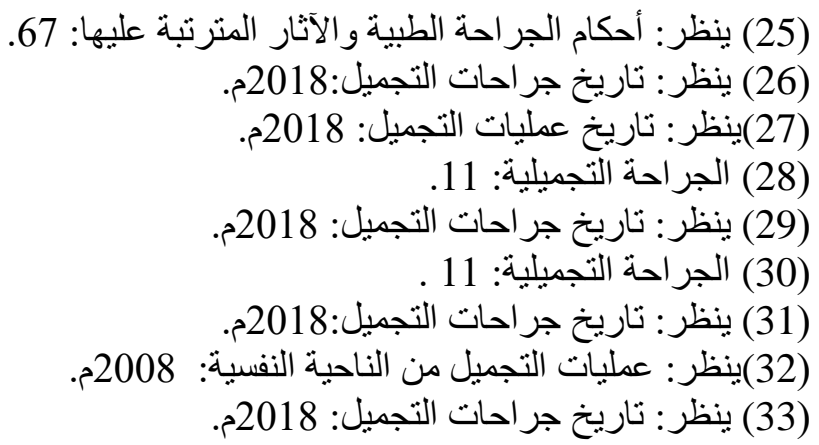


Proceeding of the $2^{\text {nd }}$ Scientific Conference on Women's Health 2-3 September 2020 - Hawler Medical University

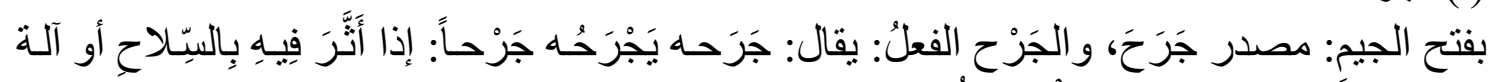

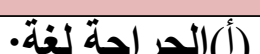

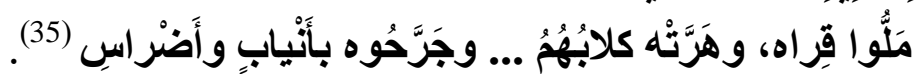

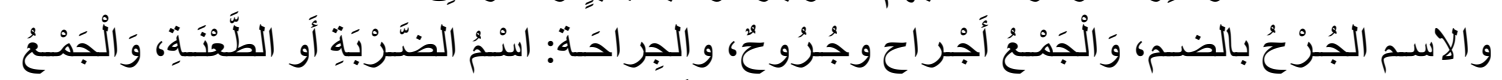

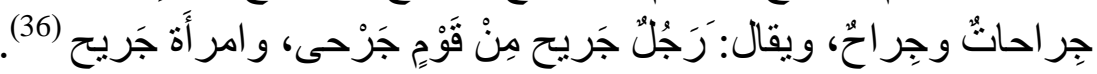

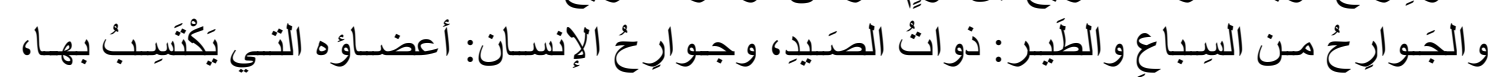

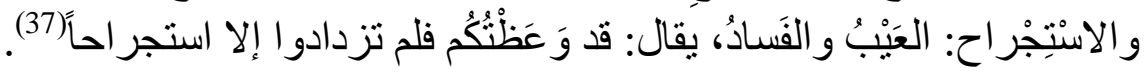

\section{(ب) (الجراحة اصطلاحاً:}

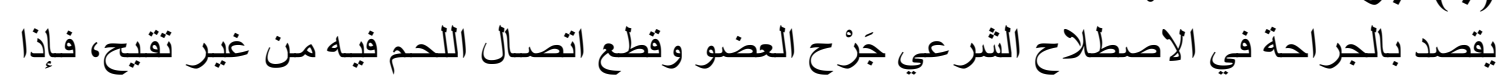

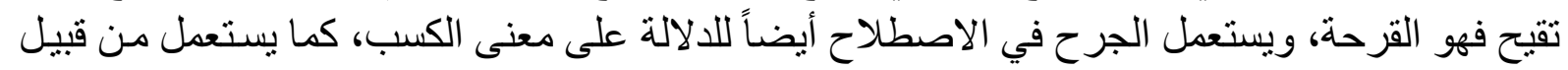

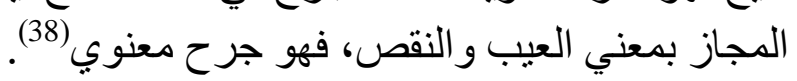
(2) تعريف التجميل لغة واصطناحاً: فهراً

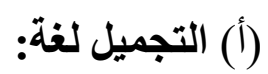

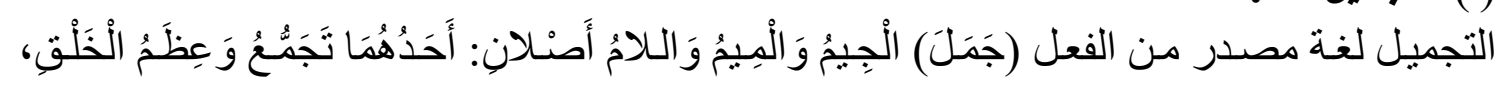

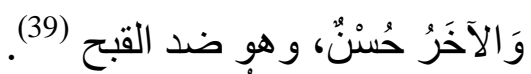

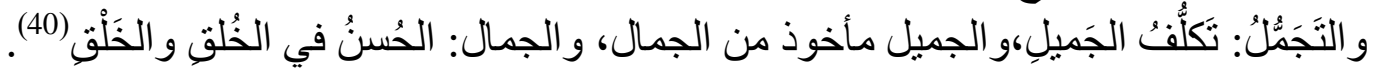

\section{(ب) التجميل اصطلاحاً:}

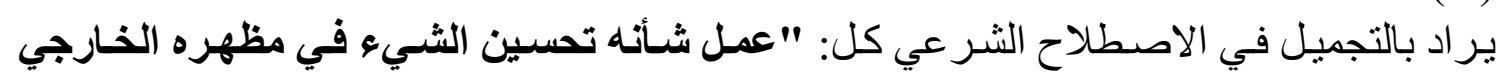

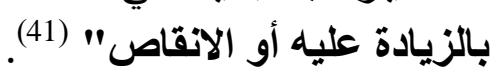

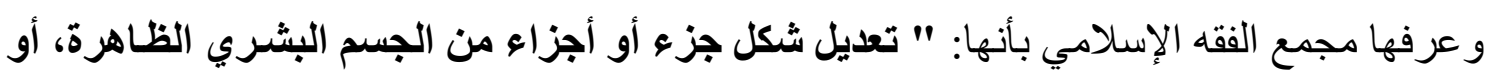
إعادة وظيفته إذا طرأ عليه خلل مؤثر الفي بانها:

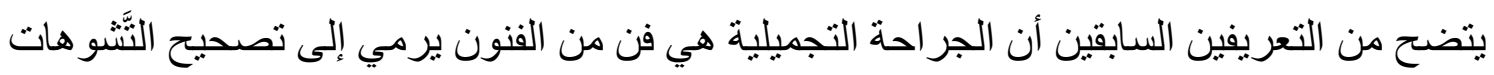

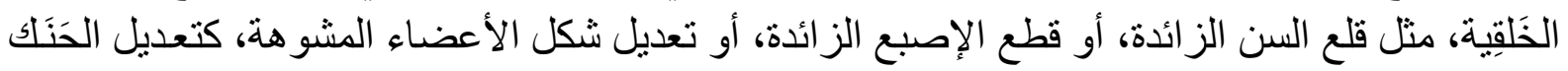

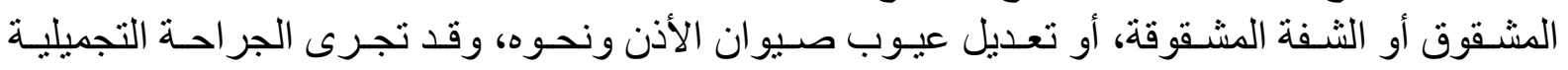

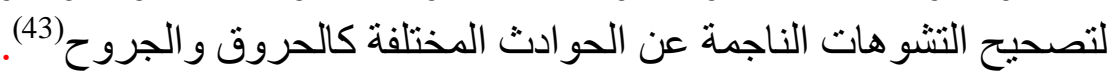

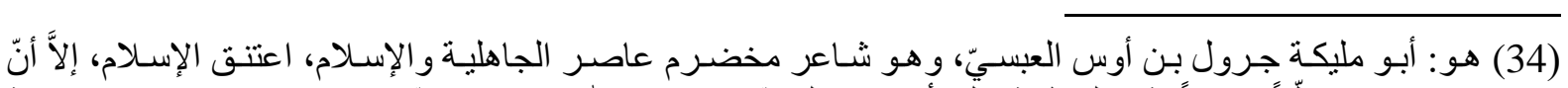

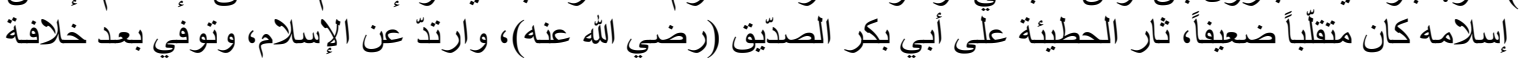
معاوية(بنظر: (الثعر و الثعر اء : (310/1). (35) (36) ديو انه: 2.

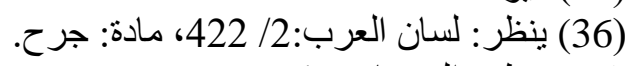

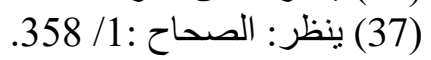

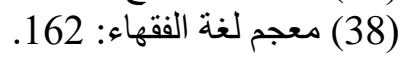

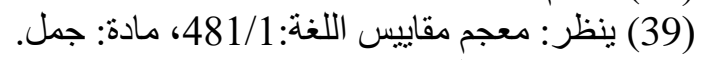

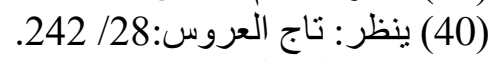
(41) (42) معجم لغة الفقهاء: 122. (42) قرار مجمع الفقه الإسلامي الدولي الدورة: (18) (18)، سنة: 2007مة 2007م.

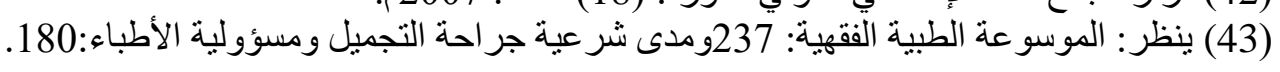


Proceeding of the $2^{\text {nd }}$ Scientific Conference on Women's Health 2-3 September 2020 - Hawler Medical University

(3) التجميل في اصطلاح الأطباء:

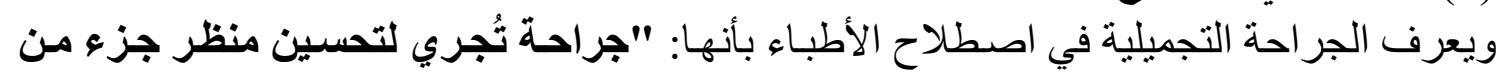

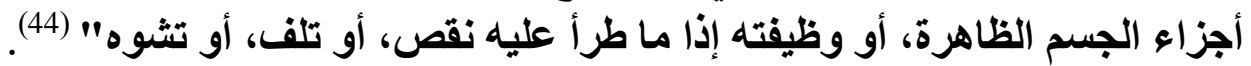

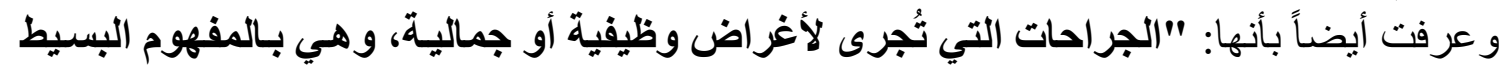

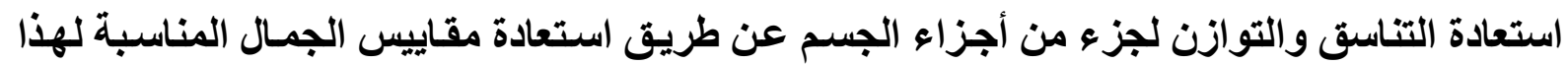

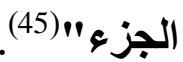

ويبدو من التعـاريف السـابقة أن المـر اد بالجر احـة التجميليـة العمليـات التي تُجرى على على المظهر

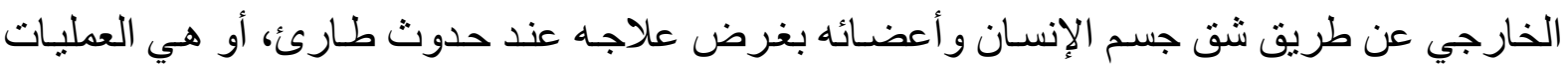

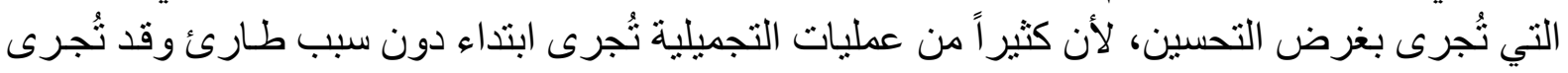

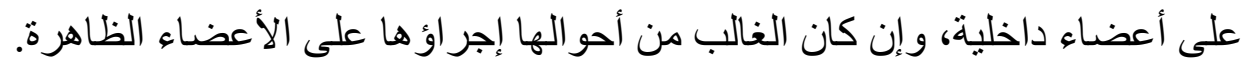

\section{المبحث الأول}

\section{أضرار الجراحة التجميلية وضوابطها}

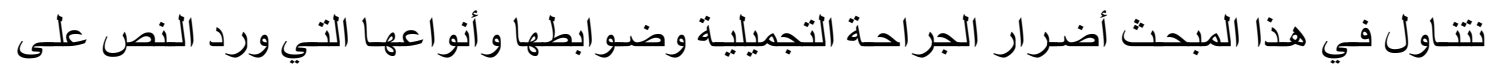
مشرو عيتها و عدمها نذكر ها في ثلاثة مطالب كالآتي:

\section{المطلب الأول \\ أضرار الجراحة التجميلية التحسينية الإلية}

أن للجر احة التجميلية التحسينية أضرار شر عية وطبية كثيرة، نذكر بعض الجية منها كالآتي:

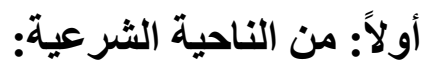

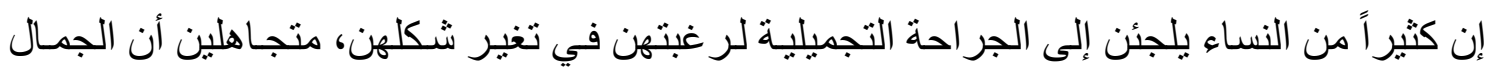

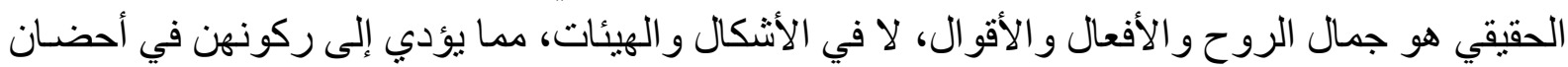

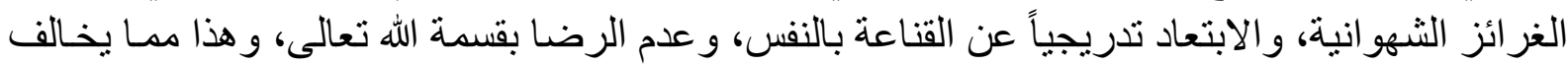

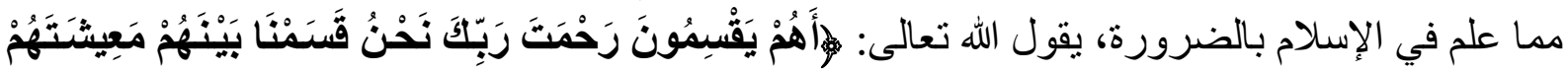

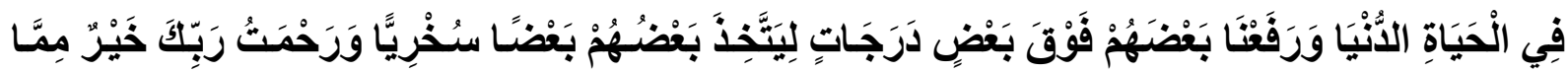

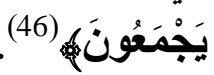

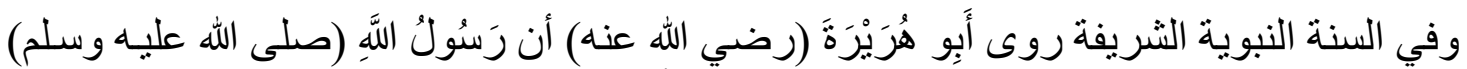

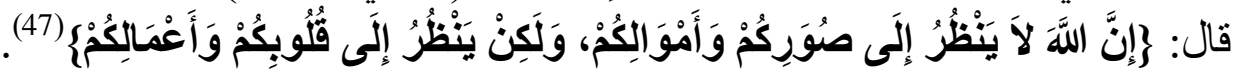

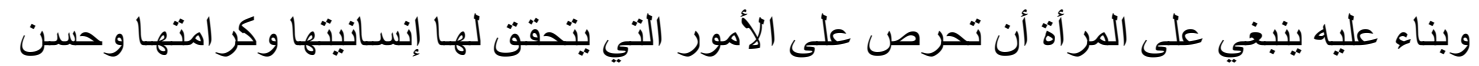

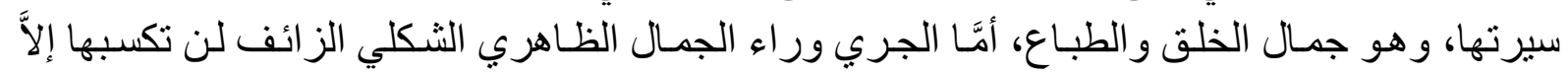
الانطلاق في طريق الثهوات و الغرائز الذبي لا يُشبع أبداً.

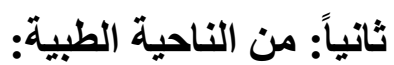


Proceeding of the $2^{\text {nd }}$ Scientific Conference on Women's Health 2-3 September 2020 - Hawler Medical University

\section{إن للجر احة التجميلية التحسينية أضر ار كبيرة من الناحية الطبية، نذكر منها:}

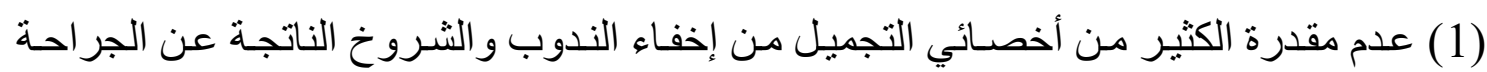

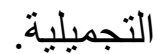

(2) فثنل الكثير من الأخصائيين من وقف النزيف الدموي الناتج عن الجراحة، وظهور بعض

الأورام الدموية الناتجة عنها.

(3) تغيير في لون الجلد في كل المنطقة التي أجريت فيها العملية وخصوصاً للى إجر اء جر احات تجميل تصغير أو تكبير حجم الصدر.

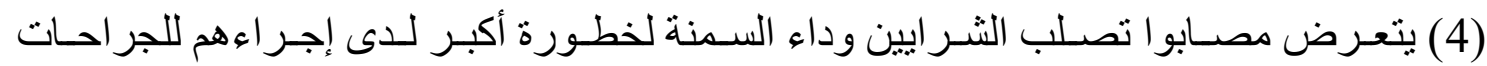

التجميلية (48).

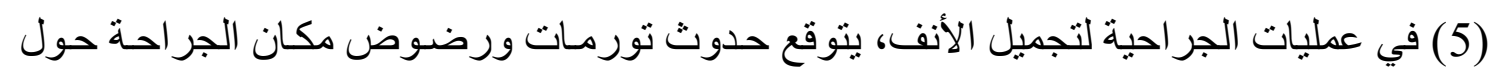

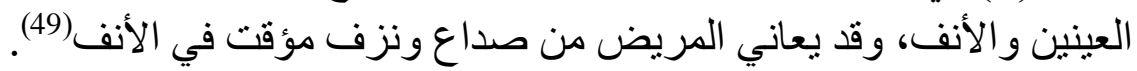

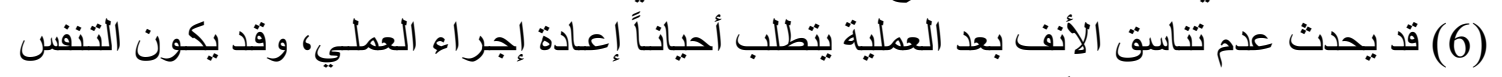
عن طريق الفم لمدة طويلة، وأحياناً تظهر بقع داكنة سوداء حول بنف العين بعد العملية(50).

\section{المطلب الثاني \\ الضوابط الثرعية للجراحة التجميلية}

ذكر الفقهاء ضو ابط شر عية عدة يجب توفر ها في الجر احة التجميلية الطبية حتى يحكم بجوازهـا، وفيما يأتي نذكر بعض منها كالآتي:

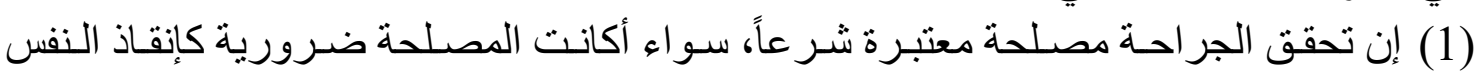

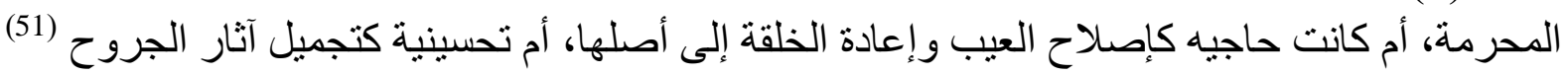
(2) ألا يترتب على الجراحة ضرر يربو على المصلحة المرتجاة من الجراحة، ويقرر هذا الأمر أهل الاختصاص الثقات (52).

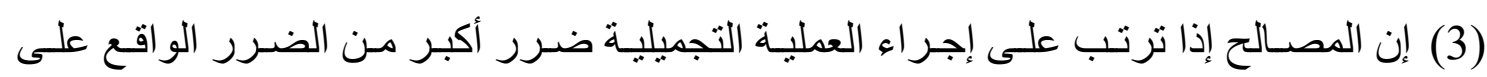

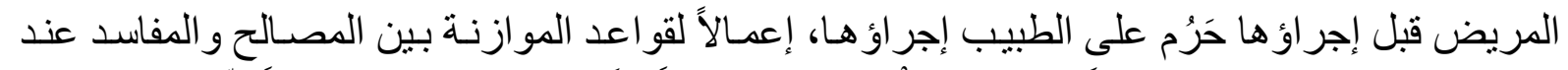

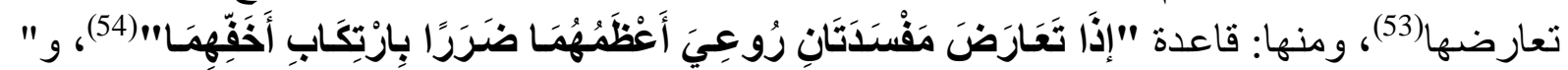

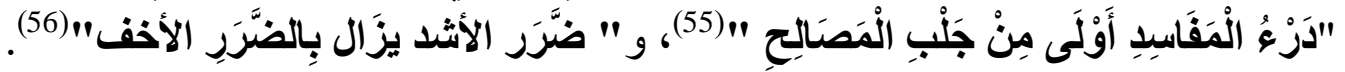

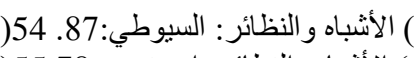
(48)(أنو اع العمليات التجميلية أساليبها وأضر ارها: 2015م. (49)(المصدر نفسه: 262 (48) (50) زينة المر أة المسلمة و عمليات التجميل: 109.

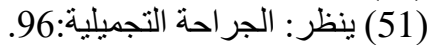

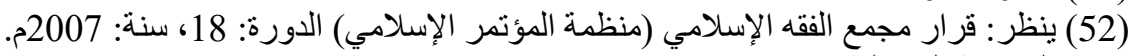

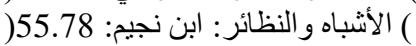

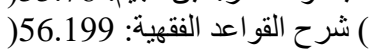


Proceeding of the $2^{\text {nd }}$ Scientific Conference on Women's Health 2-3 September 2020 - Hawler Medical University

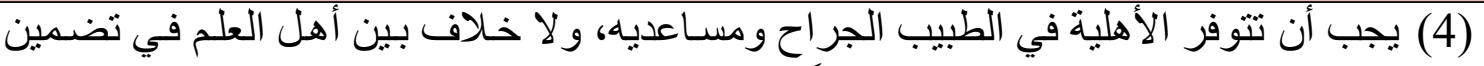

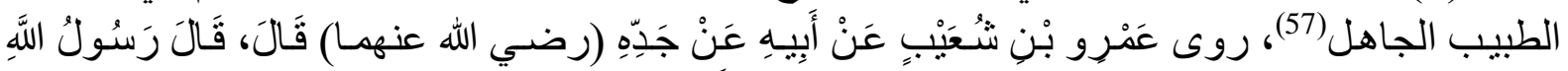

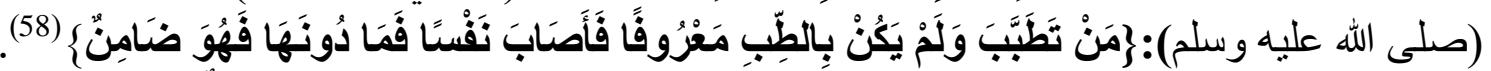

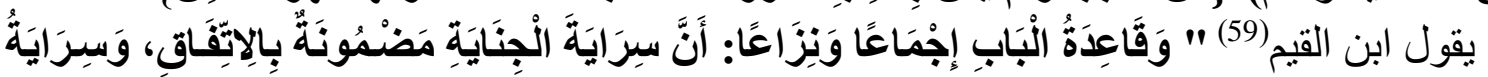

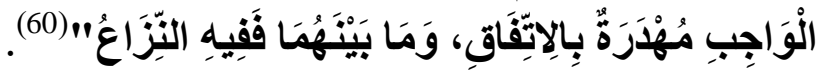

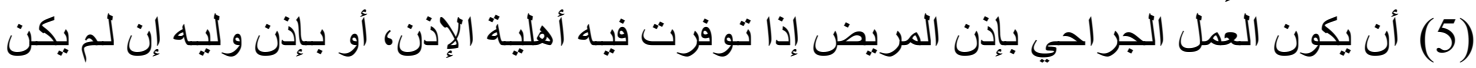

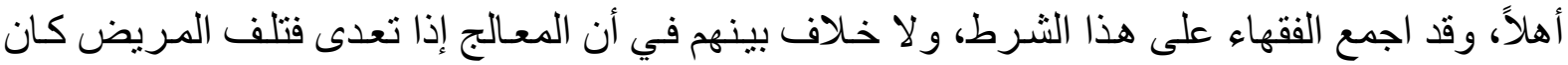

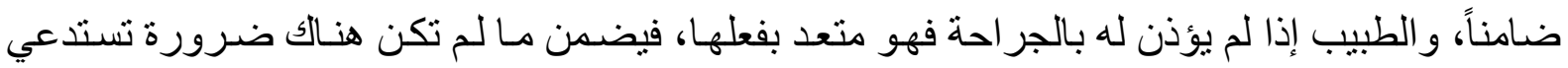

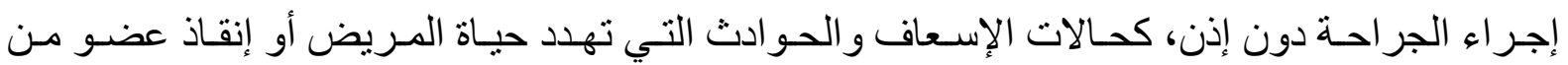
أعضائه(61)

(6) ألا يوجد البديل الذي هو أخف ضـررًا مـن الجراحة، فـإن وجد بديلاً للجر احة اخف ضـرراً، كالعقاقير والأدوية لزم المصبر إليه صيانة لأرواح الناس (62).

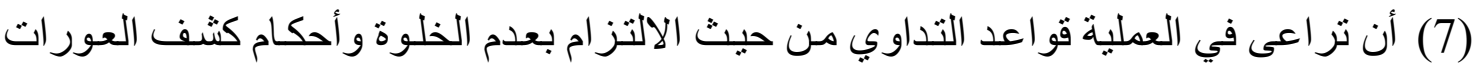

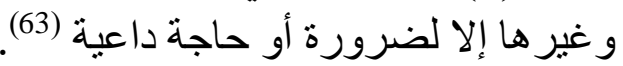

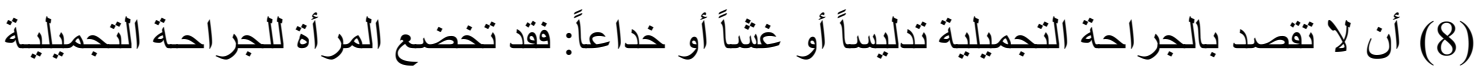

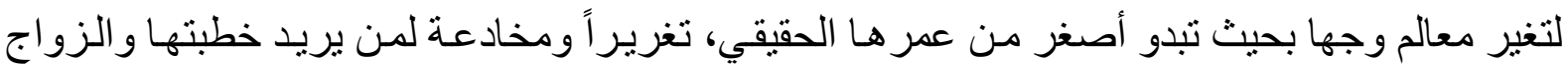

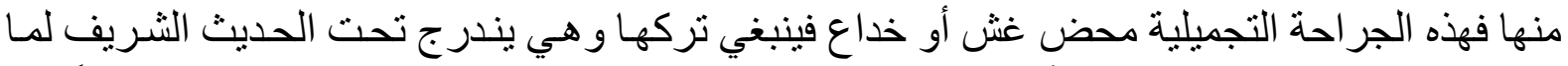

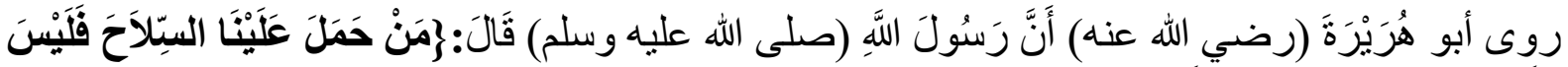

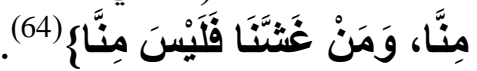
ولكن إذا أر ادت بذللك إرضاء لزوجها فئا وبدت أكثر جمالاً وشباباً فلا باس في ذلك لأن هذه الزينـة لا تغرير فيها ولا غش، لأن الزوج يعرف حقيقتها (65).

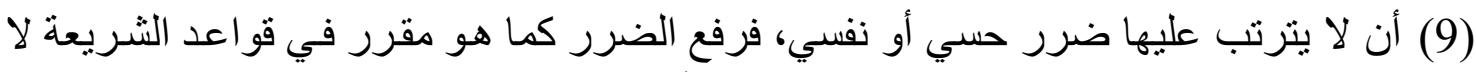

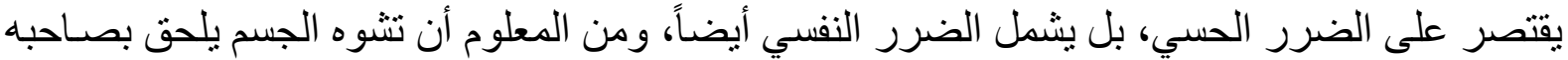

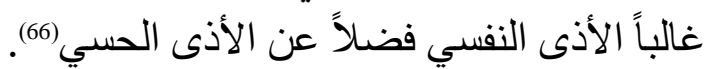

(10) لا يجوز إجر اء الجر احة التجميلية التحسينية التي لا تدخل في العلاج الطبي، ويقصد منها لاديا

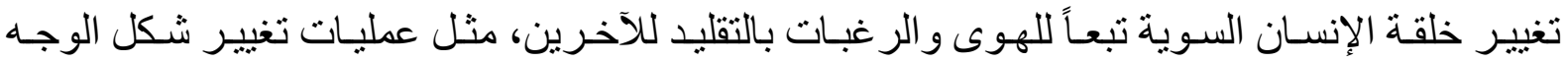

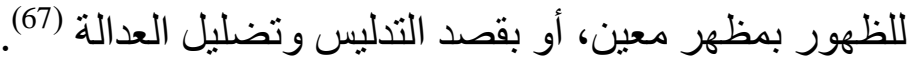

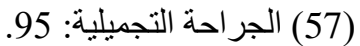

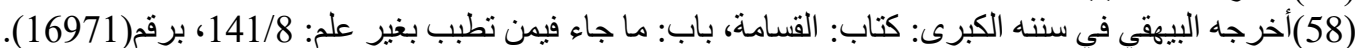

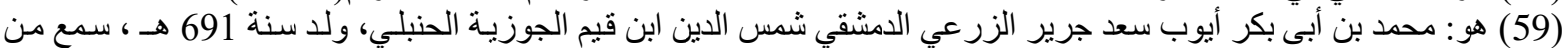
ابن تيمية، له مؤلفات كثيرة في مختلف العلوم الإسلامية ، نوفي سنة الزئة 751 هـ (ينظر : البدر الطالع: 143/2).

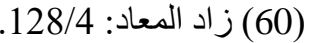
(61) الجراحة التجميلية: 94 وقرار مجمع الفقه الإسلامي (منظمة المؤتمر الإسلامي) الدورة :18، سنة: 2007م.

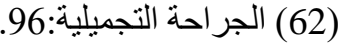

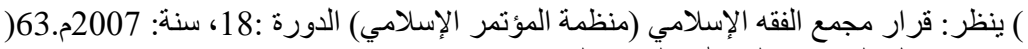

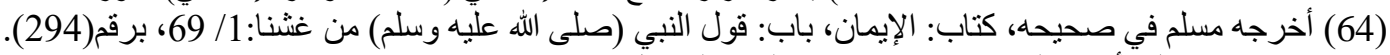
(65) ينظر : زينة المر أة في الثريعة الإسلامية و عمليات التجميل: 42 الإنيان 
Proceeding of the $2^{\text {nd }}$ Scientific Conference on Women's Health 2-3 September 2020 - Hawler Medical University

(11) أن لا تكون في الجر احة تغيير لخلق الله تعالى، كتغيير الجسم أو بعض أعضائه لطلب زيادة

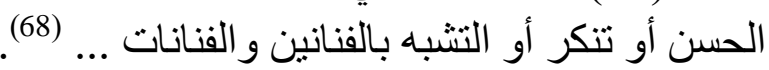

\section{المطلب الثالث}

\section{الجراحة التجميلية المنصوص عليها}

تنقسم الجر احة التجميلية التي ورد النص عليها في الثريعة الإسلامية على قسمين، و هما: أولاً: الجراحات التجميلية المشروعة: وتشمل هذا القسم من الجر احة التجميلية الأنواع الآتية:

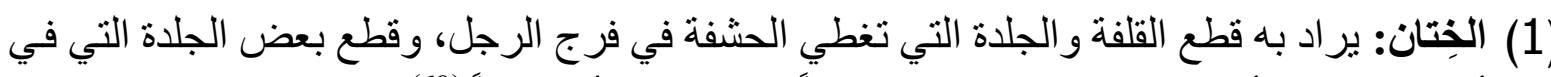

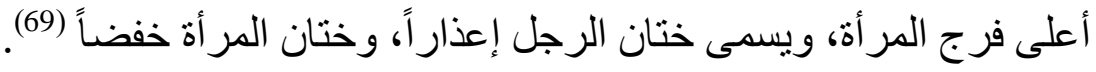

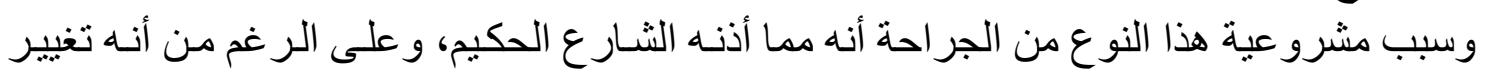
خلق الله تعالى ولكن فيه فو ائد صحية كثيرة ولهذا أجازه الإسلام (70)، فالختان من عندام التهام الحنيفية ملة إبر اهيم

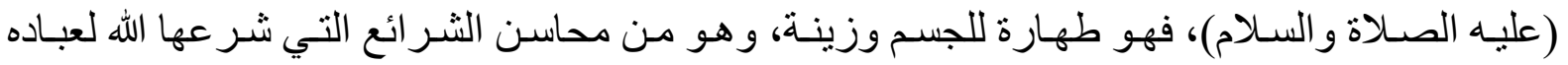
الذكور(71)، فضلاً عن فو ائد الختان الطبية التي أوضحها فئ الأطباء (72).

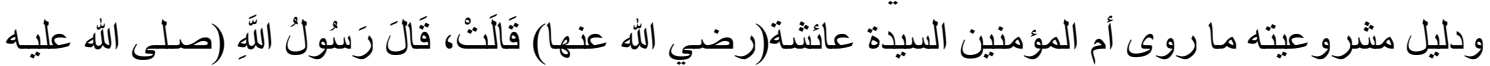

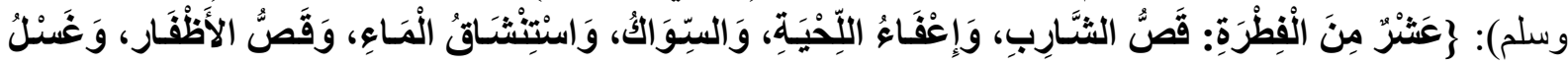

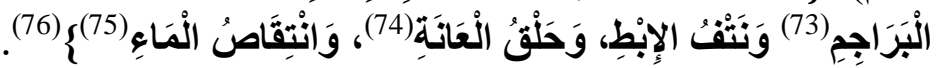

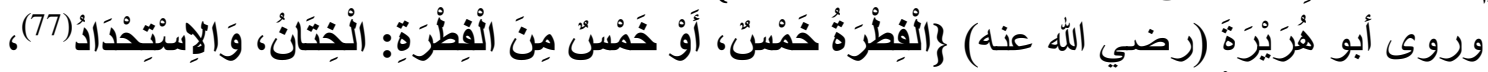

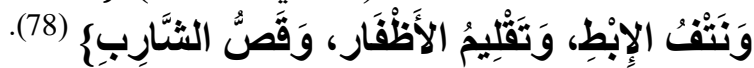
(2) ثقب الأذن (79): المر اد بـه تحسين مظهر الأذن وتحقيق شكله نحو الأفضل، وتجري للصنغار و الكبار على حد سو اء (80).

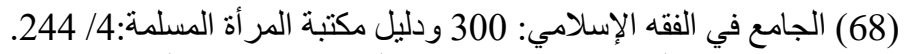

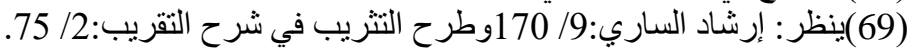

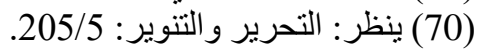

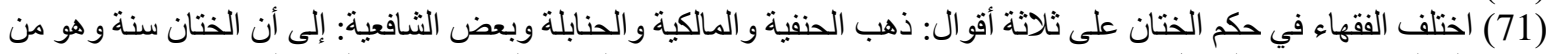

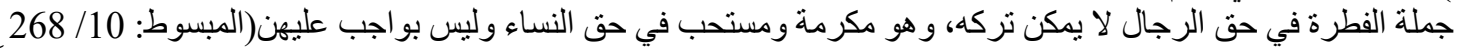

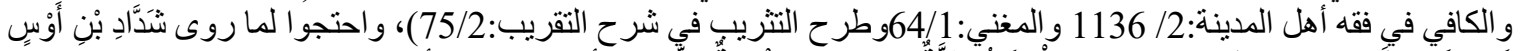

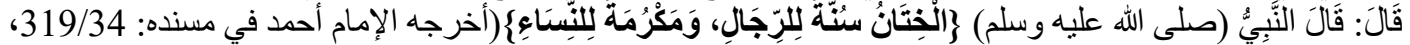

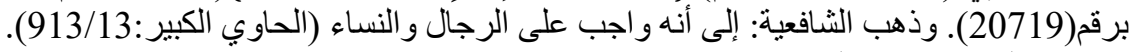

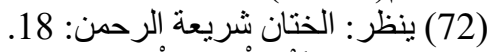

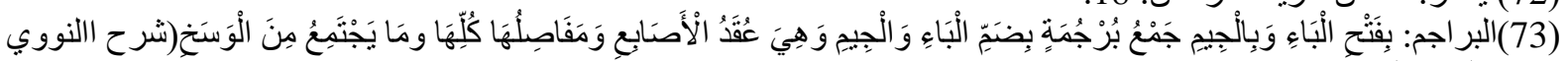
على مسلم:130/ 150).

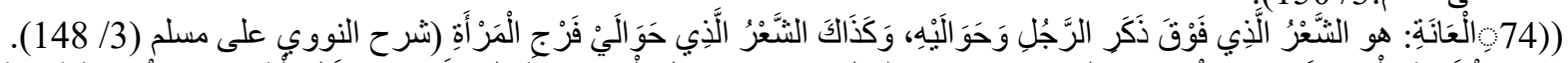

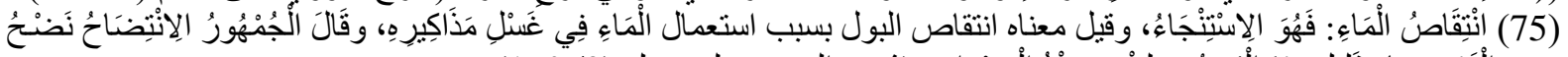

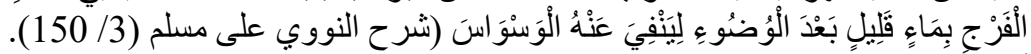

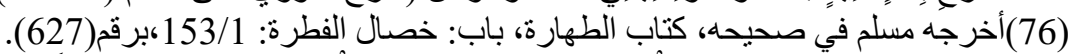

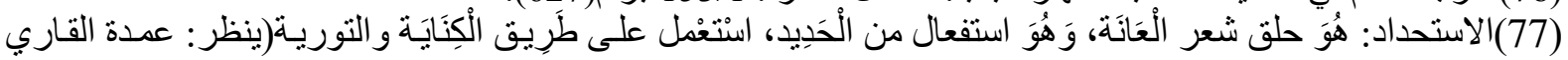

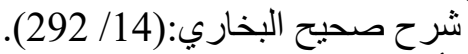

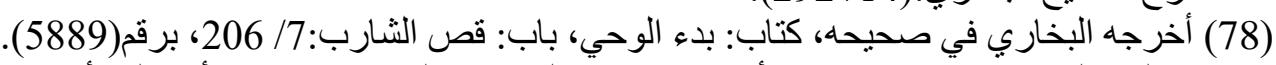

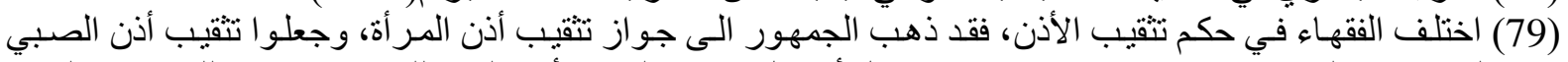

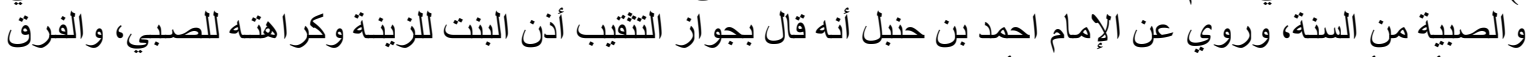

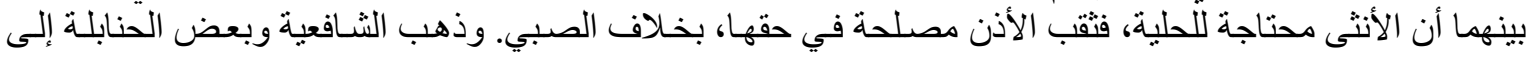

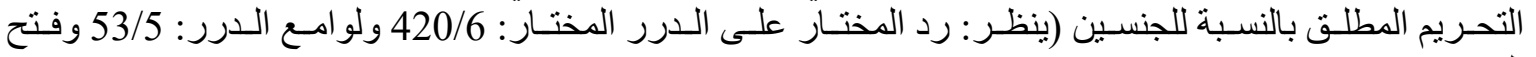


Proceeding of the $2^{\text {nd }}$ Scientific Conference on Women's Health 2-3 September 2020 - Hawler Medical University

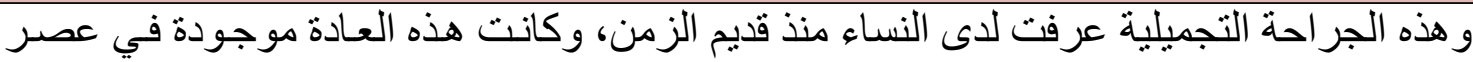

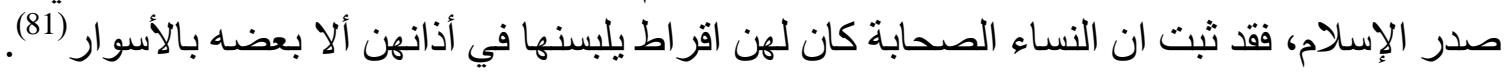

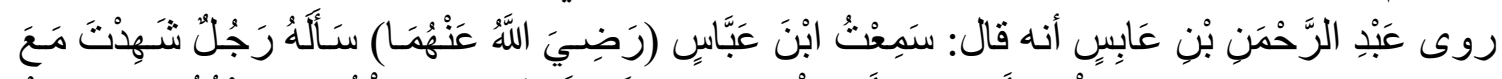

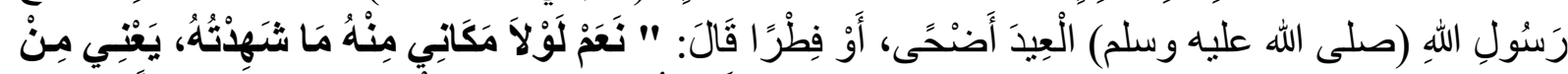

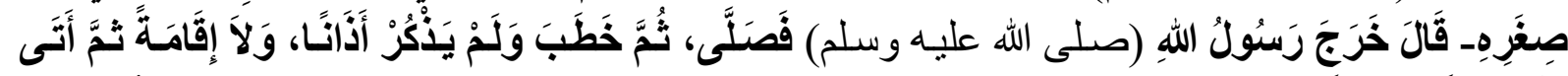

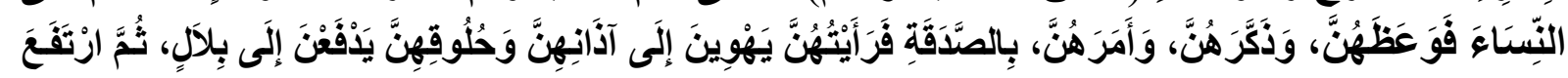

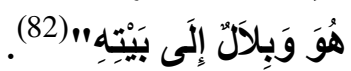

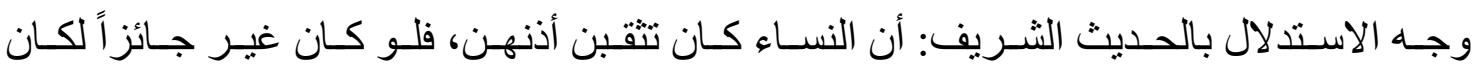
الرسول(صلى الله عليه وسلم) ينهى عنه، و عدم النهي يدل على الجواز النهـ (83).

ثانياً: الجراحة التجميلية غير المشروعة: وتشمل هذا القسم من الجر احة التجميلية الأنواع الآتية: (1) زماعة الشعر وحلقه:

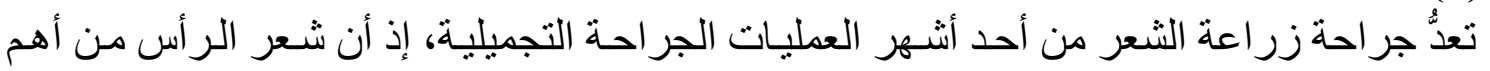

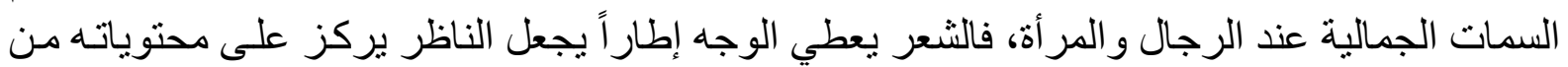
أنف و عينين وفم وفلك، و أنه يجلب الأنظار ويلتفتها إلى التركيز على الهي الجبهة... (84).

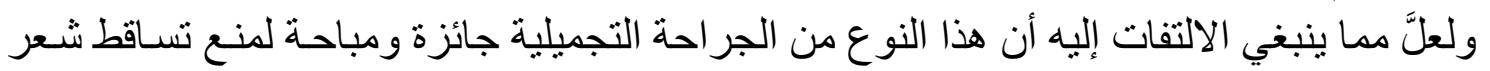

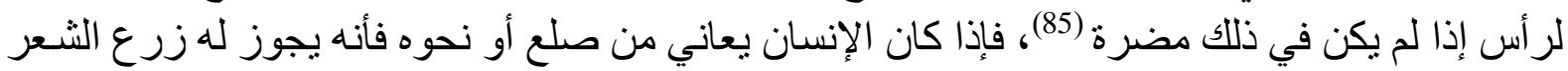
لأنه غير داخل في مسألة الوصول المنهى عنه، بل هو استنبات شعر في جلد الإنسان ذاتـه وليس وفي وصلاً

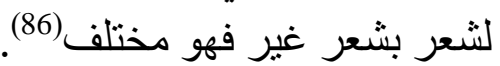

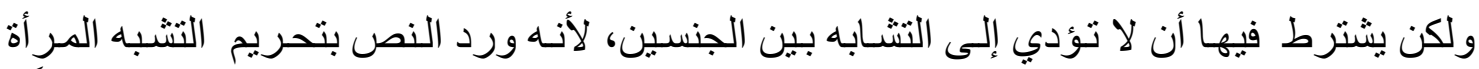

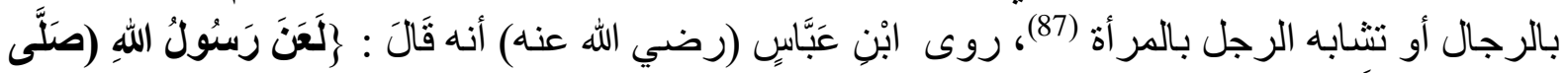

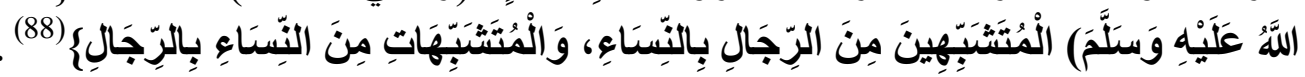

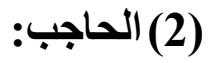

إن جمال الحاجب يؤدى إلى جمال الوجه، أما إذا كان الحاجب أكثر رقيقاً يؤدى إلى تشـوه منظر

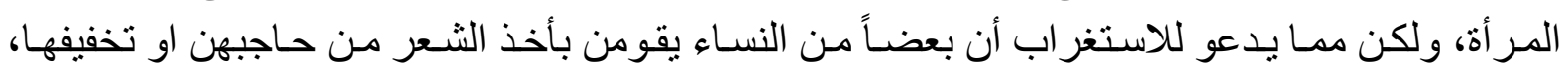

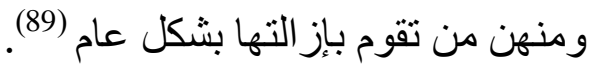

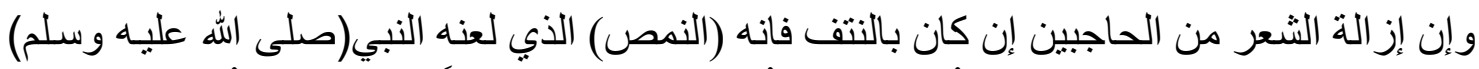

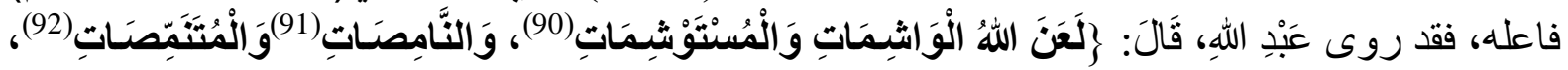

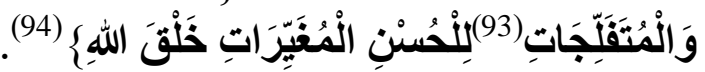

(81) ينظر: أحكام جر احة التجميل: 31.

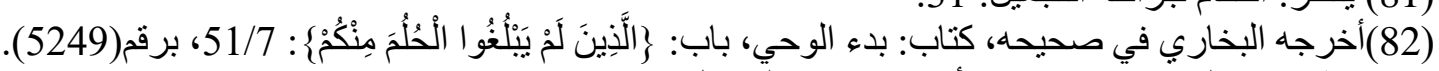

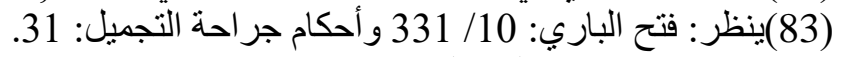

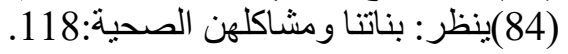

(85) الجامع في فقه العلامة ابن باز :1190)

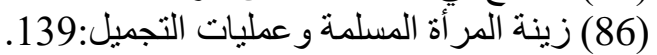

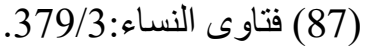

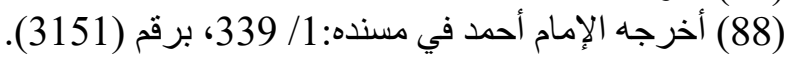
(89)ينظر: فتاوى النساء: 84/3. 
Proceeding of the $2^{\text {nd }}$ Scientific Conference on Women's Health 2-3 September 2020 - Hawler Medical University

فدل الحديث الثريف أن النمص من الكبائر الذنوب، وخص المر أة لأنها هي التي تفعلها غالبا.

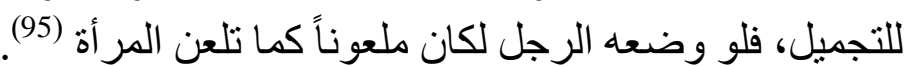

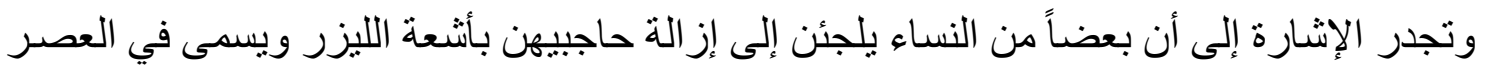

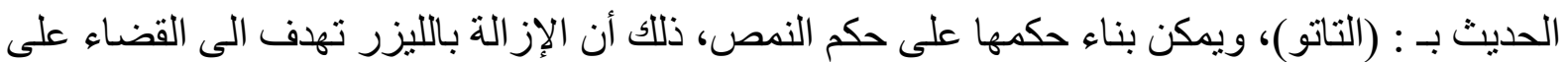

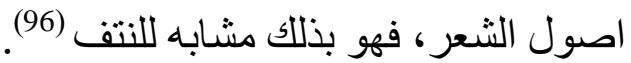
وقد اتفق الفقهاء المعاصرين إلى تحريم الجر احة التجميلية (تاتو)، لأنه يقوم بتغيير خلق الله تعالى، التهائ

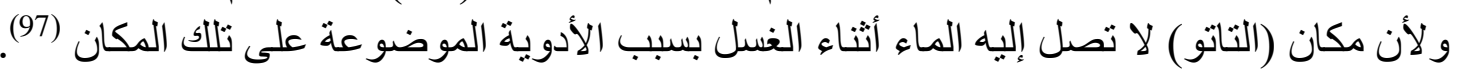

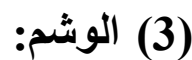

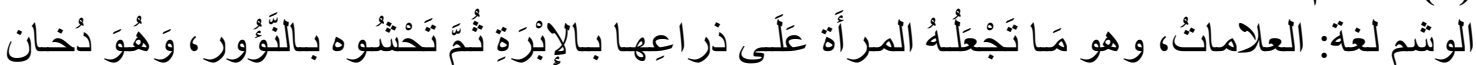

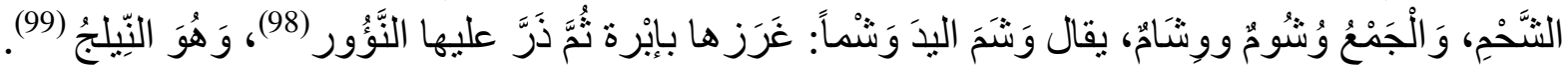

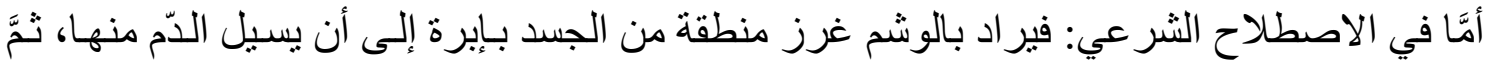

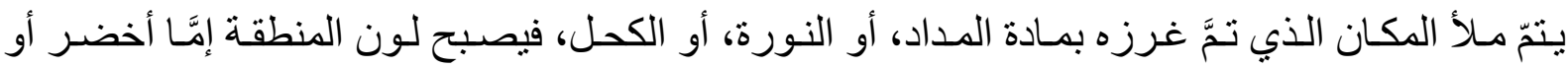

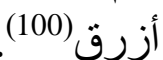

يقول ابن العربي: " فالواشـمة هي التي تجرح البدن نقطاً أو خطوطاً فبإذا جرى اللام حشته كحلاً"(101)

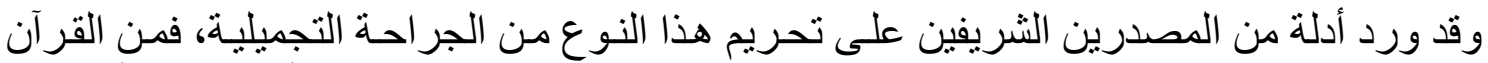

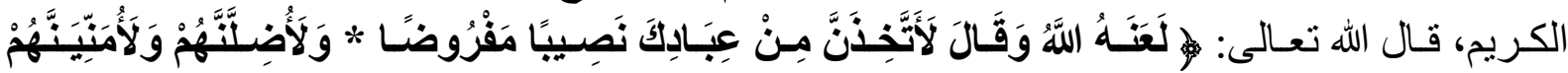

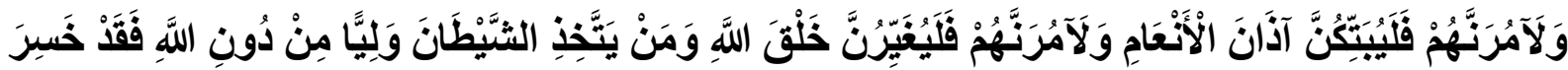

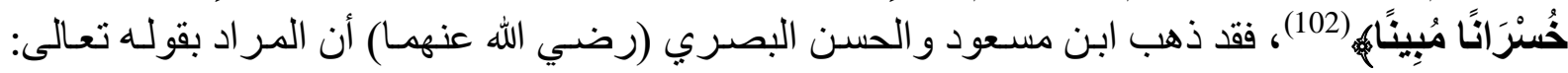

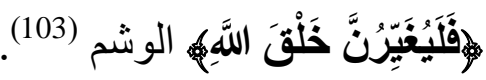

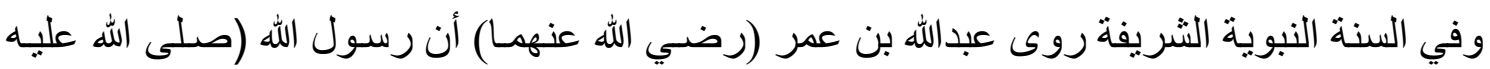

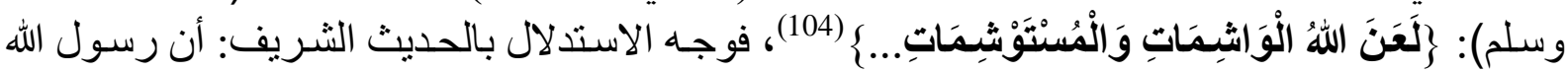

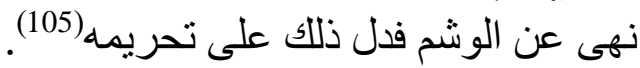

(90) نذكر معني الو اشمات و المستوشمات قريباً.

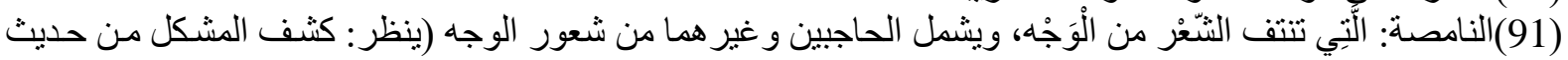
الصحيحين:1/ (273).

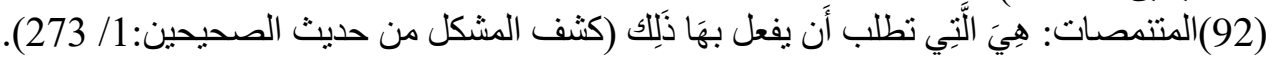

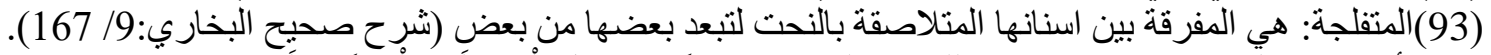

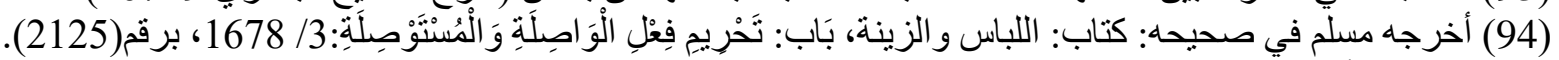
(95) (95) دليل المر أة المسلمة: 729.

(96) الجر احة التجميلية عرض طبي ودر اسلة فقهية مفصلة: 177.

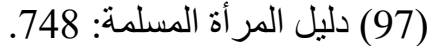

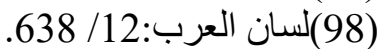

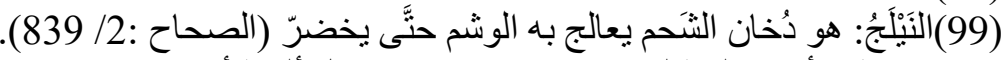
(100) ينظر : أسنى المطالب: 173/1 19301 الإقناع في حل ألفاظ أبي شجاع: 1/ 1/ 151.

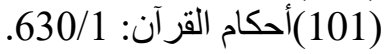
(102) (103) سورة النساء: 119 (103)

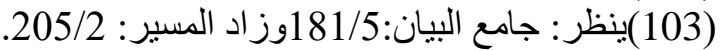

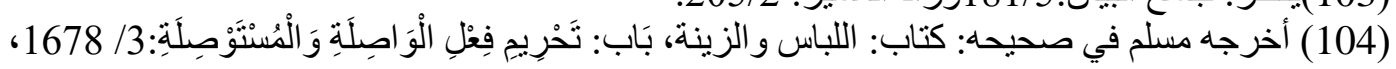


Proceeding of the $2^{\text {nd }}$ Scientific Conference on Women's Health 2-3 September 2020 - Hawler Medical University

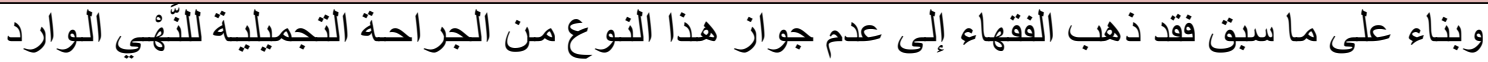

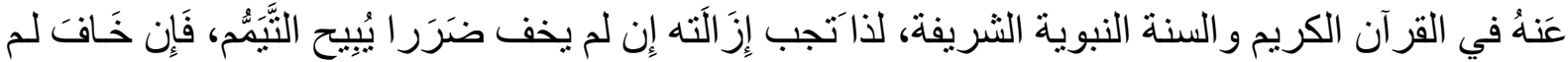

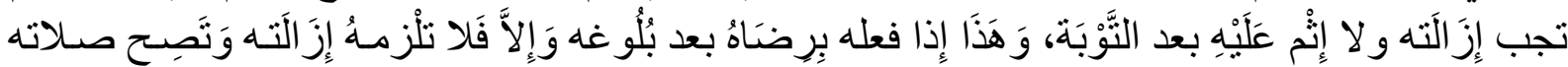

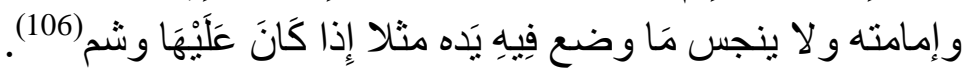

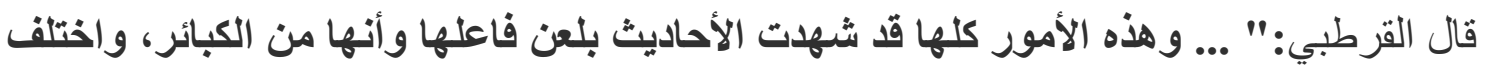

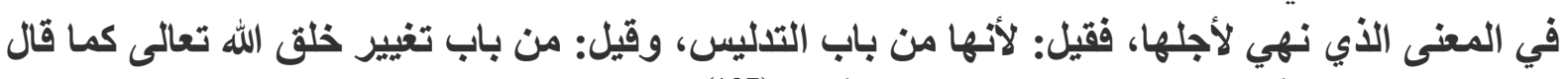

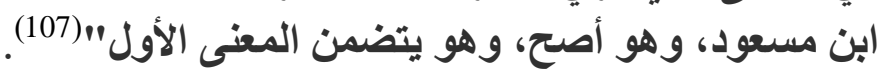

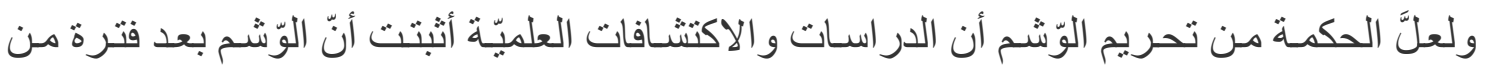

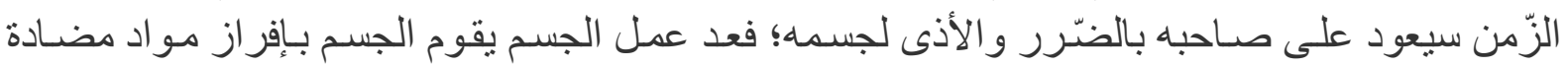

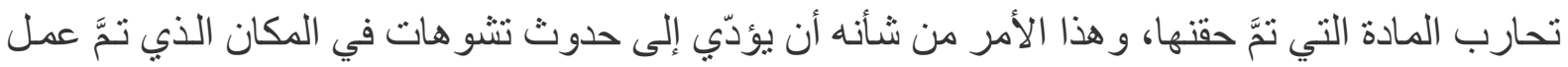

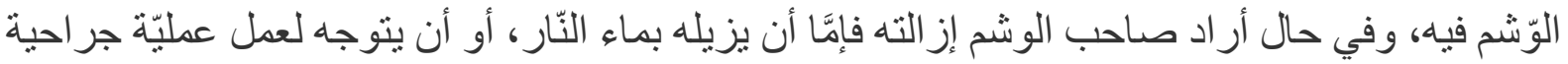

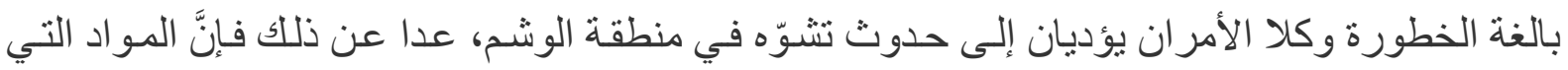

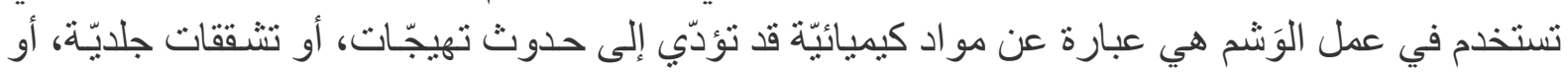
حساسبّة (108)

ولكن على الر غم من عدم جواز هذا النوع من الجر احة التجميلية إلاَّ أن الفقهاء استثنو ا حـالتين من

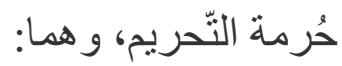
(أ) إذا كان الوَشم للمر أة قاصدةً به التزيّن لزوجها، ويكون عمل الوَشَم بإذنـه، فالوشـم الذي يكون

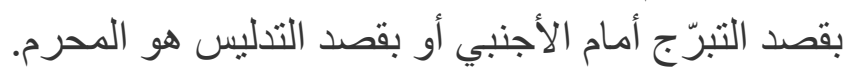

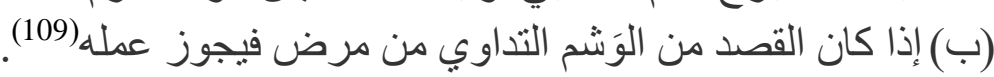

$$
\begin{aligned}
& \text { المبحث الثاني } \\
& \text { موقف الققهاء من الجراحة التجميلية }
\end{aligned}
$$

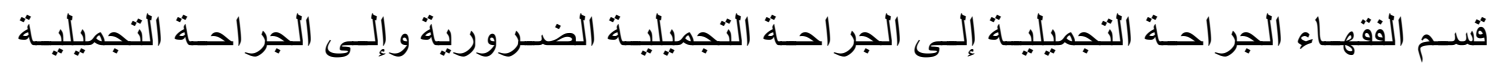
التحسينية، وفيما يأتي نذكر القسمين في مطلبين كالآتي:

\section{المطلب الأول المبلم المبر \\ الجراحة التجميلية الضرورية الأبرل}

يقصد بالجر احة التجميلية الضرورية الجر احة التي بحتاج إليها الإنسان بهدف التداوي و المعالجـة التهاية

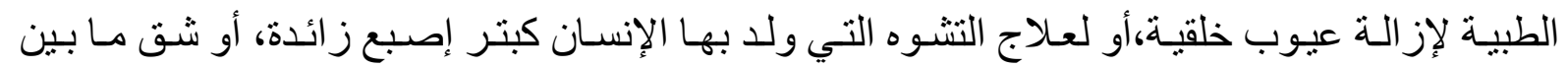

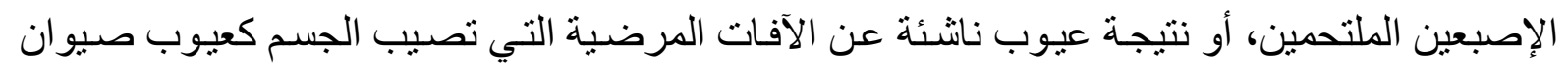


Proceeding of the $2^{\text {nd }}$ Scientific Conference on Women's Health

2-3 September 2020 - Hawler Medical University

الأذن الناثــئة عـن مـرض الزهـرب أو السـل، أو نتيجــة عيـوب مكتسـبة (110) ناثــــة عـن الحـو ادث و الحروق... (111).

ومن الجدير بالذكر أن هذه الأنواع من العمليات جائزة من منظور إسلامي، وسبب جواز ها برجع

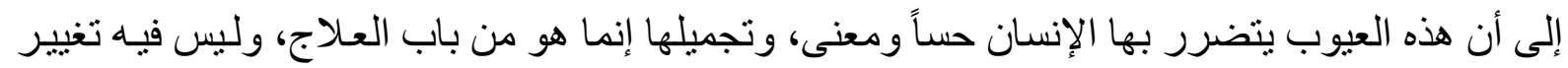

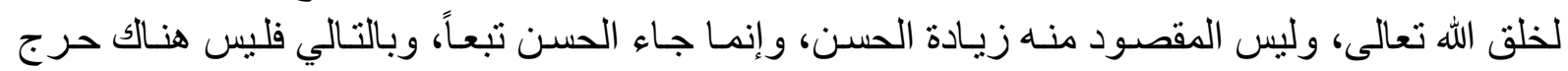

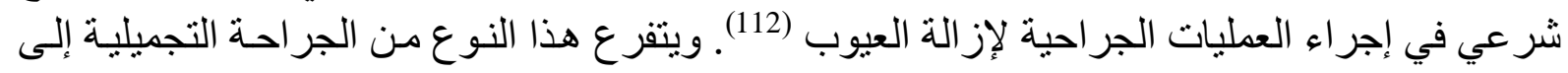

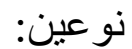

النوع الأول: العيوب الخَلْقِية التي ولا عليها الإنسان:

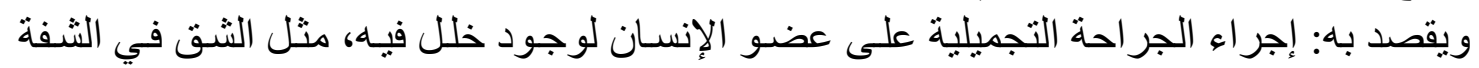

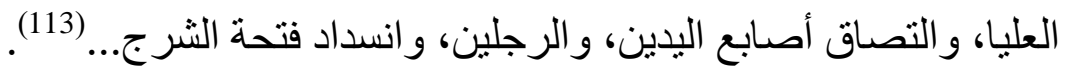

وقد اختلف الفقهاء في حكم هذا النوع من الجراحة التجميلية على قولين نذكر ها كالآتي:

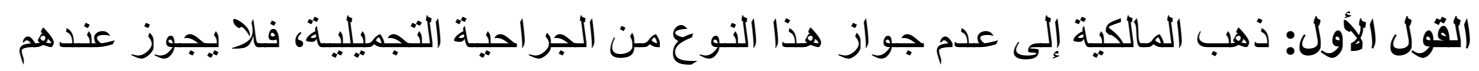

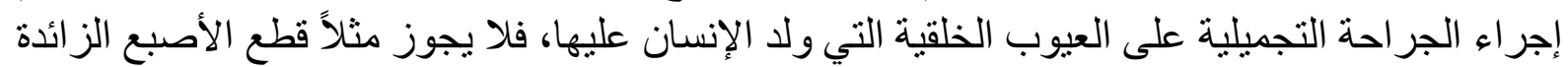

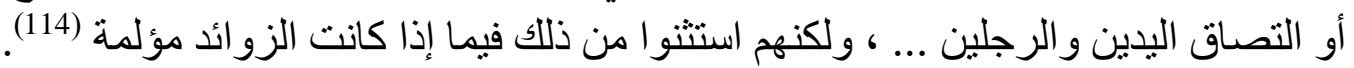

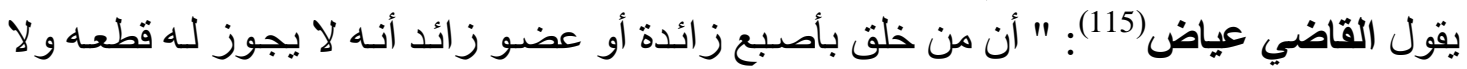

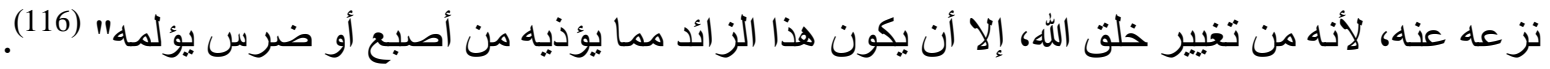

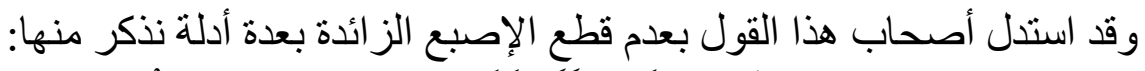

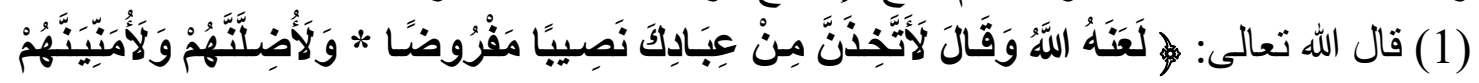

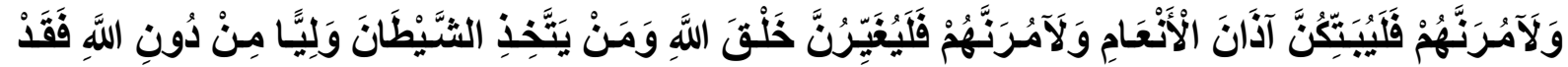

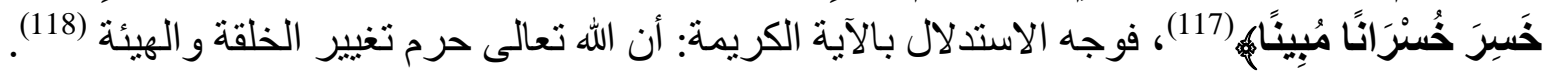

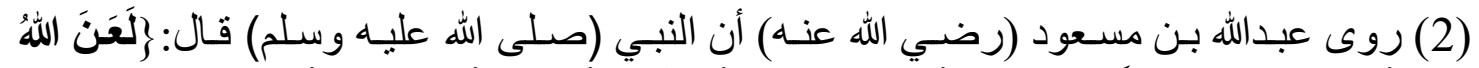

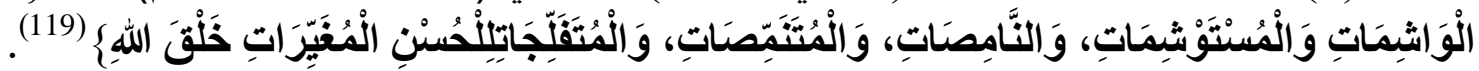

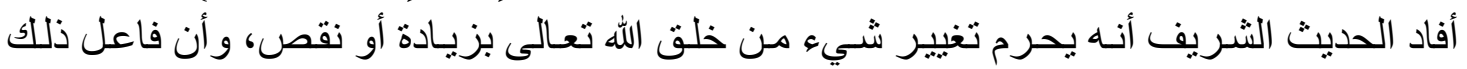
مستحق للعن و الطرد من رحمة الله تعالى (120).

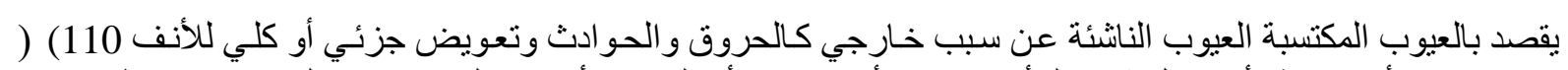

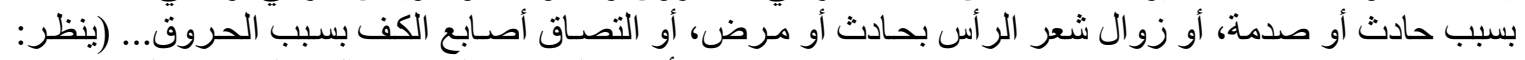

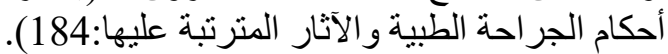

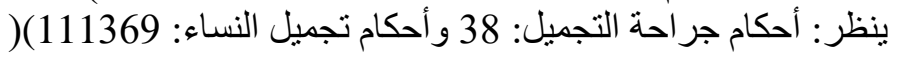

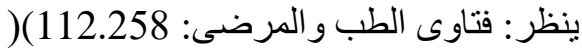

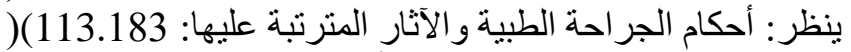

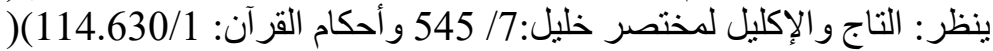

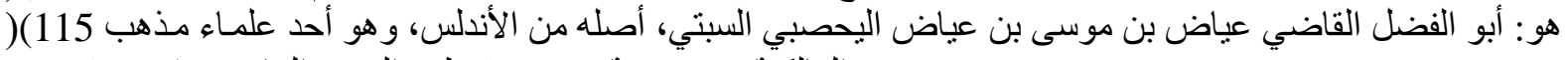

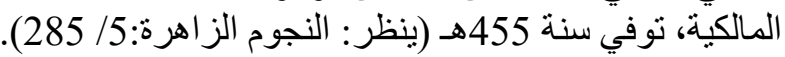

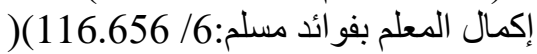

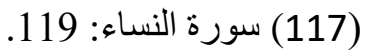

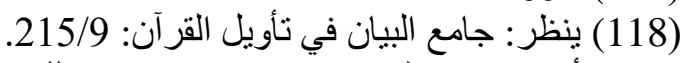

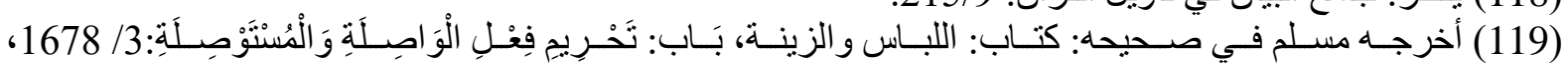

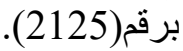

107/14 : 120) بنظر : المنهاج 
Proceeding of the $2^{\text {nd }}$ Scientific Conference on Women's Health 2-3 September 2020 - Hawler Medical University

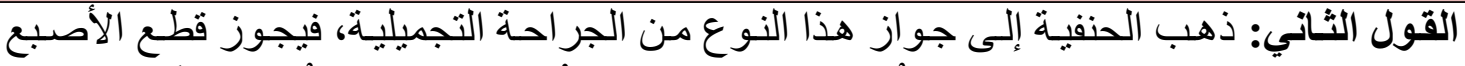

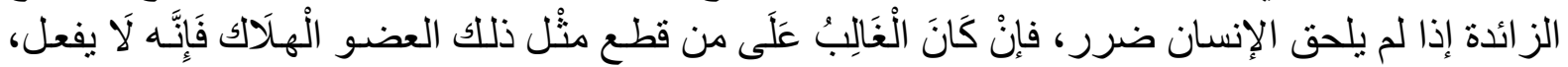

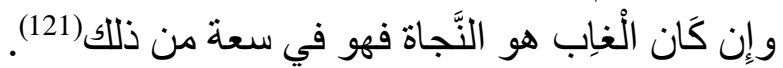

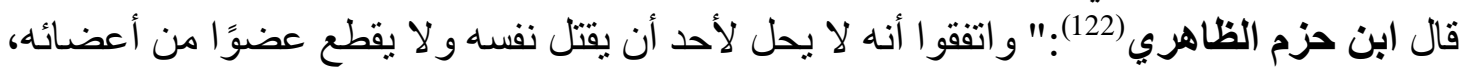

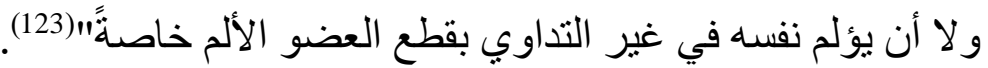

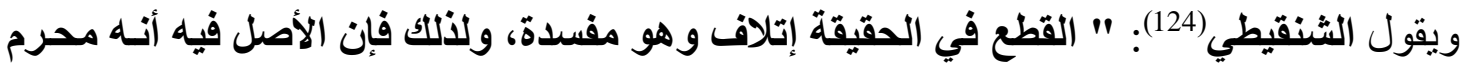

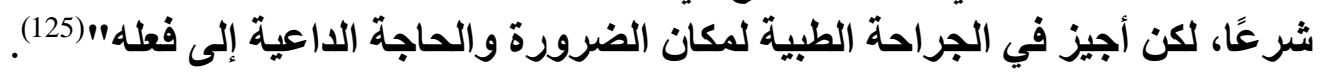

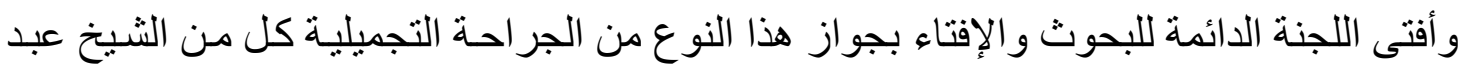

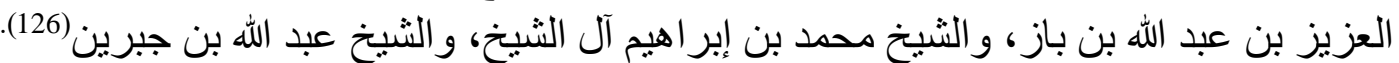

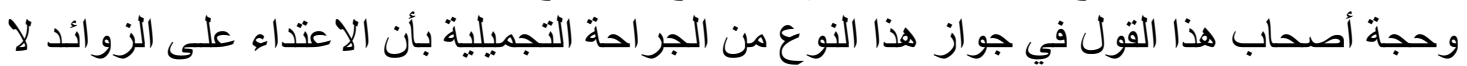

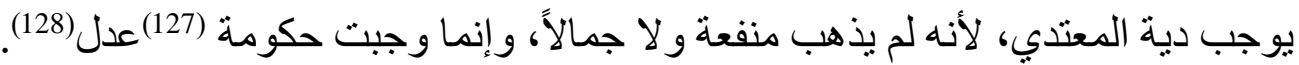

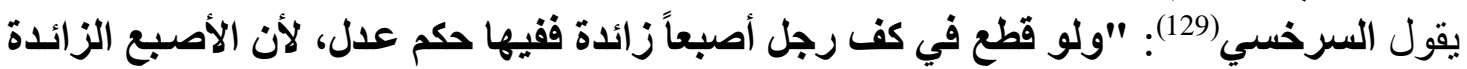

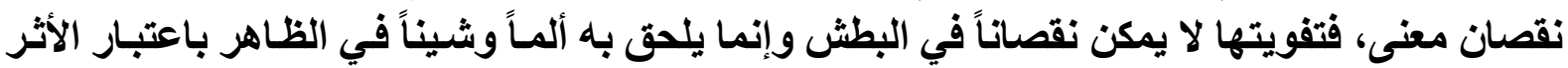

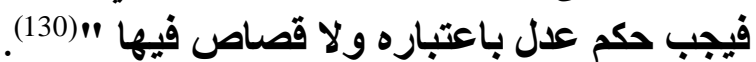

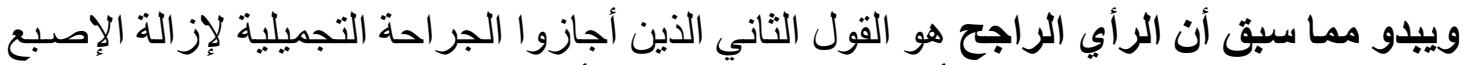

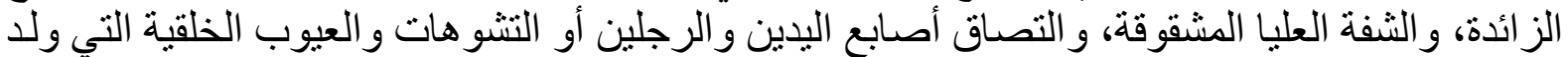

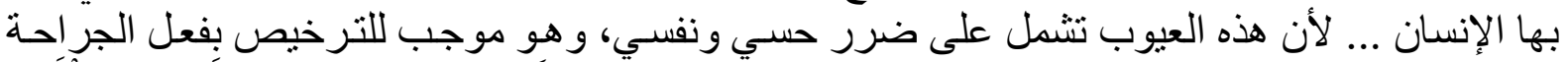

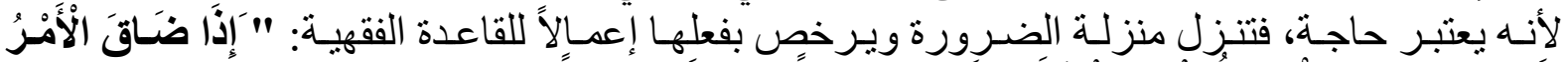

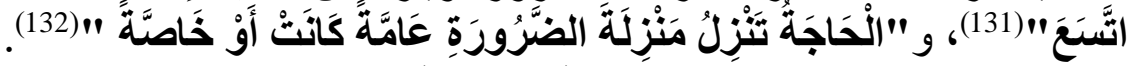
النوع الثاني: العيوب المكتسبة (الطارئة):

(121) ينظر : الفتاوى الهندية:360/5 و عمدة القاري:225/19.

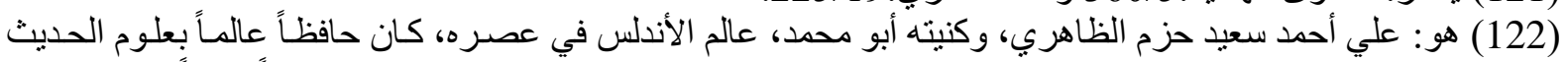

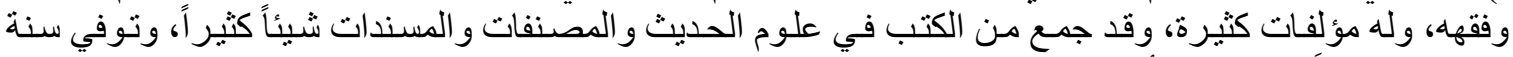

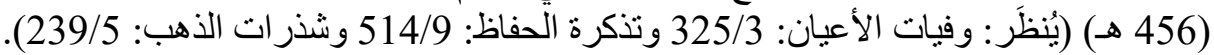

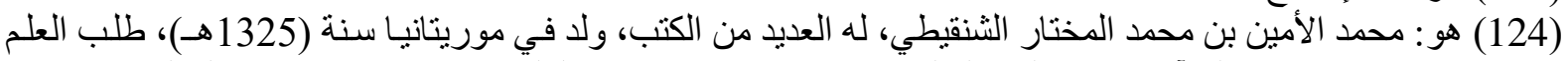

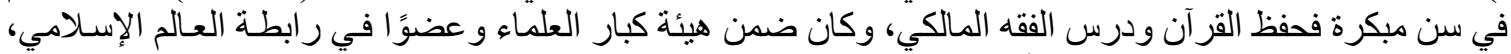

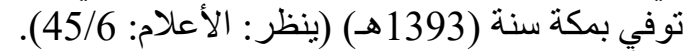
(125) أحكام الجراحة الطبية والآثار المترتبة عليها: 295. (126) ينظر : فتاوى الطب والجرة المرضي:254.

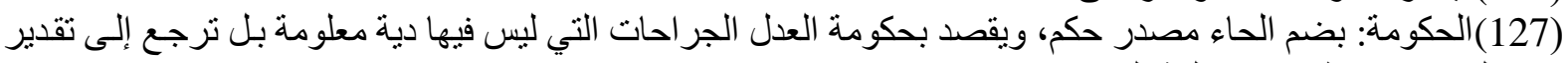
القاضي ( بنظر: معجم لغة الفة الفقهاء:184).

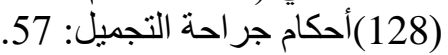

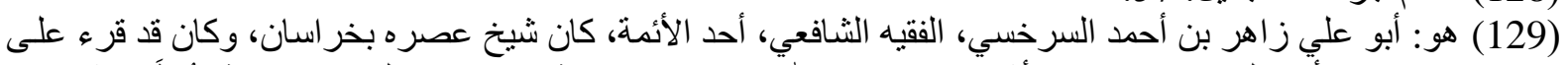

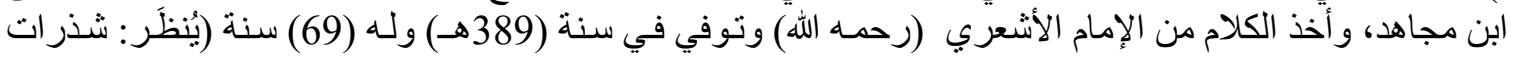


Proceeding of the $2^{\text {nd }}$ Scientific Conference on Women's Health 2-3 September 2020 - Hawler Medical University

يقصد بالعيوب المكتسبة العيوب الناشئُة بسبب خارج الجسم كمـا في العيوب و التشوهات الناثـئة

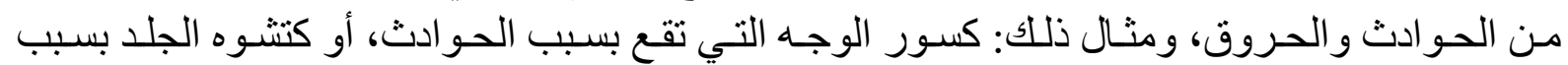
الحروق، أو كتشوه الجلد بسبب الآلات القاطعة.... (133).

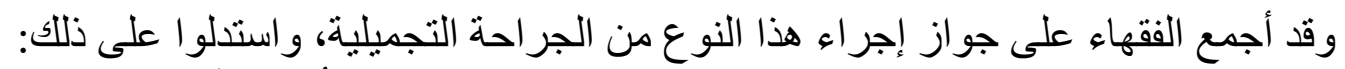

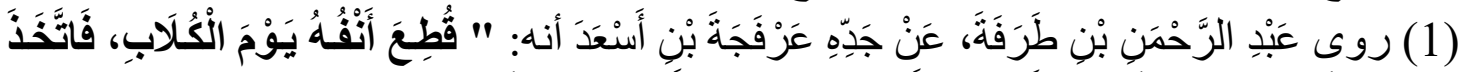

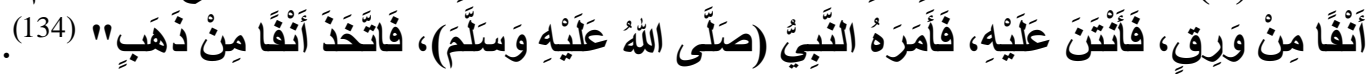

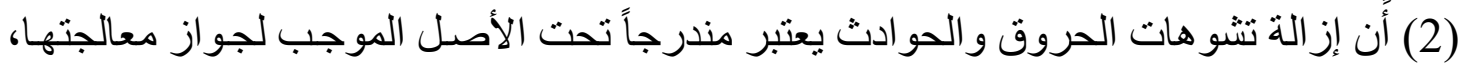

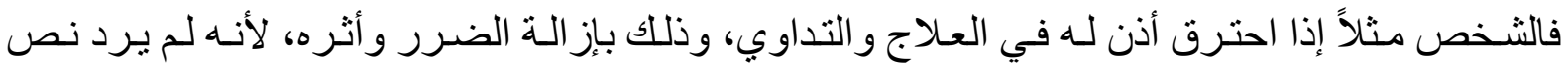

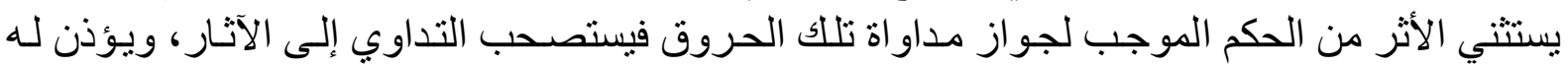
باز التها. (3) أن هذا النوع لا يشتمل على تغيير الخلقة قصداً، لأن الأصل فيه أنه يقصد منـه إزالة الضـرر و التجميل و الحسن جاء تبعاً (135).

\section{المطاب الثاني \\ الجراحة التجميلية التحسينية صور ها وحكمها \\ أولاً: صور الجراحة التجميلية التحسينية:}

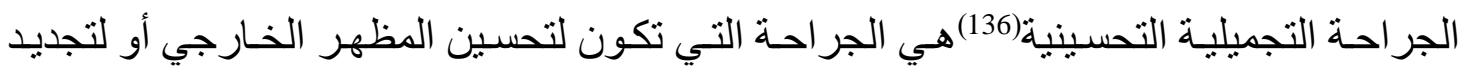
الثباب في نظر فاعلها، مثل تجميل الأنف بتصغيره، أو تجميل الثديين بتصغير هما أو تكبير هما، ومثنل

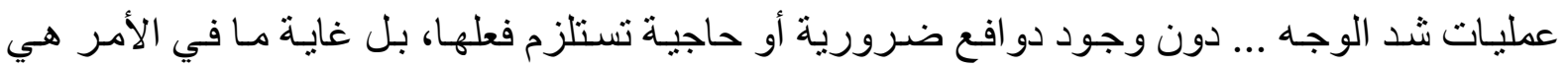

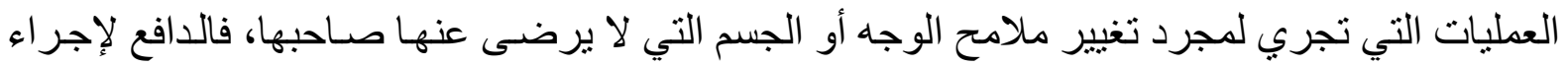
مثل هذه العمليات هو محض تغيير الشكلئ(137). و هنالك صور عدة للجر احة التجميلية التحسينية، ويمكن تقسيم صور ها إلى نوعين كالآتي:

\section{النوع الأول: عمليات الشكل، وتشمل:}

(1) تجميل الأنف، حيث يتم إعادة تشكيل الأنف بزيادة إنقاص الحجم أو إز الة الانعكاف، أو تغير

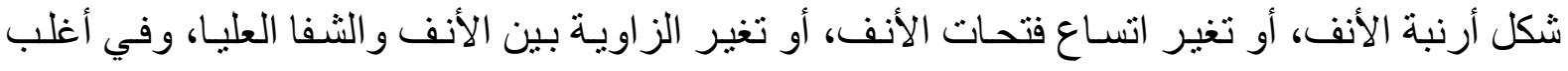
الأحو ال تجري هذه العملية من أجل تصغير الأنف النف (138).

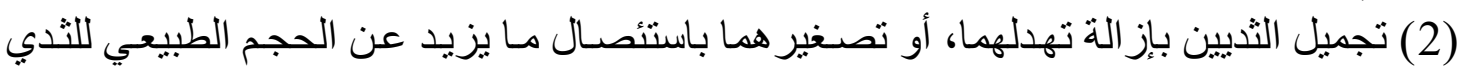

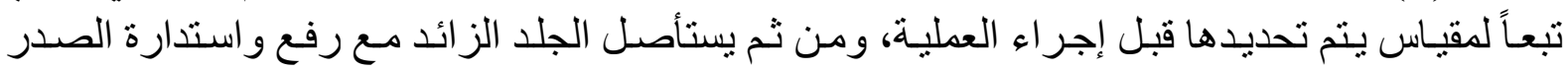

(133) ينظر : أحكام الجر احة الطبية والآثار المترتبة عليها: 185 أحسام أحكام تجميل النساء:370.

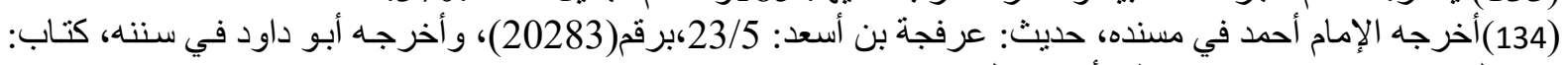

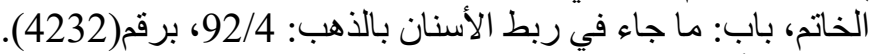

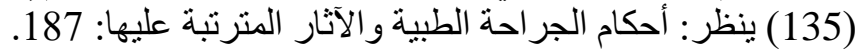

(136)التحسين: الزيادة المنولدة من الأصل، أو الانتقاص من الأصل الصن (معجم لغة الفقهاء: 123).

(137)ينظر : أحكام تجميل النساء: 1369 (136)

(138) ينظر : أحكام الجراحة الطبية والآثار المترنبة عليها:192. 
Proceeding of the $2^{\text {nd }}$ Scientific Conference on Women's Health

2-3 September 2020 - Hawler Medical University

للحصول على الثكل الأمثل، أو تكبير هما بوضع جهاز تعويضي تحت الجلد أو العضلات لإبراز الثدي،

أو باستخدام المعدات الصناعية (139).

(3) تجميل الأذن بردها للور اء إن كانت متقدمة، أو لتصغير حجمها.

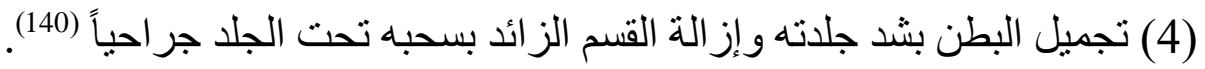

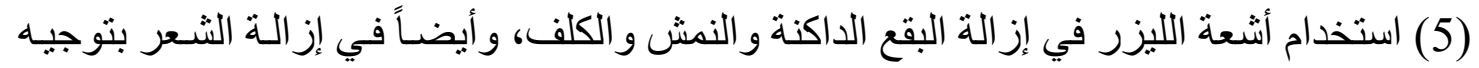

الأشعة إلى بصيلات الثعر أو الخلايا الصبغية بها، وفي الصنفرة (التقشير)، بتوجيه الأشعة إلى بروتين

معين موجود في الخلايا السطحية للجلد (141).

النوع الثاني: عمليات التشبيب:

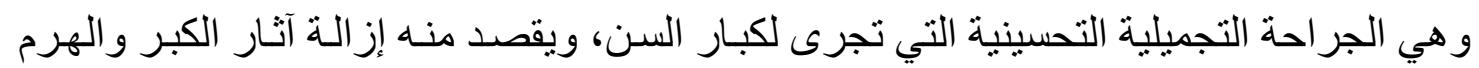

و الثيخوخة (142)، فيبدو الهرم شاباً فتياً، وفي عنفوان الثباب في شكله وصورته (143)، وهي أنواع:

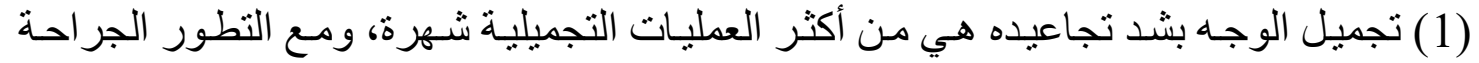

التجميلية أصبحت عملية شد الوجه و إز الة التجاعيد وسيلة للحصول على وجه أكثر نضارة و أكثر جاذبيـه

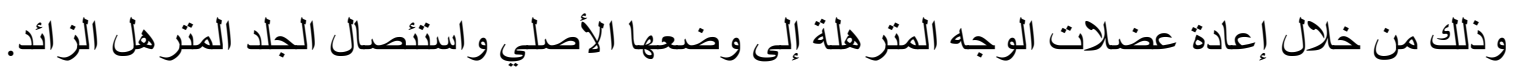

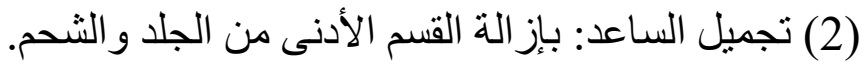

(3) تجميل اليدين: ويسمى في عرف الأطباء بتجديد شباب اليدين، وذللك بشد التجاعيد.

(4) تجميل الحواجب: وذلك بسحب المادة الموجبة لانتفاخها، نظر اً لكبر السن و التقدم بالعمر.

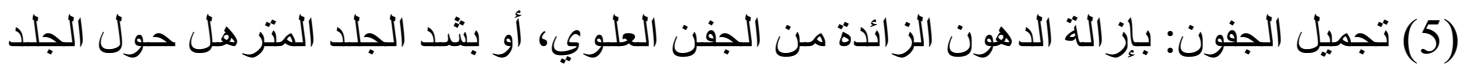

الذي ينتج عن التقدم بالعمر.

(6) تجميل الجسم: بشفط الدهون، حيث يتم إز التة الدهون الز ائدة بالجسم الثابتة العميقة التي لا

تتغير بمعدلات الغذاء أو الرياضة(144).

ثاتياً: حكم الجراحة التجميلية التحسينية:

اختلف العلماء في حكم هذا النوع من العمليات الجر احية على ثلاثة أقو ال نذكر ها كالآتي:

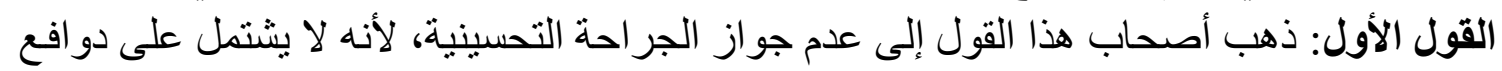

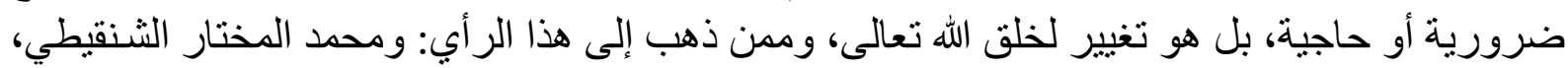
و ابن عثيمين، ومحمد عثمان شبير (145). وقد استدل أصحاب هذا القول بعدم جواز الجر احة التحسينية بما يأتي:

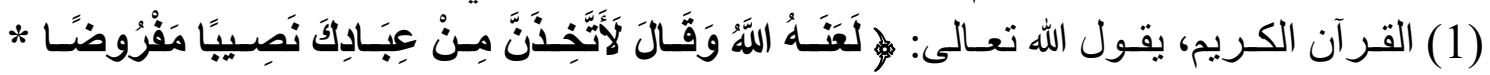

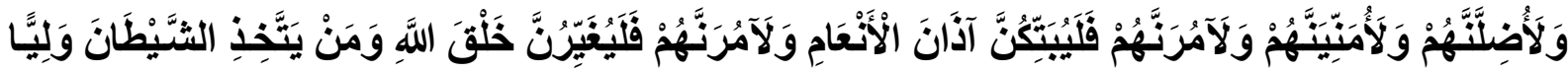

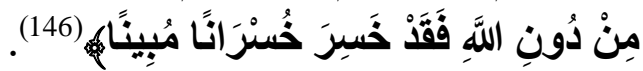

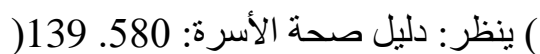

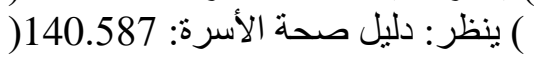

) ينظر: أحكام الجر احة الطبية والآثار المترتبة عليها: 192. 141ة 142.

) ينظر : المصدر نفسه: 142.192( 
Proceeding of the $2^{\text {nd }}$ Scientific Conference on Women's Health 2-3 September 2020 - Hawler Medical University

وجه الاستدلال: أن هذه الآية الكريمة واردة في سياق الذم، وبيـان المحرمـات التي يسول الثبطان

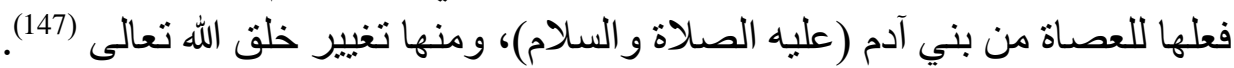

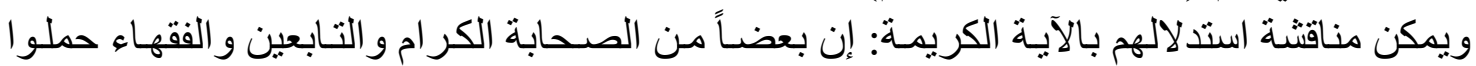

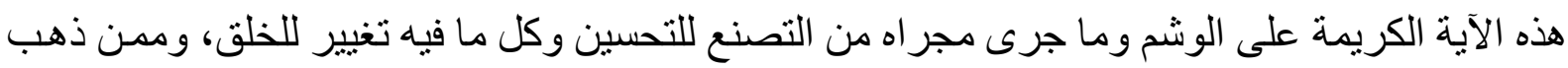

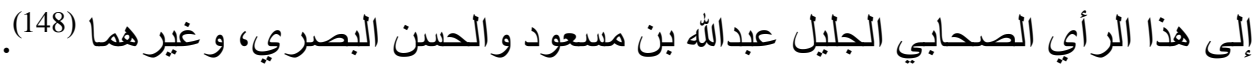

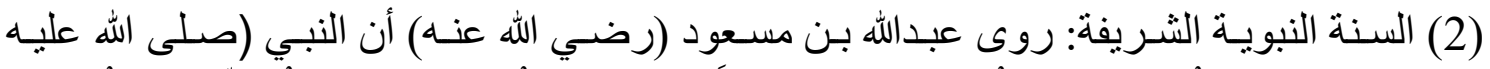

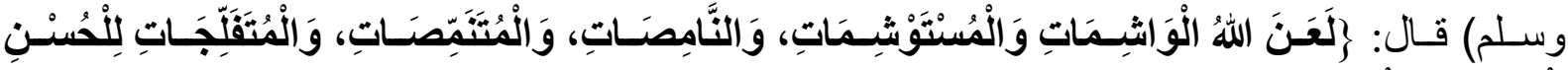

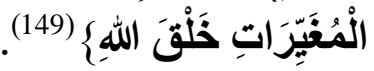
يقول النووي: "وفيه إثـارة إلى أن الحر ام هو المفعول لطلب الحسن، أما لو احتاجت إلبه لفلاج أو عيب في السن ونحوه فلا بأس" (150) (3)(القياس: لا تجوز جر احة التجميل التحسينية كما لا يجوز الوشم، و الوشر ، و النمص بجامع تغيير الخلقة في كلّ، طلباً للحسن و الجمال(151). (4) الأدلة العقلية: إن هذه الجر احة لا يتم فعلها إلا بار تكاب بعض الته المحظور ات ومنها:

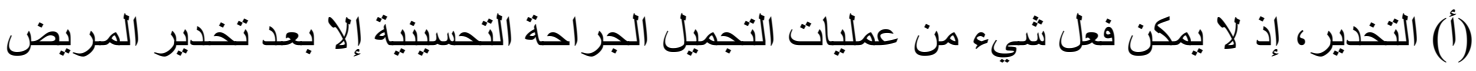

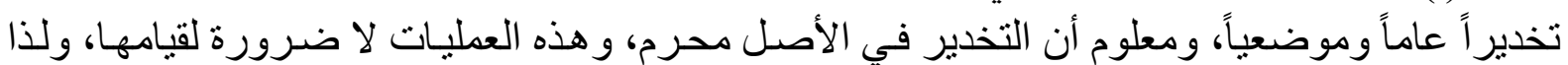

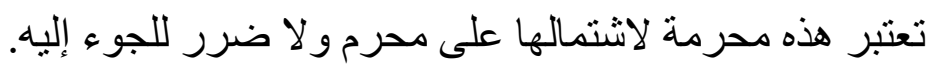
(ب) فيها كثف للعور ات بدون حاجة لاتئ.

(ج)التجربة والو اقع التي شهدتها هذه العمليات بأنها لا تخلو من الأضر ار و المضاعفات(152).

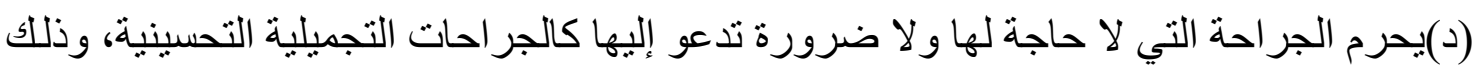

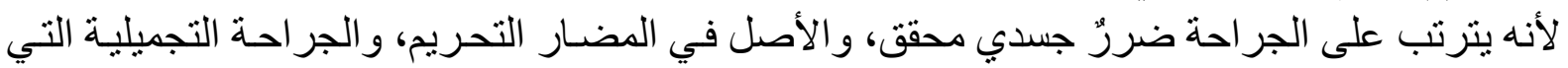

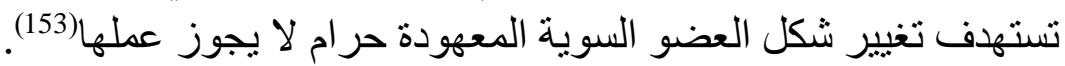

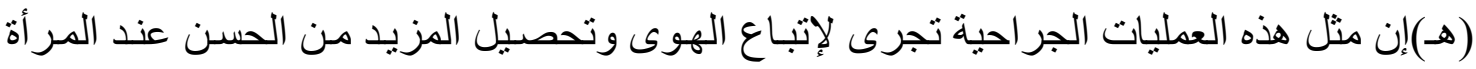
غالباً، حيث تتطلع إلى حسن وجمال مبالغ فيه بتغيير خلق الله تعالى فتارة، تغير شكل أنفها إتباعاً للموضة ألته

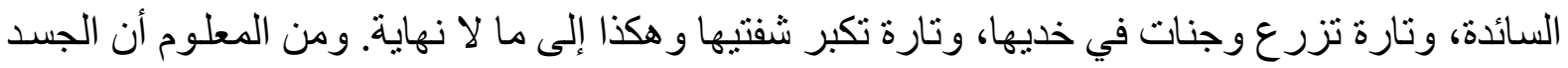

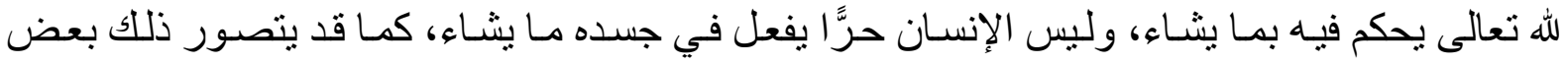

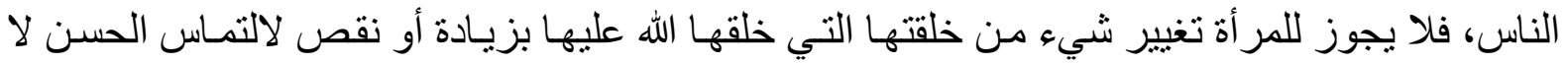
للزوج و لا لغيره (154). القول الثاني: ذهب بعض العلماء المعاصرين (155) إلى جواز الجر احة التجميلية التحسينية مطلقاً، وقد استدلو ا على جواز هذا النوع من الجر احة التجميلية بعدة أدلة نذكر منها:

(147)(أحكام الجر احة الطبية والآثار المترتبة عليها: 192. (148) ينظر : الجامع لأحكام القرآن: 393/5 والبحر البحار المحيط:369/3.

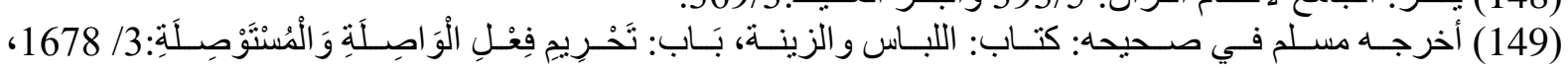

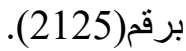

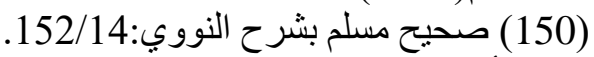

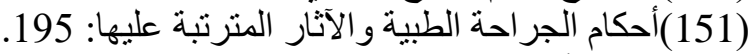
(أحكام الجر احة الطبية والآثار المترنبة عليها: 153.196(

(152)ينظر : أحكام الجر احة الطبية والآثار المترتبة عليها: 195. 
Proceeding of the $2^{\text {nd }}$ Scientific Conference on Women's Health

2-3 September 2020 - Hawler Medical University

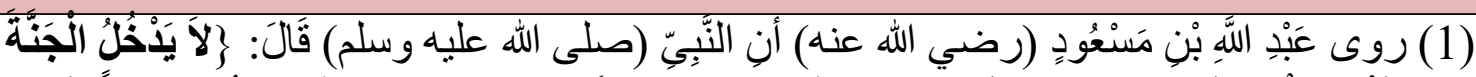

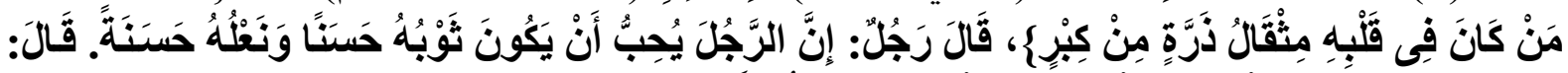

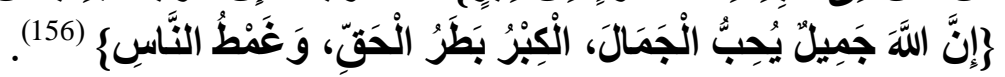

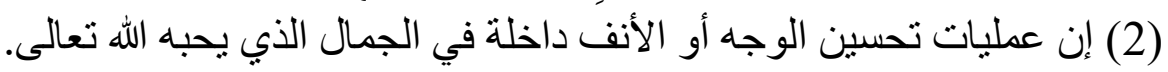

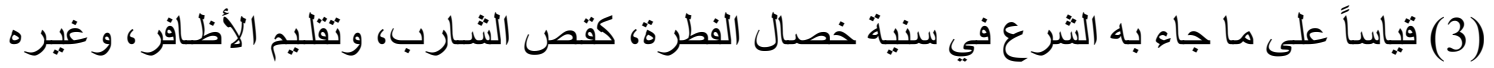

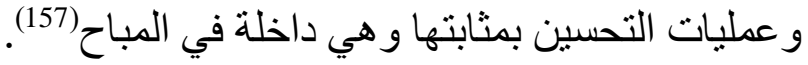

القول الثالث: ذهب أصحاب هذا القول إلى جواز الجراحة التجميلية التحسينية إذا كانت محققة

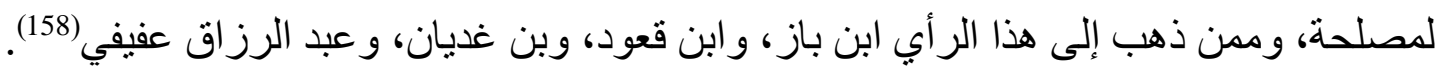

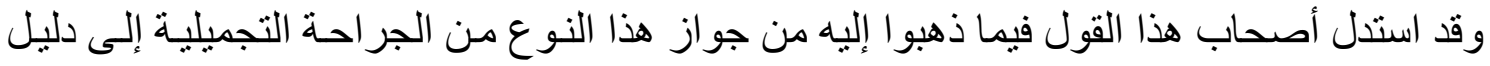

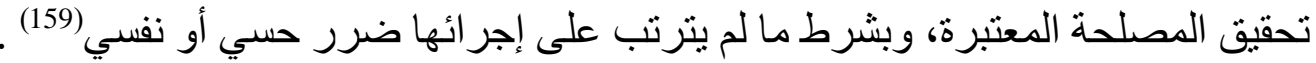

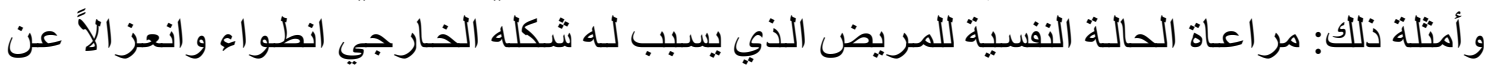
المجتمع فيرخص له إجر اء هذه اعناء العملية (160).

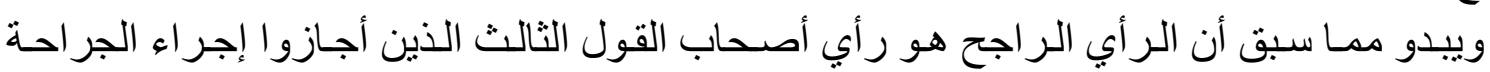

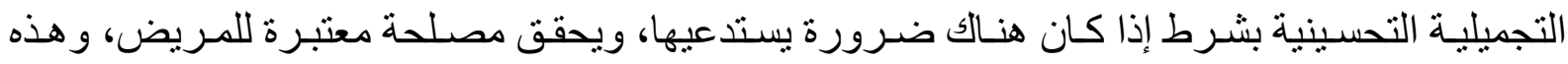

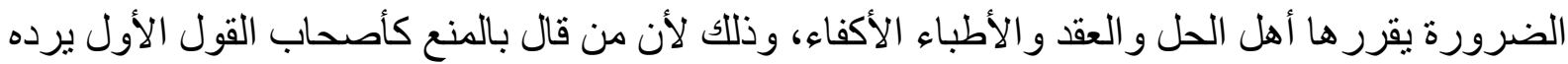

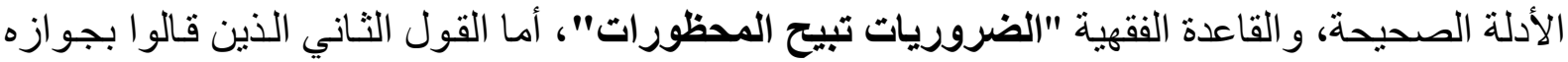

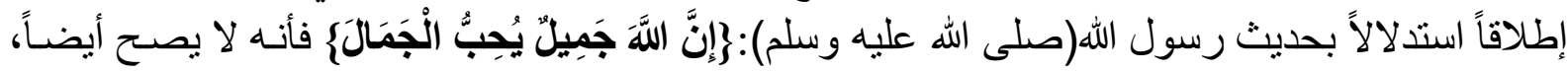

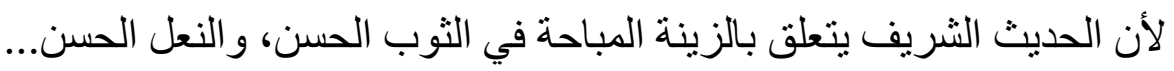

\section{الخاتمة}

وفي ختام البحث توصلت إلى جملة نتائج أبرز ها كما يأتي:

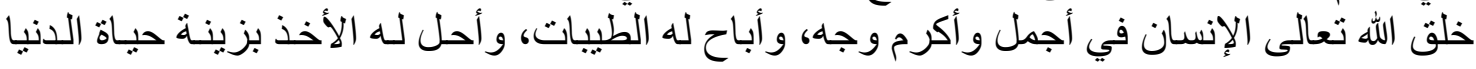

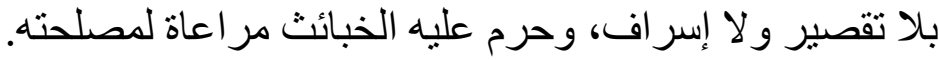

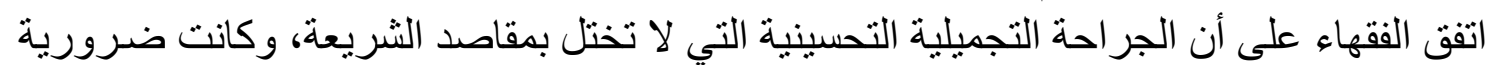

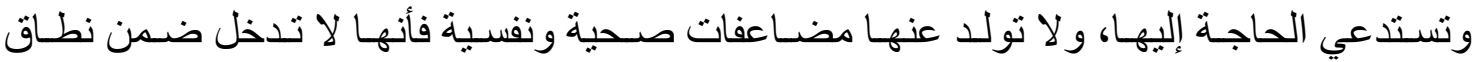

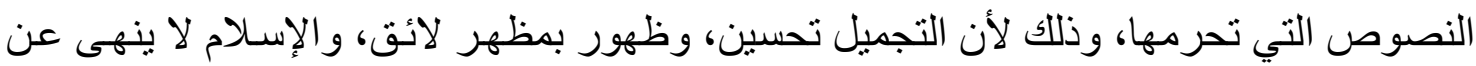
ذللك بل يؤدها.

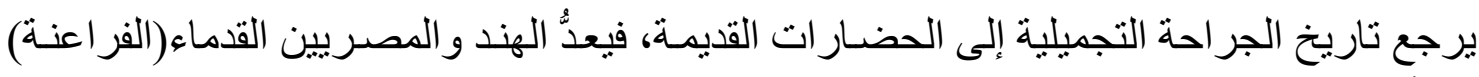

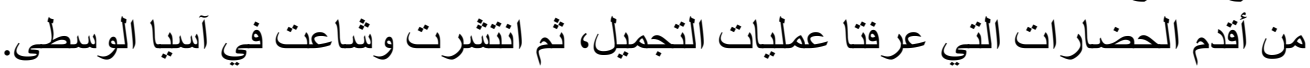


Proceeding of the $2^{\text {nd }}$ Scientific Conference on Women's Health

2-3 September 2020 - Hawler Medical University

ساهم المسلمون في عصر الإسـلامي وبدور فعـال في النهضـة العلميـة التي شهـتها العـالم أنذاك،

وكانت على الجر احة التجميلية إقبال واسع في أوسـاط الاجتماعيـة بعد أن رخص النص النبي (صلى الله

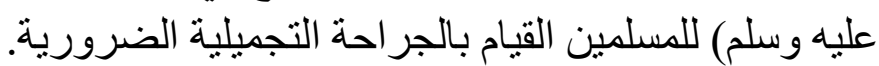

برز كثير من الأطباء الجر احين في المجتمع الإسلامي، الذين كان لهم دور ريادي في تطور مجال

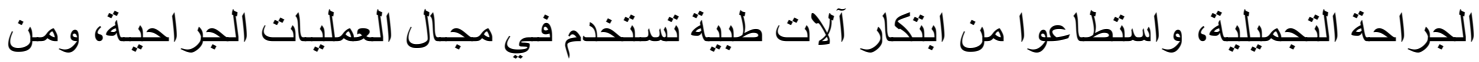

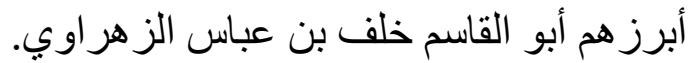

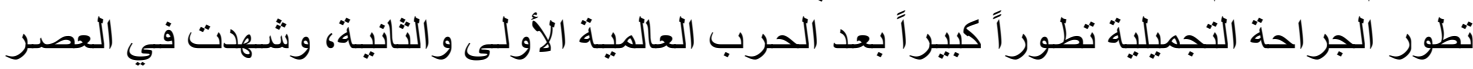

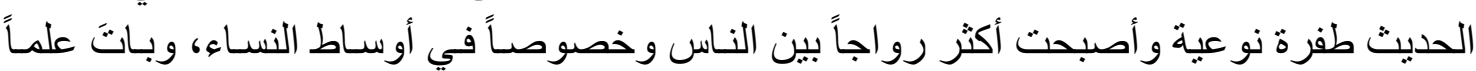

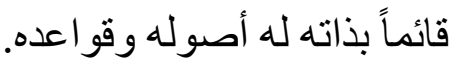

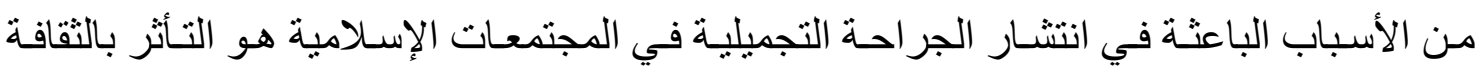

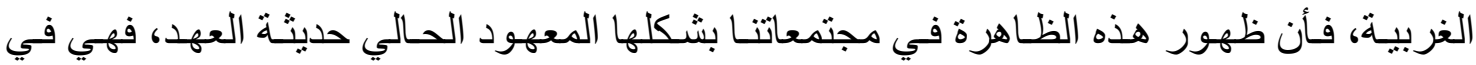
جو هر ها تقليد للتقافة الغربية. المر اد بالجر احة التجميلية في الاصطلاح الثر عي كل عمليات جر احية من شأنها تحسين المظهر

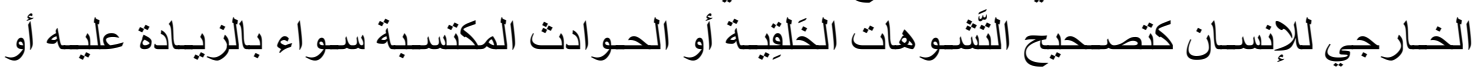

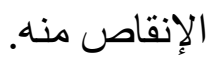

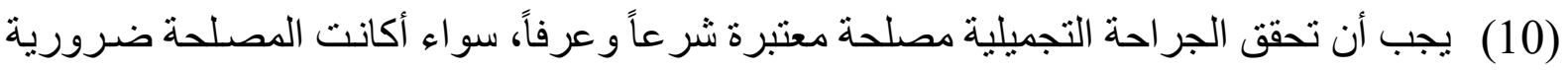

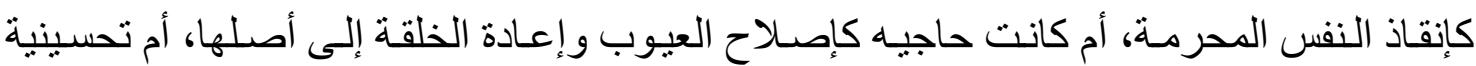
كتجميل آثار الجروح.

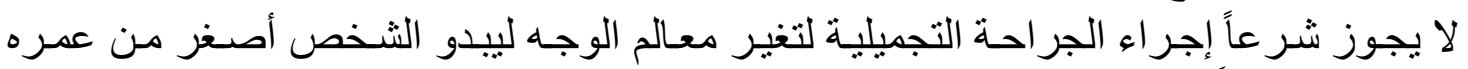

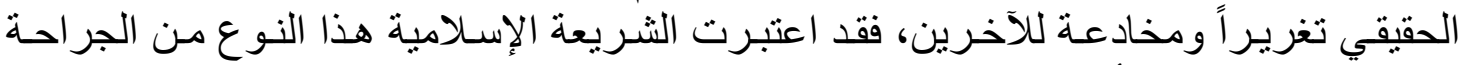

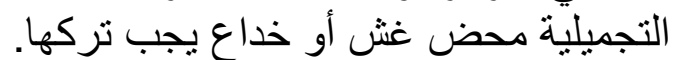

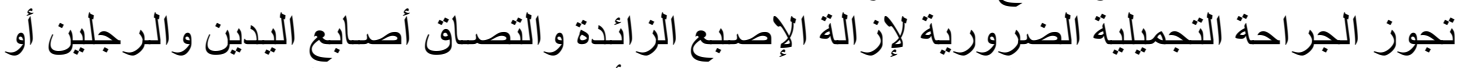

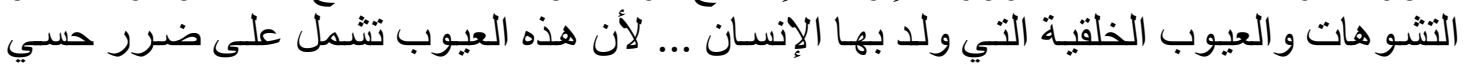

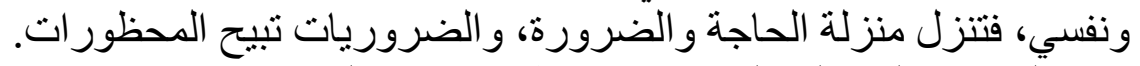

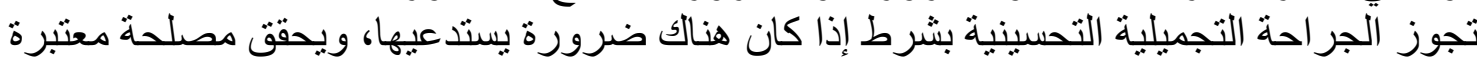
للمريض، و هذه الضرورة يقرر ها أهل الحل و العقد و الأطباء الأكفاء.

\section{التوصيات}

وأخير أ أقتر ح بعض التوصيات على أصحاب الثنأن و العلم رجاء مر اعاتها والأخذ بها:

(1) تفعيل دور الأئمة والخطباء في المساجد لتو عية الناس و إرشادهم إلى بيان المسائل الثر عية المتعلقة

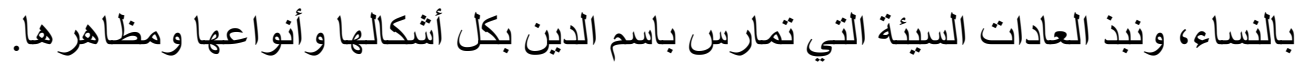

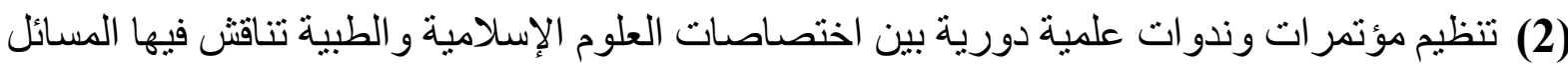

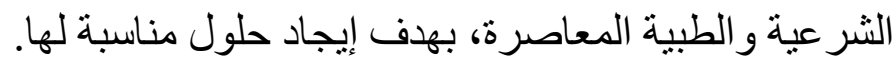

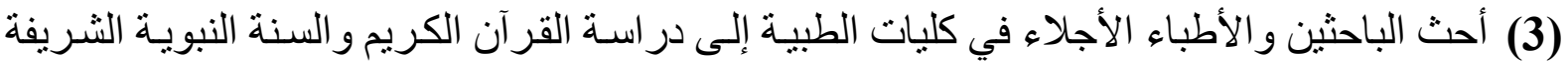
لبيان أوجه العلمية والطبية فيهما، وذللك بالتنسيق والتعاون مع الباهية الباحثين في كليات العلوم الإسلامية. 


\section{قائمة المصادر والمراجع}

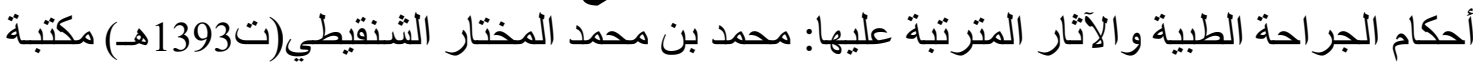

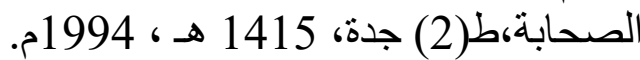

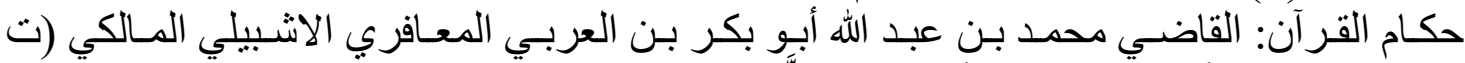

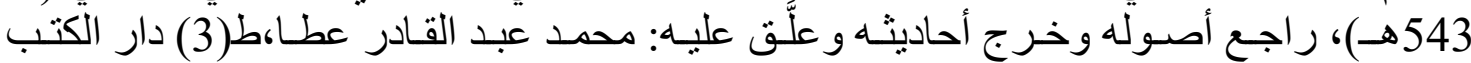

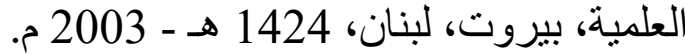

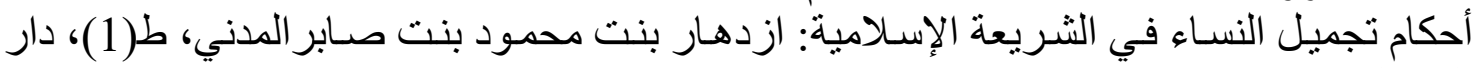

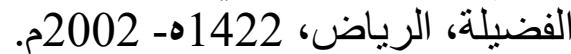
أحكام جر احة التجميل في الفقه الإسلامي: محمد عثمان شبير، كلية الثريعة و الدر اسات الإسلامية، كويت (على موقع المكتبة الثناملة). إرشاد الساري لثر حصح صحيح البخاري: أحمد بن محمد بن أبى بكر بن عبد الملاك القسطلاني القتيبي

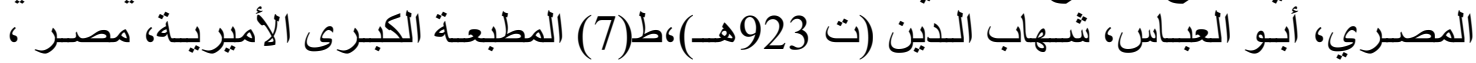
هـ 1323

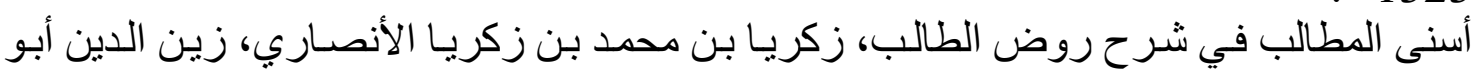

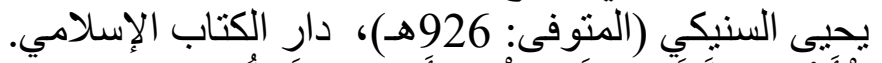

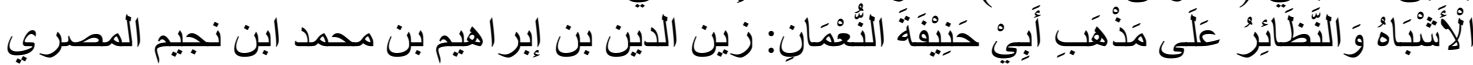

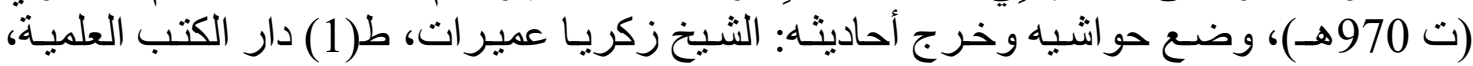

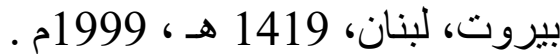
الأشباه و النظائر : تاج الدين عبد الوهـاب بن تقي الدين السبكي (ت 771هـ)، ط(1) دار الكتب

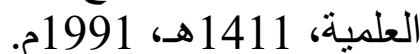
الأشباه والنظائر: عبد الرحمن بن أبي بكر ، جلال الدين السيوطي (ت 911هـ)،ط(1) دار الكتب

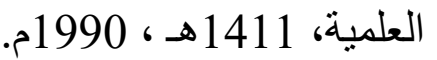

1الإصابة في تمييز الصحابة: أحمد بن علي بن حجر أبو الفضل العسقلاني الثنافعي(ت 852 هـ هـ)

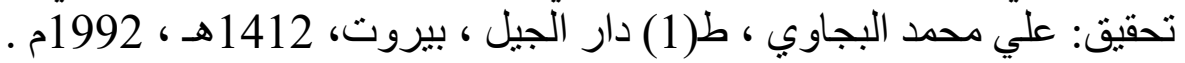

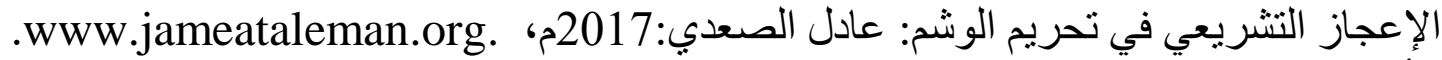

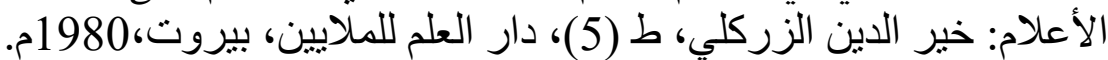

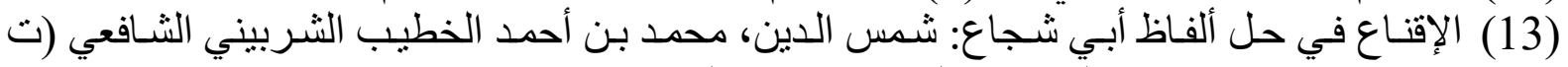

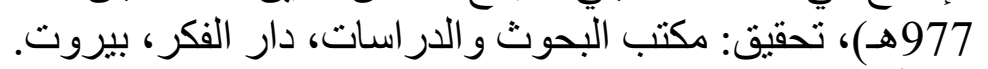

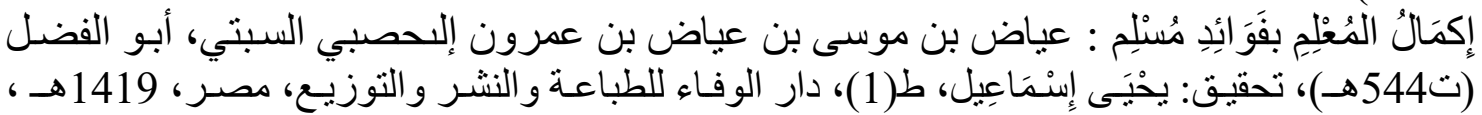
1998

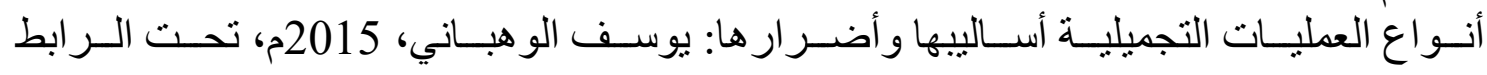

(16) البحر المحيط: محمد بن يوسف الثهير بأبي حيان الأندلسي (ت 754 هــ) حقيق: الثيخ عادل أحمد

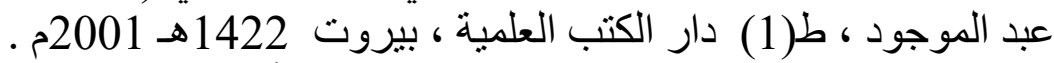

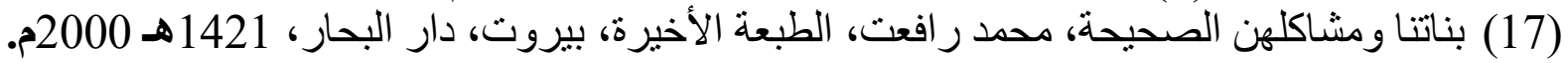

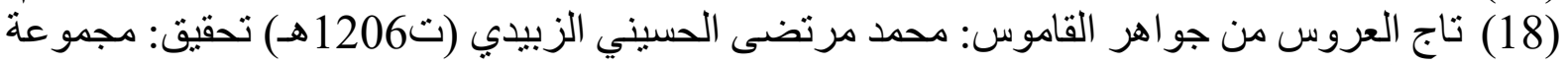

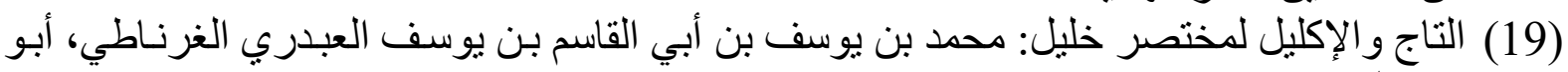

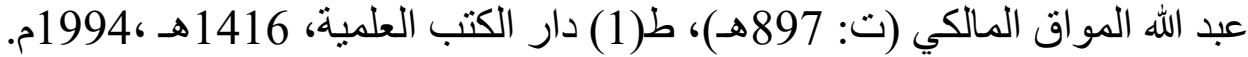

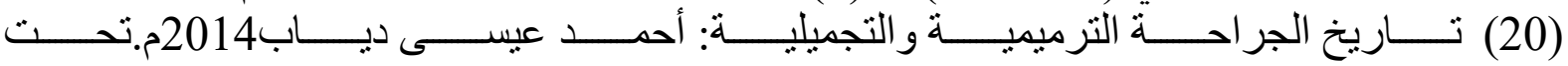

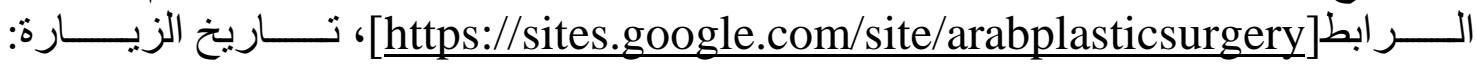


Proceeding of the $2^{\text {nd }}$ Scientific Conference on Women's Health 2-3 September 2020 - Hawler Medical University

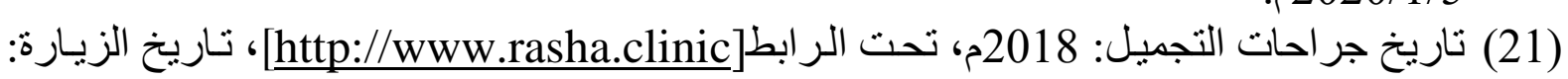
2020/1/5

(22) (29) تاريخ عمليات التجميل: 2018م، تحت الر ابط[1/5//tajmeeli.com]. 2020/1/5 (23) التحرير والتتوير : محمد الطاهر بن محمد بن محمد الطـاهر بن عاثشور التونسي (ت 1393هـ)،

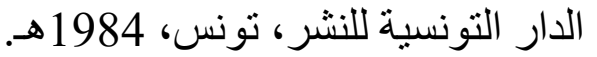
(24) تذكرة الحفـاظ: أبو عبد الله شمس الدين محمد الذهبي (ت 748 هـ) طـ(1) دار الكتب العلميـة،

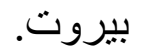
(25) جامع البيان في تأويل القرآن: أبو جعفر محمد بن جرير بن بزيد بن كثير الطبري (ت 310هـ)،

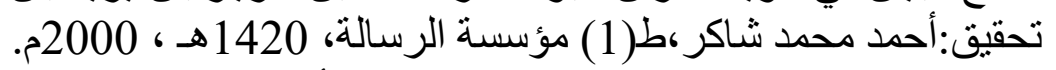

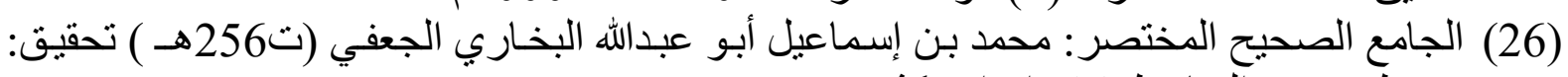

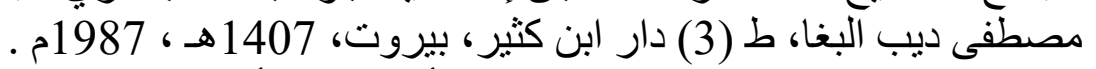

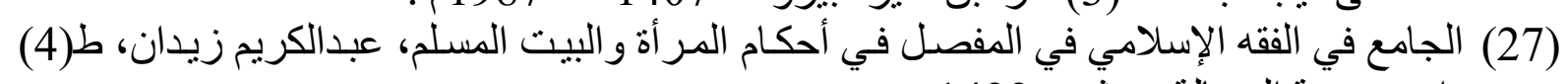

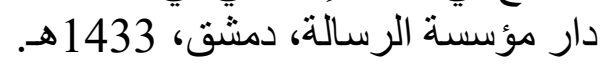

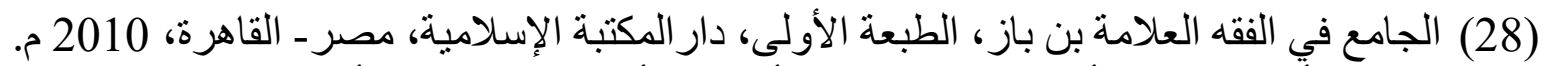

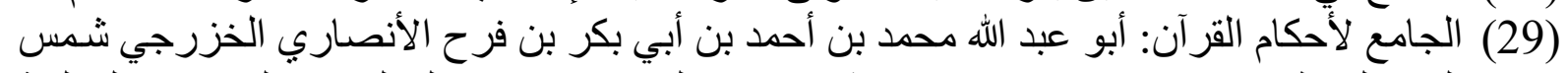

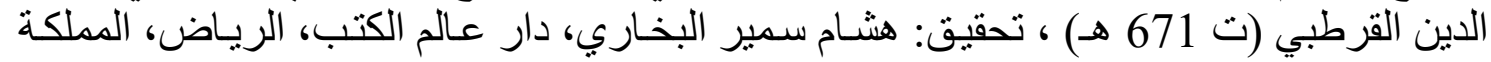

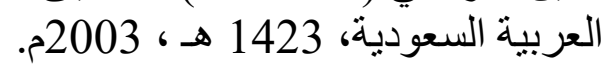
(30) الجر احسة التجميلية عرضية طرض طبي ودر اسـة فقهيـة منفصلة: صـالح بن محمد الفوزان، ط(1)، دار

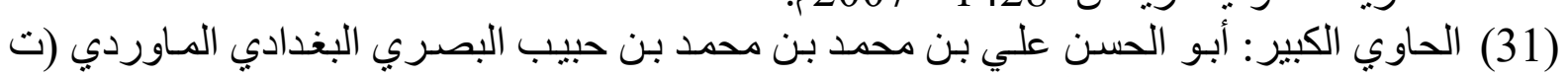

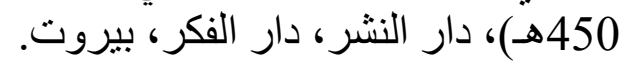

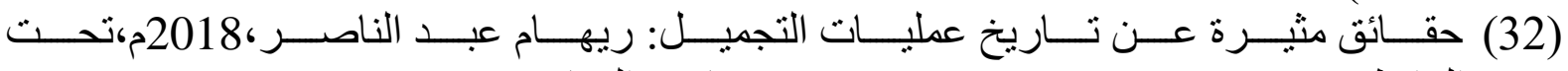

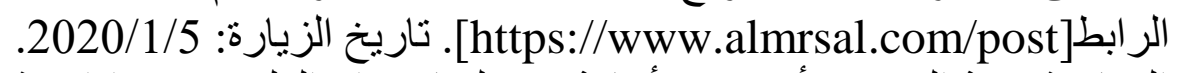

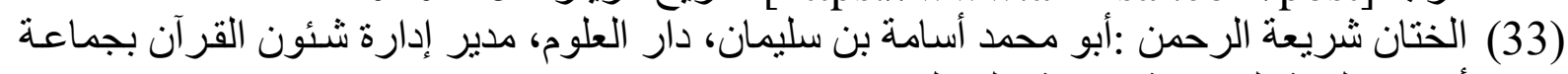

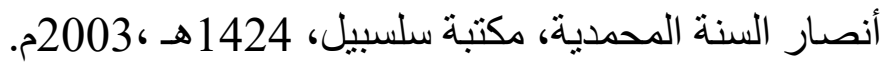
(34) دليل المر أة المسلمة: الثيخ عرفان العشـا حسون الدمشقى، مجموعة الثمة العلمـاء، دار الفكر، بيروت،

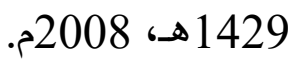

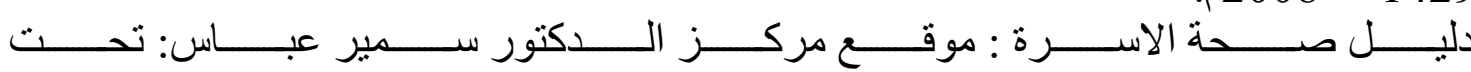

الر ابط] (36) دليل مكتبة المر أة المسلمة:أحمد بن عبد العزيز السليمان الحمدان: الكتاب منشور على موقع وزارة الأوقاف السعودية بدون بيانات. (37) ديوان الحطيئة: على موقع المكتبة الثاملة.

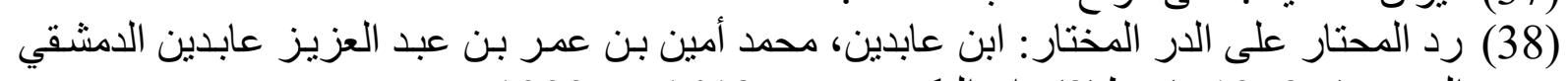

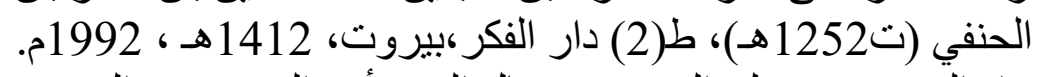

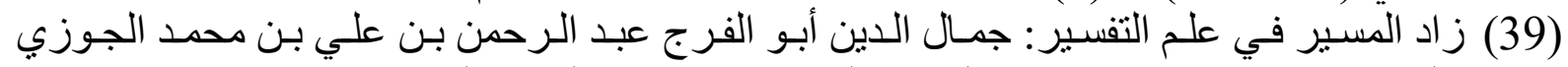

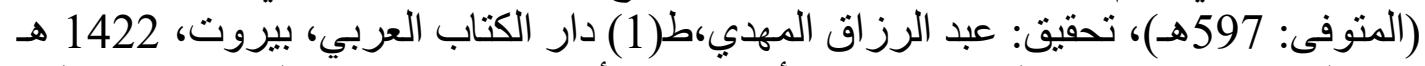

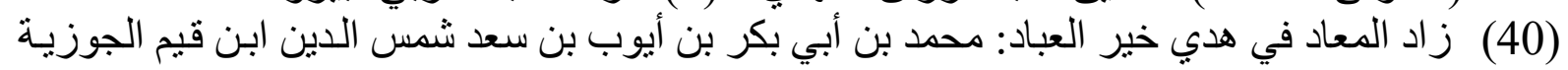

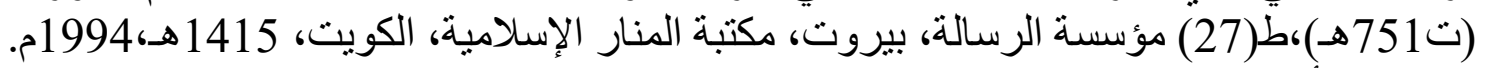

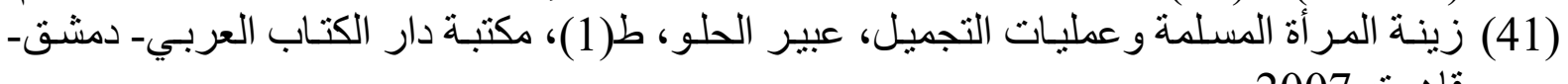

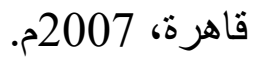


Proceeding of the $2^{\text {nd }}$ Scientific Conference on Women's Health 2-3 September 2020 - Hawler Medical University

(42) سنن ابن ماجة، أبي عبد الله محمد بن يزيد القزويني(ت 275هـ)، ط(1)، دار المعـارف، الريـاض، السعودية.

(43) سـنـ أبـي داود: أبـو داود سـليمان بـن الأشـعث بـن إسـحاق بـن بثـير بـن شـداد بـن عمرو الأزدي

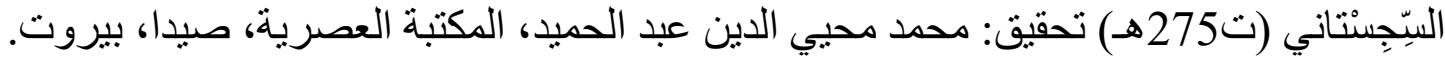
(44) سنن البيهقي الكبرى: أحمد بن الحسين بن علي بن موسى أبو بكر البيهقي (ت

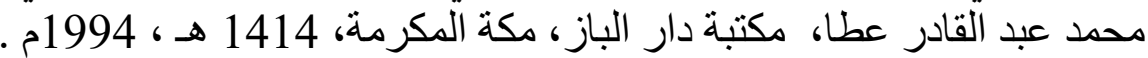

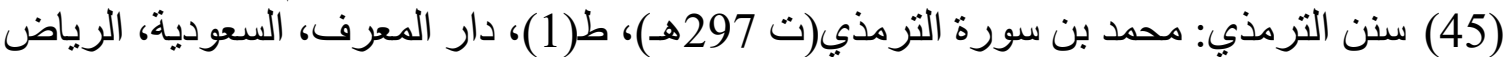

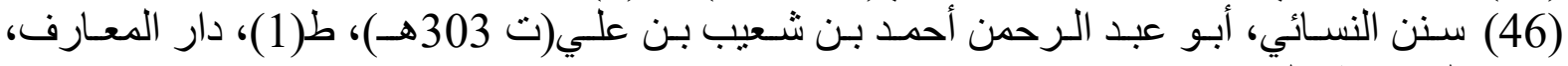

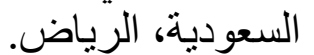

(47) شذر ات الذهب في أخبار من ذهب: عبد الحي بن أحمد عماد الدمشقي (ت1032 أرده) تحقيق: محمود

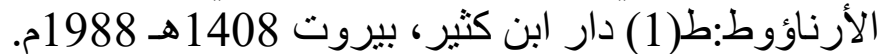

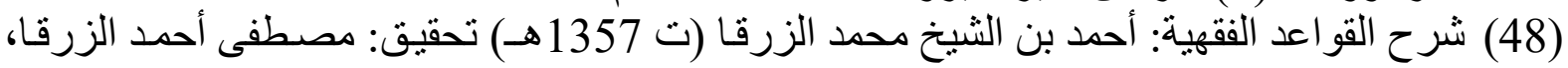

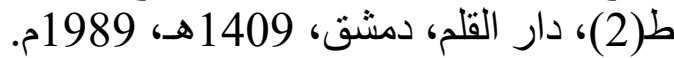

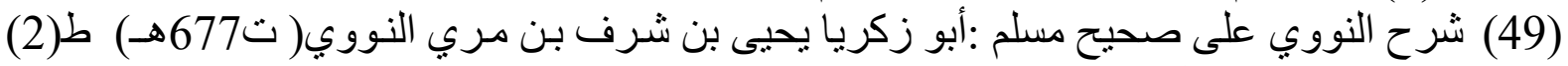

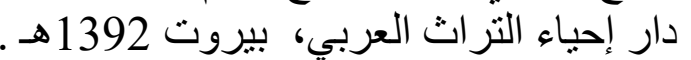
(50) شرح صحيح البخارى: ابن بطال أبو الحسن علي بن خلف خلف بن بن عبد الملك (ت 449هـ)، تحقيق: أبو

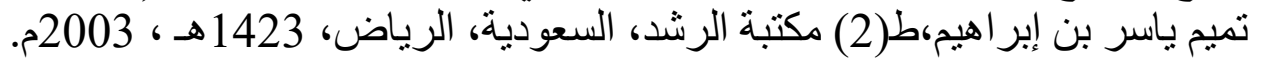

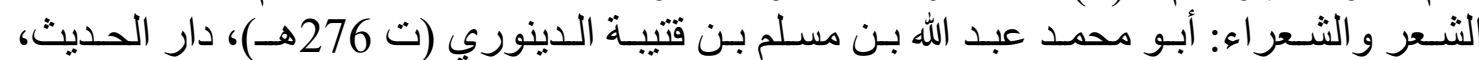
القاهرة، 1423 هـ. الصحاح في اللغة والعلوم: إسماعيل بن حماد الجوهري (ت393 3ـهـ) تقديم: عبد الله العلايلي،ط (1)

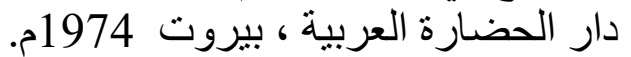

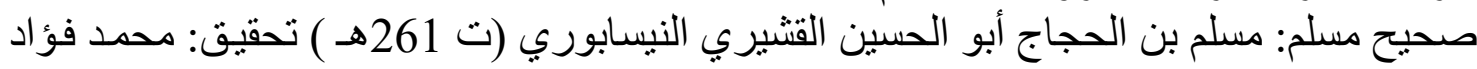
، دار إحياء التراث العربي، بيروت.

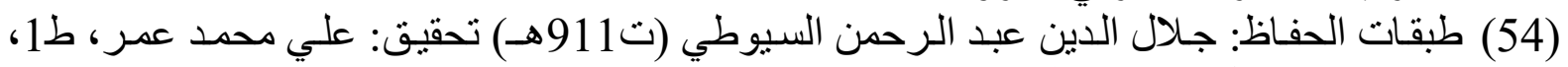

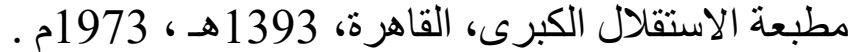

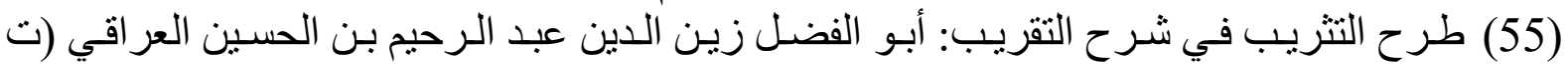

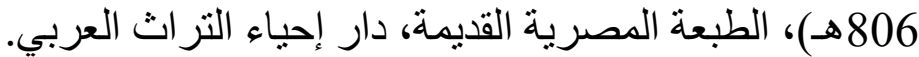

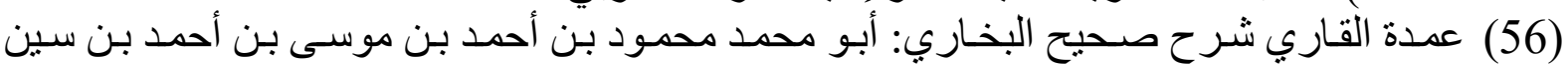
الغيتابى الحنفى بدر الدين العينى (ت:

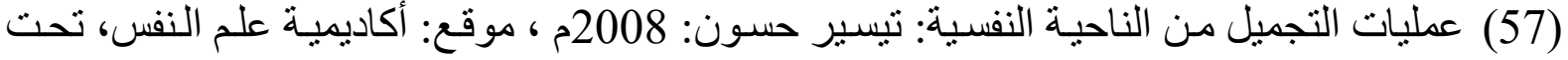
الر ابط:[https://acofps.com/vb.html]

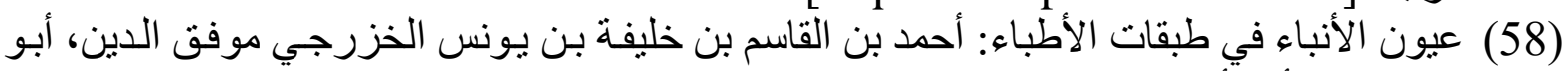

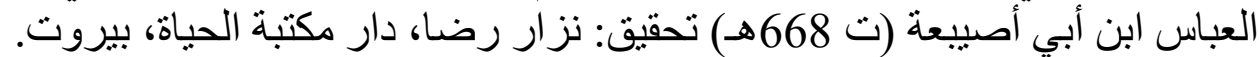
(59) الفتاوى الثرعية في المسائل الطبية: عبد الله بن عبد الرئ الرحمن الجبرين، جمعها و أعدها: إبر اهيم بن عبد العزيز الثشري، (على موقع المكتبة الثاملة).

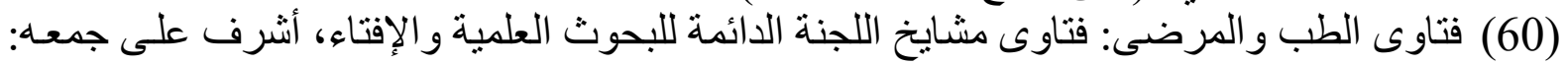

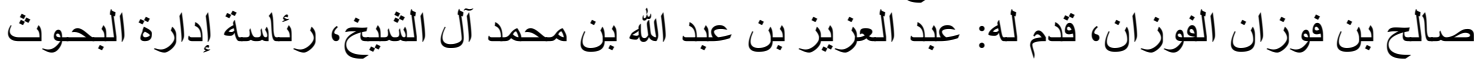

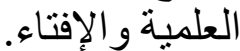

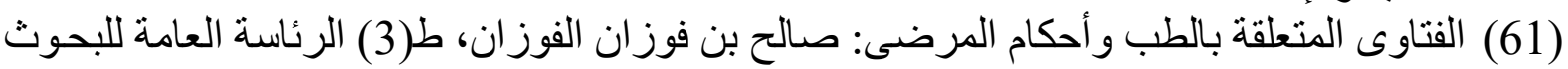

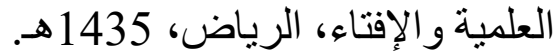

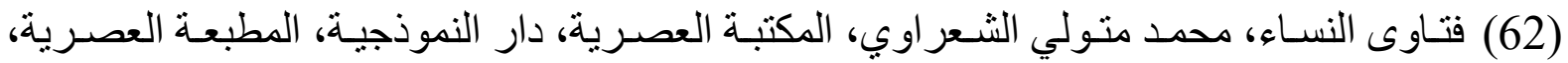


Proceeding of the $2^{\text {nd }}$ Scientific Conference on Women's Health 2-3 September 2020 - Hawler Medical University

(64) فتح الباري في شرح صحيح البخاري، للحافظ أحمد بن علي حجر العسقلاني، ط(3) ، دار السلام،

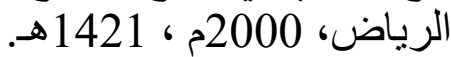
(65) الفروق (أنوار البروق في أنواء الفروق)، أبو العباس شهاب الدين أحمد بن إدريس بن عبد الرحمن

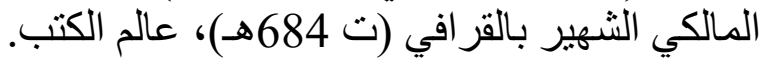
(66) القاموس المحيط، مجد الدين بن يعقوب الفيروز آبادي (ت 824 (820هـ)، دار الكتاب العربي، بيروت،

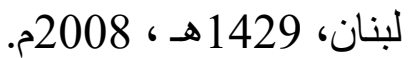
(67) قرار مجمع الفقه الإسلامي الدولي المنبثق عن منظمة المؤتمر الإسلامي المنعقد في دورتـه الثامنـة

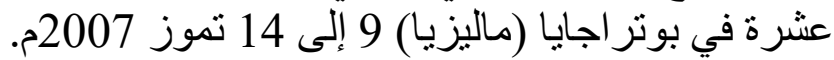

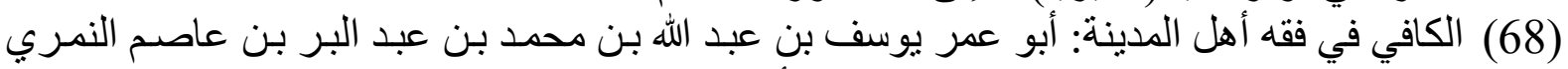

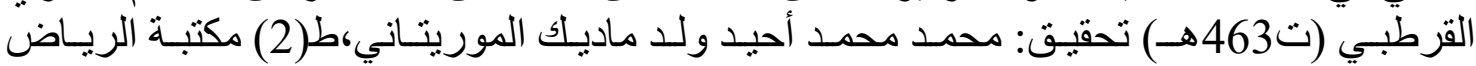

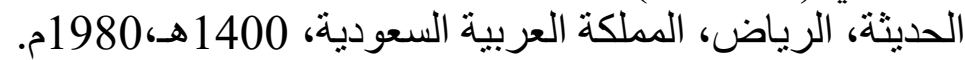

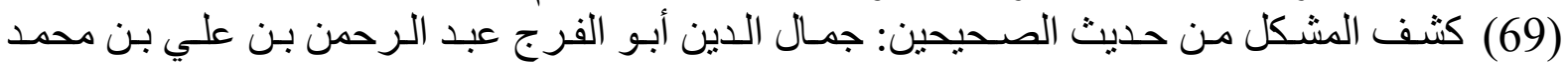

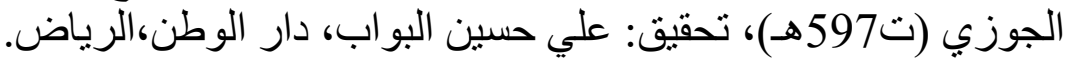

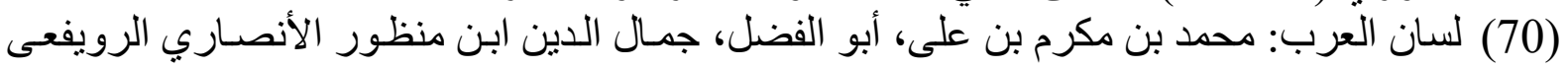

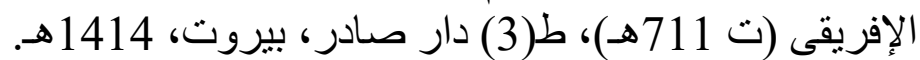

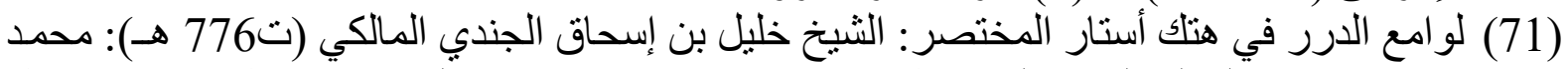

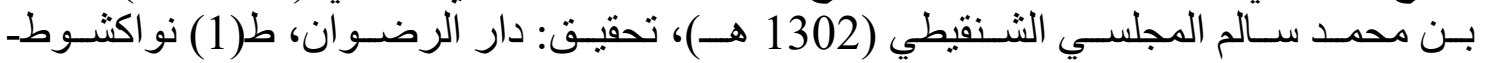

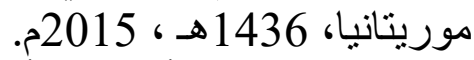

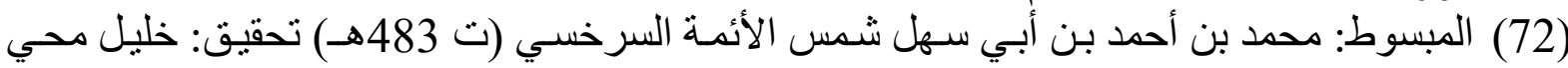

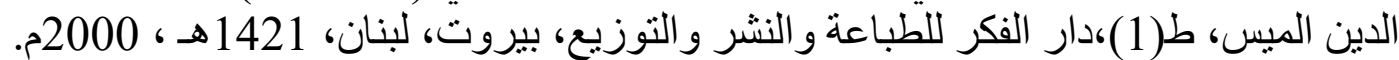

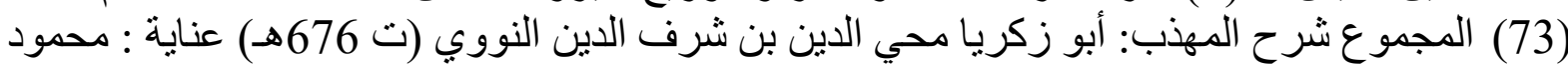

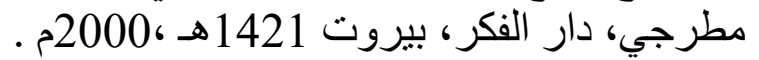
(74) مدى شرعية جر احة التجميل ومسؤولية الأطباء: أنور ابوبكر هو اني الجاف، دار الكتب القانونيـة، 2010م.

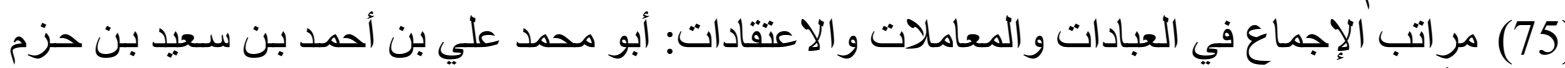

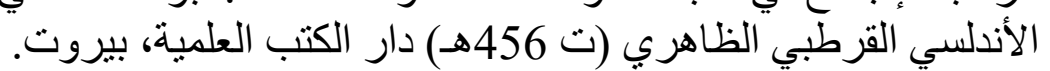

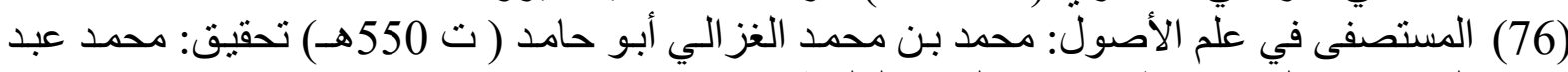

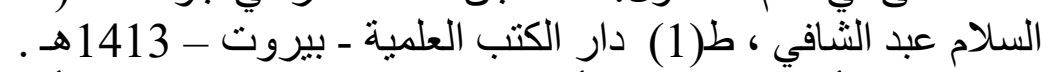

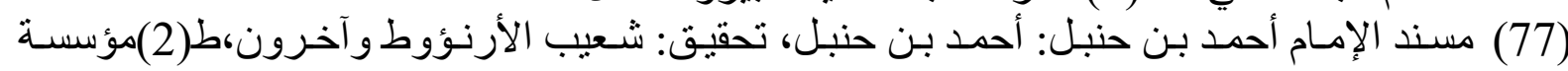

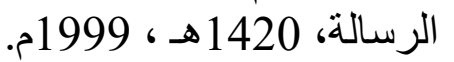
(78) معجم لغة الفقهاء: محمد رواس قلعجي، حامد ماهد صادق قنيبي، دار النفائس للطباعة و النشر و التوزيع،

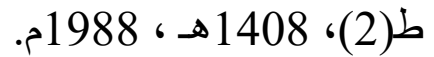

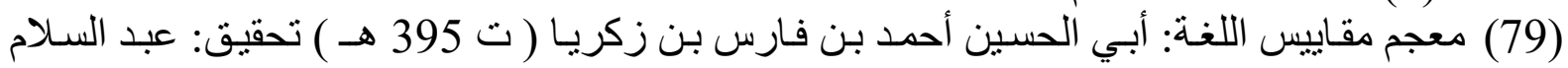

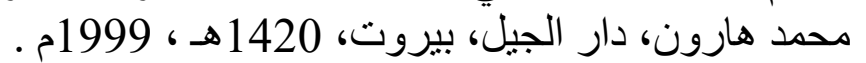
(80) المغني: أبو محمد موفق الدين عبد الله بن أحمد الحنبلي بن قدامـة المقدسي (ت 620هـ)، مكتبـة

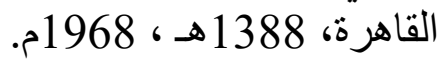

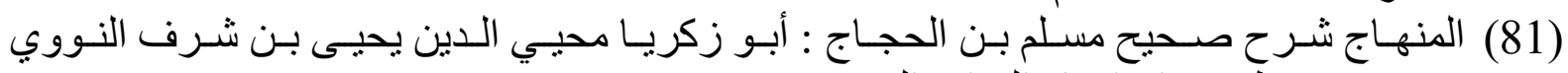

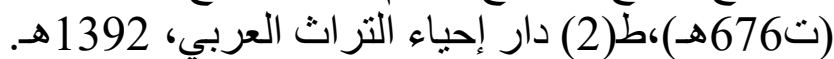
(82) الموسوعة الطبية الفقهية، دكتور أحمد محمد كنعان، طان(3)، دار النفائس، بيروت، لبنان، 1431هـ

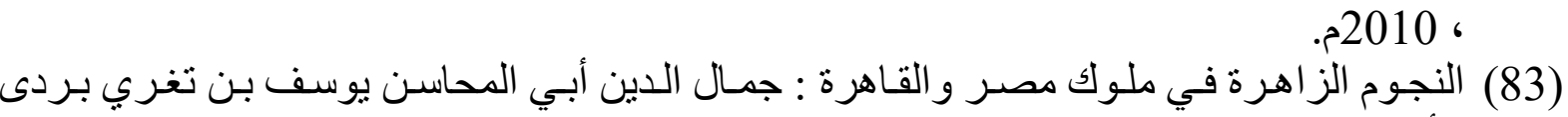

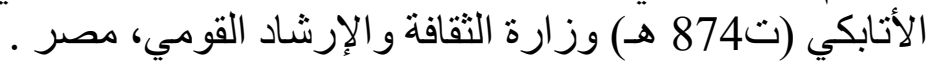

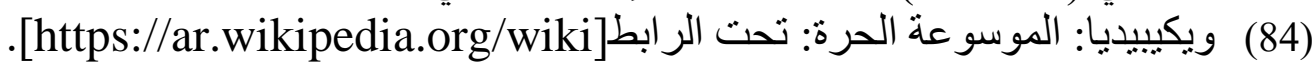

